Nevada

Environmental

Restoration

Project

DOE/NV-493

UC-700

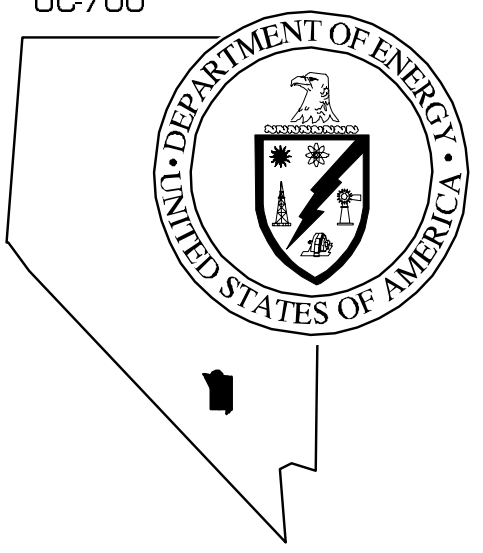

Resource Conservation and Recovery

Act Corrective Measures Study: Area 6

Decontamination Pond Facility,

Corrective Action Unit No. 92

Controlled Copy No::

Revision: 0

October 1997

Environmental Restoration

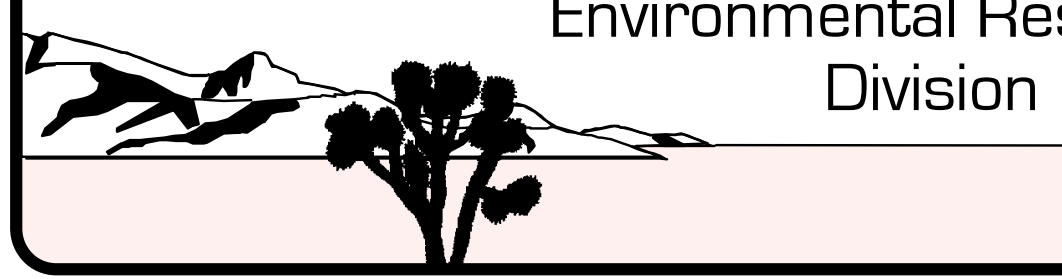




\title{
RESOURCE CONSERVATION AND RECOVERY ACT CORRECTIVE MEASURES STUDY: AREA 6 DECONTAMINATION POND FACILITY, CORRECTIVE ACTION UNIT NO. 92
}

\author{
DOE Nevada Operations Office
}

Las Vegas, Nevada

Controlled Copy No.:

Revision No: 0

October 1997 
This report has been reproduced directly from the best available copy.

Available to DOE and DOE contractors from the Office of Scientific and Technical Information, P.O. Box 62, Oak Ridge, TN 37831; prices available from (423) 576-8401.

Available to the public from the National Technical Information Service, U.S. Department of Commerce, 5285 Port Royal Rd., Springfield, VA 22161, telephone (703) 487-4650. 


\section{RESOURCE CONSERVATION AND RECOVERY ACT CORRECTIVE MEASURES STUDY: AREA 6 DECONTAMINATION POND FACILITY, CORRECTIVE ACTION UNIT NO. 92}

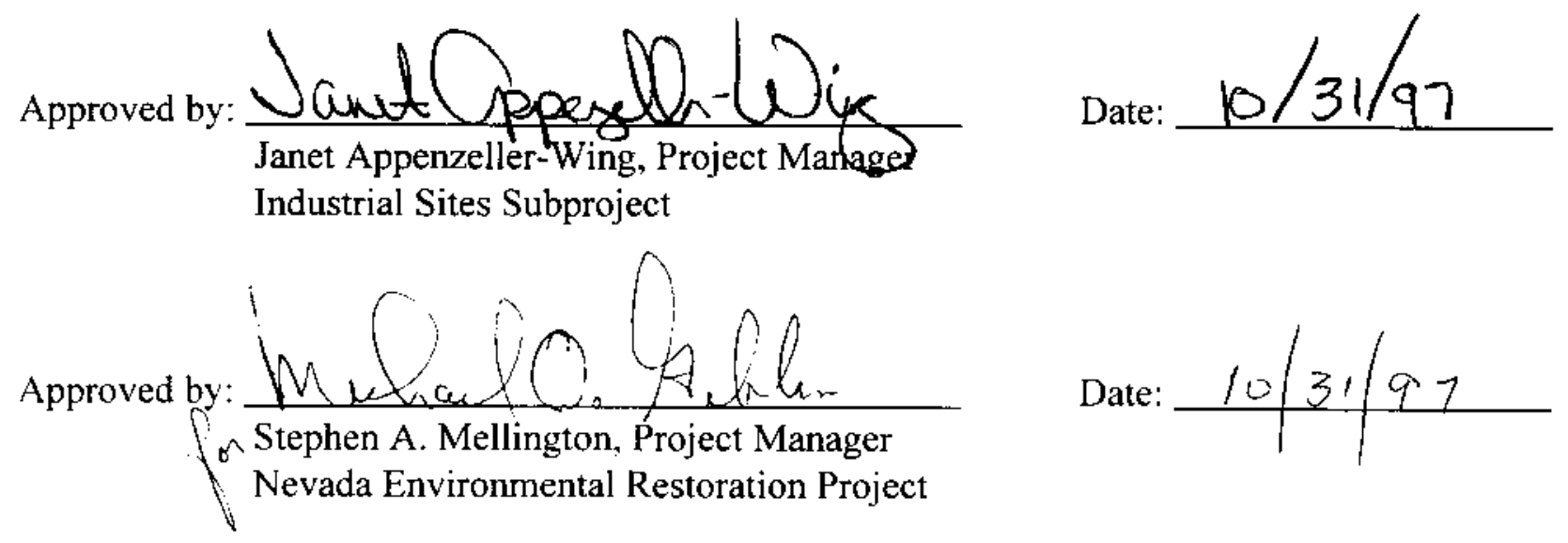




\section{Table of Contents}

List of Figures $\ldots \ldots \ldots \ldots \ldots \ldots \ldots \ldots \ldots \ldots \ldots \ldots \ldots \ldots \ldots \ldots \ldots \ldots$

List of Tables $\ldots \ldots \ldots \ldots \ldots \ldots \ldots \ldots \ldots \ldots \ldots \ldots \ldots \ldots \ldots \ldots \ldots \ldots$

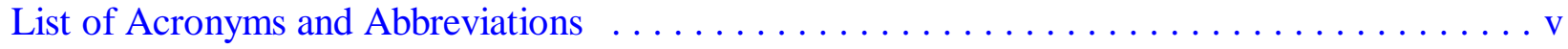

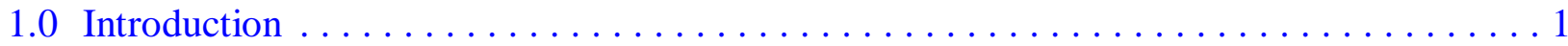

2.0 Characterization Summary $\ldots \ldots \ldots \ldots \ldots \ldots \ldots \ldots \ldots \ldots \ldots \ldots \ldots \ldots \ldots \ldots \ldots \ldots$

2.1 Characterization Activities and Results . . . . . . . . . . . . 6

2.2 Geotechnical/Hydrological Characterization Results $\ldots \ldots \ldots \ldots \ldots \ldots \ldots$

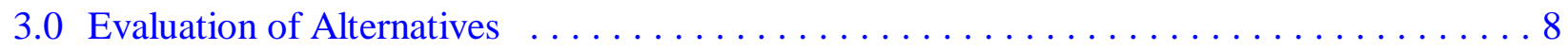

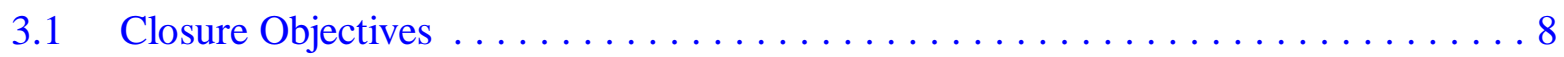

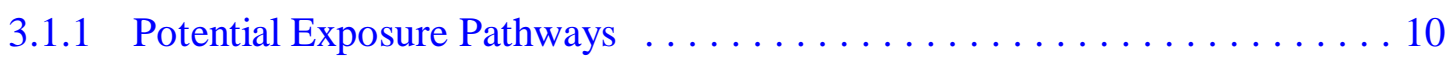

3.1.2 Risk and Dose Assessment Results . . . . . . . . . . . . 13

3.1.3 Media Cleanup Levels . . . . . . . . . . . . . . . . . . . . 14

3.2 Screening Criteria . . . . . . . . . . . . . . . . . . . 15

3.2.1 Closure Standards . . . . . . . . . . . . . . . . . . 16

3.2.2 Remedy Selection Decision Factors $\ldots \ldots \ldots \ldots \ldots \ldots \ldots \ldots$

3.3 Development of Closure Alternatives . . . . . . . . . . . . . . . . . 19

3.3.1 Alternative 1 - No Action . . . . . . . . . . . . . . . . . . . 19

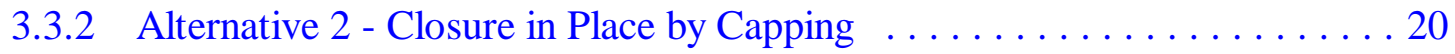

3.3.3 Alternative 3 - Clean Closure by Excavation and Disposal . . . . . . . . . 22

3.3.4 Alternative 4 - Closure in Place by Partial Excavation and Capping . . . . . 23

3.4 Detailed and Comparative Evaluation of Alternatives . . . . . . . . . . . 24

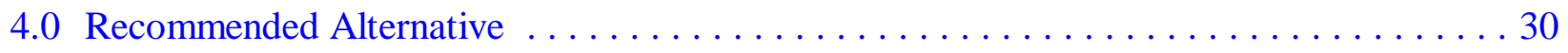

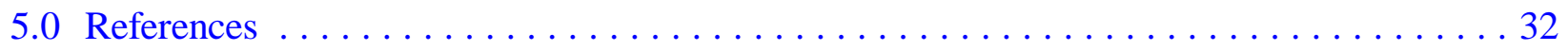


Page ii of $v$

\section{Table of Contents (Continued)}

Appendix A - Chemical Risk Assessment . . . . . . . . . . . . . . . . . A-1

Appendix B - Radiological Dose Assessment . . . . . . . . . . . . . . . . . . . . B-1

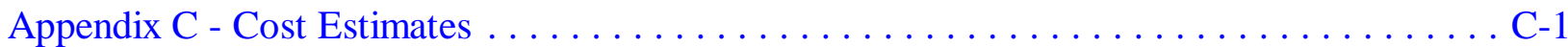




\section{List of Figures}

Number

Title

Page

1-1 Location of the Nevada Test Site $\ldots \ldots \ldots \ldots \ldots \ldots \ldots \ldots \ldots \ldots \ldots \ldots$

1-2 Location of the Area 6 Decontamination Pond Facility $\ldots \ldots \ldots \ldots \ldots \ldots$

1-3 Topographic Site Plan for the DPF .................... 


\section{List of Tables}

Number

Title

Page

3-1 Media Cleanup Standards and Contaminants of Concern . . . . . . . . . . . . 11

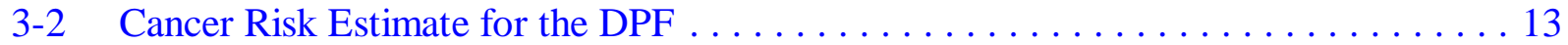

3-3 Noncancer Risk Estimate for the DPF . . . . . . . . . . . . . . . . . . . 14

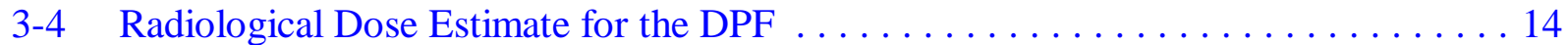

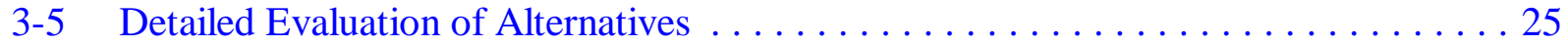

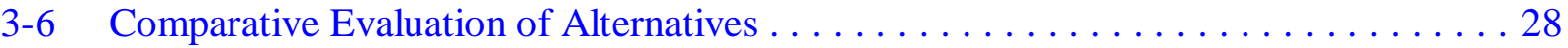




\section{List of Acronyms and Abbreviations}

$\begin{array}{ll}\text { BN } & \text { Bechtel Nevada } \\ \text { CAU } & \text { Corrective Action Unit } \\ \text { CFR } & \text { Code of Federal Regulations } \\ \mathrm{cm} / \mathrm{sec} & \text { Centimeter(s) per second } \\ \text { CMS } & \text { Corrective Measures Study } \\ \text { COC } & \text { Contaminant(s) of concern } \\ \text { COPC } & \text { Contaminant(s) of potential concern } \\ \text { DOE/NV } & \text { U.S. Department of Energy, Nevada Operations Office } \\ \text { DPF } & \text { Decontamination Pond Facility } \\ \text { EPA } & \text { U.S. Environmental Protection Agency } \\ \mathrm{ft} & \text { Foot (feet) } \\ \text { g/cm } & \\ \text { m } & \text { Gram per cubic centimeter } \\ \text { mg/kg } & \text { Meter(s) } \\ \text { mg/L } & \text { Milligram(s) per kilogram } \\ \text { mrem/yr } & \text { Milligram(s) per liter } \\ \text { NAC } & \text { Millirem(s) per year } \\ \text { NDEP } & \text { Nevada Administrative Code } \\ \text { NRS } & \text { Nevada Division of Environmental Protection } \\ \text { NTS } & \text { Nevada Revised Statutes } \\ \text { O\&M } & \text { Nevada Test Site } \\ \text { PCB } & \text { Operation and maintenance } \\ \text { PRG } & \text { Polychlorinated biphenyl(s) } \\ \text { RCRA } & \text { Preliminary remediation goals } \\ \text { TPH } & \text { Resource Conservation and Recovery Act } \\ & \text { Total petroleum hydrocarbon(s) } \\ & \end{array}$




\subsection{Introduction}

Corrective Action Unit (CAU) No. 92, the Area 6 Decontamination Pond Facility (DPF), is an historic disposal unit located at the Nevada Test Site (NTS) in Nye County, Nevada (Figures 1-1, 1-2, and 1-3). The NTS is operated by the U.S. Department of Energy, Nevada Operations Office (DOE/NV), which has been required by the Nevada Division of Environmental Protection (NDEP) to characterize the DPF under the requirements of the Resource Conservation and Recovery Act (RCRA) Part A Permit (NDEP, 1995) for the NTS and Title 40 Code of Federal Regulations (CFR) Part 265 (1996c). The DPF is prioritized in the Federal Facility Agreement and Consent Order (FFACO, 1996) but is governed by the permit.

The DPF was characterized through sampling events in 1994, 1996, and 1997. The results of these sampling events are contained in the Final Resource Conservation and Recovery Act Industrial Site Environmental Restoration Site Characterization Report, Area 6 Decontamination Pond Facility, Revision 1 (DOE/NV, 1997).

This Corrective Measures Study (CMS) for the Area 6 DPF has been prepared for the DOE/NV's Environmental Restoration Project. The CMS has been developed to support the preparation of a Closure Plan for the DPF. Because of the complexities of the contamination and regulatory issues associated with the DPF, DOE/NV determined a CMS would be beneficial to the evaluation and selection of a closure alternative.

The purpose of this CMS is to identify and provide a rationale for the selection of a recommended closure alternative based on the following factors:

- Level of risk

- Regulatory requirements

- Public/regulatory acceptance

- Protection of human health and the environment

- Compliance with media cleanup standards

- Control the sources of release

- Compliance with waste management standards

- Long-term reliability and effectiveness

- Reduction of toxicity, mobility, and volume

- Short-term reliability and effectiveness

- Feasibility

- Cost 


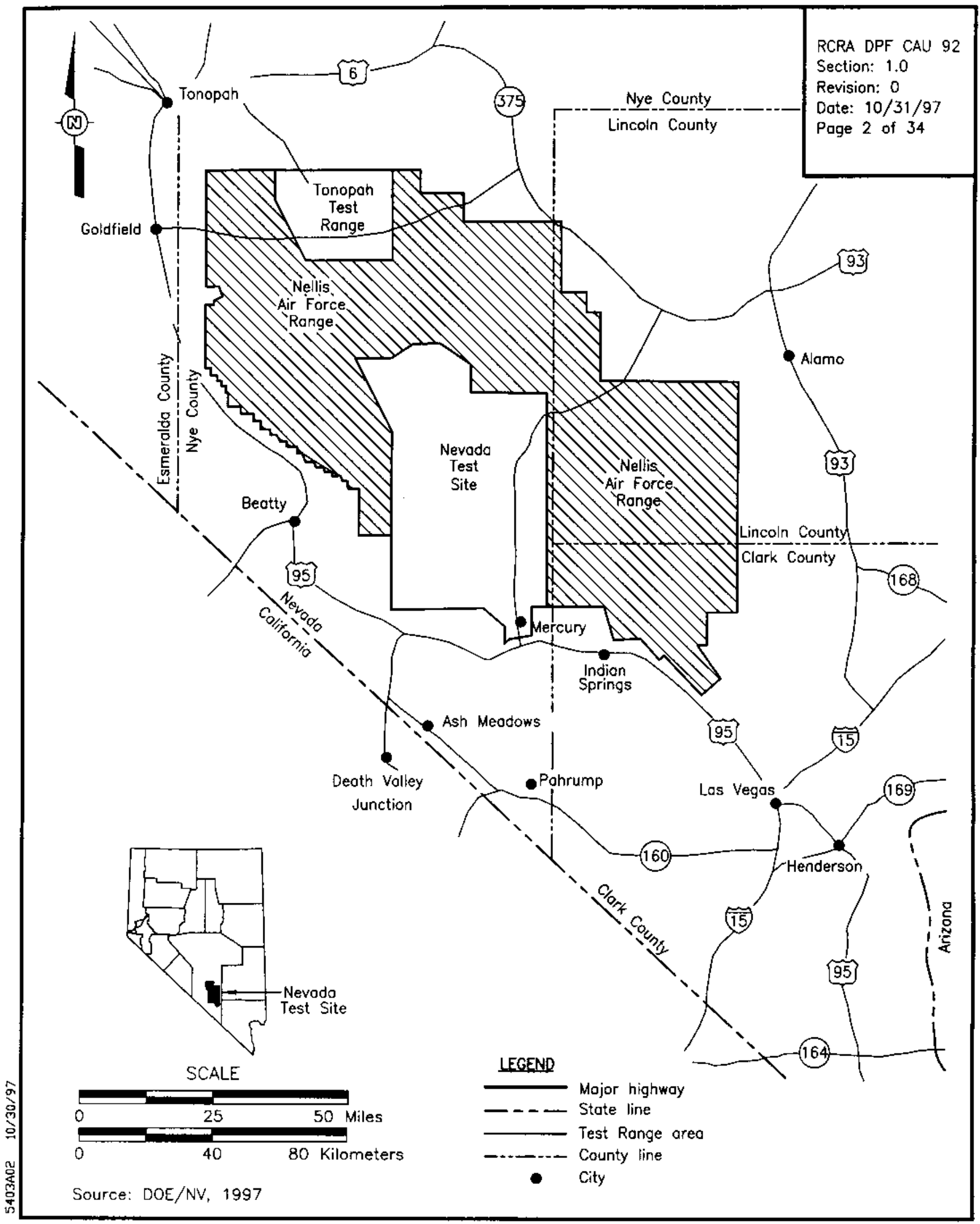

Figure 1-1

Location of the Nevada Test Site 

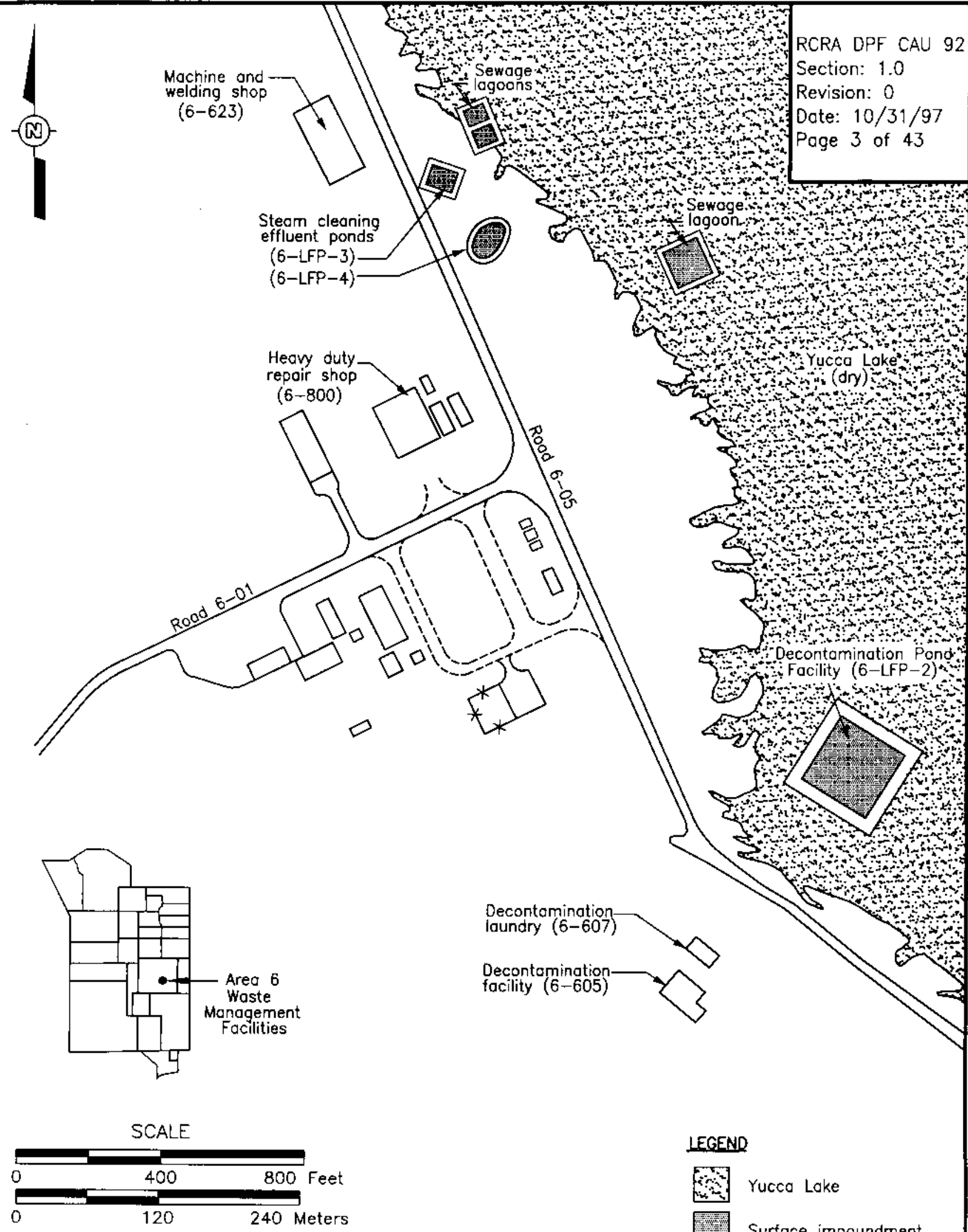

LEGEND

Yucca Lake

Source: DOE/NV, 1997

Surface impoundment 


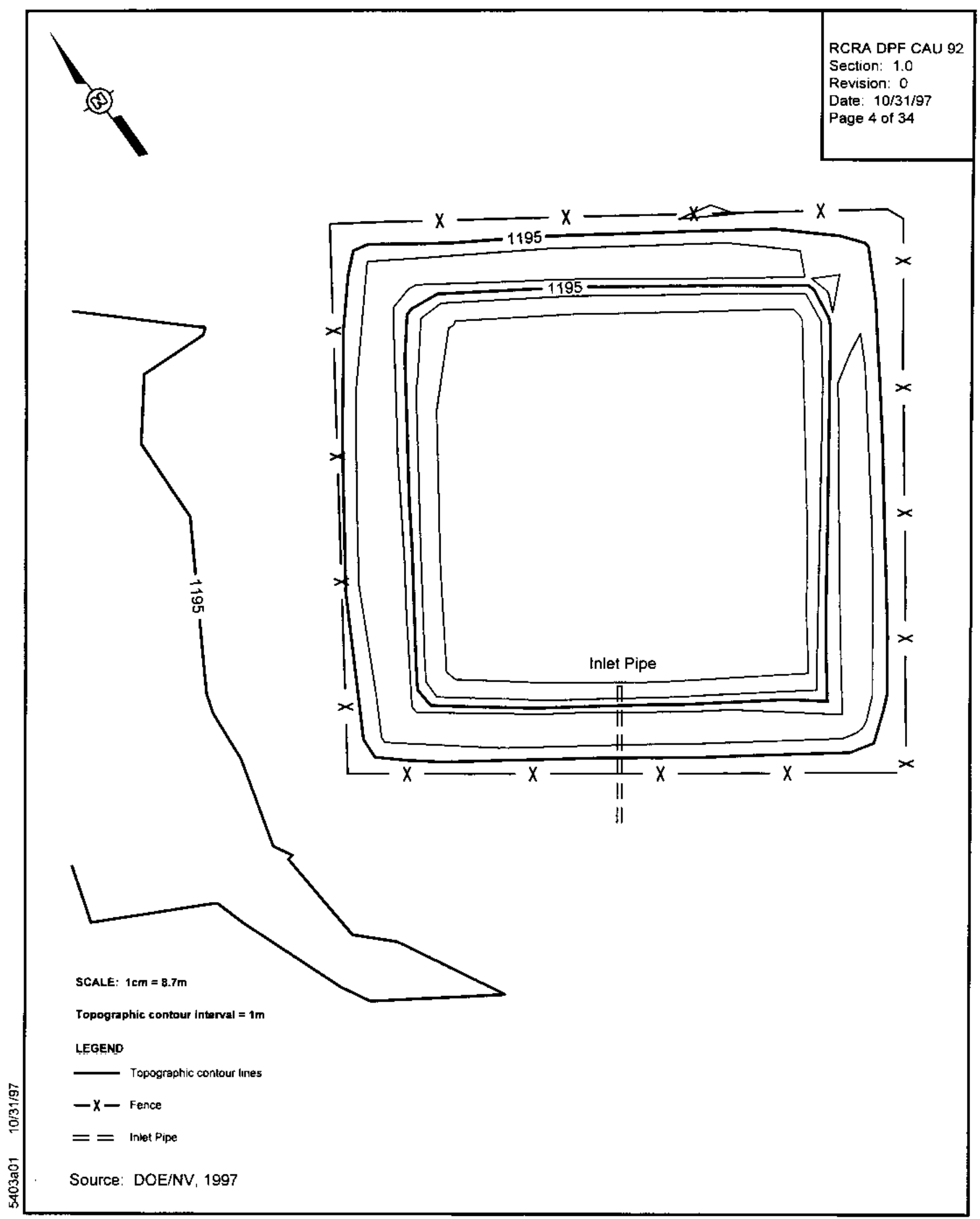

Figure 1-3

Topographic Site Plan for the DPF 
This CMS was developed using information and guidance provided in the following documents:

- Resource Conservation and Recovery Act Industrial Site Environmental Restoration Site Characterization Plan, Area 6 Decontamination Pond Facility, Revision 1 (DOE/NV, 1996e)

- Resource Conservation and Recovery Act Industrial Site Environmental Restoration Characterization Report, Area 6 Decontamination Pond Facility, Revision 1 (DOE/NV, 1997)

- Industrial Sites Quality Assurance Project Plan (DOE/NV, 1996b)

- Nevada Division of Environmental Protection Permit for a Hazardous Waste Management Facility, Nevada Test Site, NEV HW009 (NDEP, 1995)

- Project Management Plan (DOE/NV, 1994) 


\subsection{Characterization Summary}

\subsection{Characterization Activities and Results}

The characterization activities and sampling results for the DPF are presented in the Characterization Report (DOE/NV, 1997).

\subsection{Geotechnical/Hydrological Characterization Results}

The results of the geotechnical/hydrological characterization are presented in Characterization Report (DOE/NV, 1997). The parameters characterized support the evaluation of a range of closure options and are summarized in the following text:

- Particle size distribution of the DPF soils indicated a well-graded (poorly sorted) material ranging from small gravel to substantial quantities of fine silt and clay, typical of playa materials.

- The evaluation of dry bulk density indicated a difference in densities between the 0.3 -meters $(\mathrm{m})(1$-foot $[\mathrm{ft}])$ and $0.9-\mathrm{m}(3-\mathrm{ft})$ layers due to a change in layer properties from the near surface to the underlying playa sediments. The dry bulk density for the top $0.3 \mathrm{~m}$ ( $1 \mathrm{ft})$ of soil ranged from 1.21 to 1.52 grams per cubic centimeter $\left(\mathrm{g} / \mathrm{cm}^{3}\right)$ while they ranged from 1.05 to $1.44 \mathrm{~g} / \mathrm{cm}^{3}$ at $0.9-\mathrm{m}(3-\mathrm{ft})$ depth. The grain densities for the layers were identical, indicating the bimodal distribution in the dry bulk densities is a result of differentiation of either porosity or texture. The variation in the dry bulk density between the $0.3-\mathrm{m}(1-\mathrm{ft})$ and $0.9-\mathrm{m}(3-\mathrm{ft})$ layers is a result of biological activity and subsequent bio-plugging associated with the pond bottom materials.

- Results of the soil moisture content measurements were typical of fine-grained alluvial material.

- Porosities in the top $0.3-\mathrm{m}$ (1-ft) layer ranged from 0.387 to 0.542 while porosities in the $0.9-\mathrm{m}$ (3-ft) layer ranged from 0.481 to 0.538 . The change in soil porosity between these layers is indicative of the change in physical properties between these layers associated with the bio-plugging.

- Based on the measurements of saturated hydraulic conductivity, the top layer of the DPF

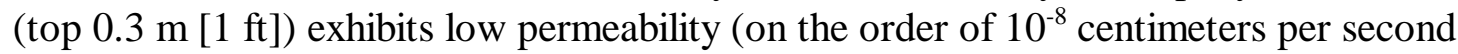
$[\mathrm{cm} / \mathrm{sec}])$ associated with biological activity and bio-plugging. The lower layer $(0.9 \mathrm{~m}$ [3 ft]) has a higher permeability (on the order of $10^{-5} \mathrm{~cm} / \mathrm{sec}$ ) associated with the absence of biological activity. This low-permeability top layer provides an almost impenetrable barrier to surface water infiltration.

As part of the evaluation of the geotechnical/hydrological characterization data, Bechtel Nevada $(\mathrm{BN})$ performed mathematical modeling to evaluate the potential for liquid migration at 
the DPF. The details of this modeling are presented in the characterization report (DOE/NV, 1997). The results are summarized below:

- Several precipitation and evaporation scenarios were evaluated to predict migration under current and worst-case conditions.

- Simulations predicted that the advancement of the water front was limited under all scenarios and that none of the scenarios would result in impacts to groundwater.

- Dissolved salts will not move as far as the water fronts because they move only in the liquid phase while water moves in both liquid and vapor phases.

- Organic molecules would be hindered by and would not readily pass through the biobarrier. Therefore, a large retardation time or irreversible sorption process would be expected for organic compounds.

- Most cationic species such as radionuclides are irreversibly sorbed by the zeolitic minerals in water and soil with high $\mathrm{pH}$, which is typical of the NTS playas.

- Under the worst-case scenario (original pond conditions and 100-year flood event), the wetting-front migration is less than $15 \mathrm{~m}(49 \mathrm{ft})$ after 100 years. According to this modeling, the natural conditions provide an adequate barrier to both infiltration and migration of contaminant of concern (COCs) at the DPF. Impacts to groundwater are not expected because groundwater depths in the vicinity of the DPF is $460 \mathrm{~m}$ to $500 \mathrm{~m}$ $(1,500 \mathrm{ft}$ to $1,600 \mathrm{ft})(\mathrm{DOE} / \mathrm{NV}, 1997)$. 


\subsection{Evaluation of Alternatives}

The purpose of this section is to present the closure objectives for the DPF, describe the general standards and decision factors used to screen the closure alternatives, and evaluate a set of closure alternatives that could be used to meet the closure objectives.

\subsection{Closure Objectives}

The objectives of the closure to be implemented at the DPF are to provide a remedy that protects human health and the environment, complies with requirements of the RCRA Part A permit (NDEP, 1995), complies with requirements for protecting "Waters of the State of Nevada," and complies with applicable waste management standards. In addition, the proposed closure option must be technically sound; cost-effective; and acceptable to DOE, NDEP, and the public.

Section V.A., "Historic RCRA Closure Units," of the RCRA permit (NDEP, 1995) requires that the DPF be closed subject to the conditions of 40 CFR 265.228, "Closure and Post-Closure Care" (CFR, 1996e). As specified in 40 CFR 265.228, the owner or operator must meet the following requirements at closure:

(1) Remove or decontaminate all waste residues, contaminated containment system components (liners, etc.), contaminated subsoils, and structures and equipment contaminated with waste and leachate, and manage them as hazardous waste; or

(2) Close the impoundment and provide post-closure care for a landfill under 40 CFR Subpart G and 40 CFR 265.310, including the following:

(i) Eliminate free liquids by removing liquid wastes or solidifying the remaining wastes and waste residue;

(ii) Stabilize remaining wastes to a bearing capacity sufficient to support the final cover; and

(iii) Cover the surface impoundment with a final cover designed and constructed to:

(A) Provide long-term minimization of the migration of liquids through the closed impoundment.

(B) Function with minimal maintenance.

(C) Promote drainage and minimize erosion or abrasion of the cover.

(D) Accommodate settling and subsidence so that the cover's integrity is maintained.

(E) Have a permeability less than or equal to the permeability of any bottom liner system or natural subsoils present." (CFR, 1996d and 1996f) 
Due to the low levels of COCs present in the DPF, including both hazardous and radioactive constituents, the relative risk associated with the facility is small (additional risk assessment information is provided in Appendices A and B). However, because of the presence of the chlorobenzene and other COCs in the surface and subsurface samples (see DOE/NV, 1997), the requirements for closure specified in the permit and referenced regulations must be met. The chlorobenzene is a listed waste per 40 CFR 261.31 (CFR, 1996b) based on its documented use and subsequent disposal as a solvent at the DPF. Therefore, clean closure of this unit would require removal of all chlorobenzene. This CMS includes the identification and evaluation of alternatives that will comply with these closure requirements while considering protection of human health and the environment.

The Nevada Revised Statute (NRS) 445A.415 (NRS, 1995a) defines "Waters of the State" as waters situated wholly or partly within or bordering upon this state, including but not limited to:

1. All streams, lakes, ponds, impounding reservoirs, marshes, water courses, waterways, wells, springs, irrigation systems, and drainage systems

2. All bodies or accumulations of water, surface and underground, natural or artificial Yucca Lake is generally a dry lake bed that experiences periods of flooding associated with meteorological events. Due to the location of the DPF in Yucca Lake, it has the potential to impact waters of the state. The groundwater impacts are limited as discussed in Section 2.2 and in the characterization report (DOE/NV, 1997). However, both surface and groundwater must be protected from degradation under Nevada Administrative Code (NAC) 445A.119 through 445A.213, "Standards for Water Quality," (NAC, 1995). In its current state, COCs from DPF could impact waters of the state through airborne or waterborne migration of contaminants. Closure alternatives are evaluated in this CMS for their ability to comply with "Waters of the State" and permit closure requirements.

The potential chemical COCs detected in the characterization are evaluated against media cleanup levels in Table 3-1. Based on this evaluation, the chemical COCs for the DPF are:

- Arsenic

- Chlorobenzene

- Bis(2-ethylhexyl)phthalate

- Lead

- $\mathrm{TPH}$ 
For the radionuclides, all those that exceed background concentrations are considered COCs for both the dose assessment and the detailed analysis of alternatives. The following radionuclides are considered COCs:

- Cobalt-60

- Strontium-90

- Cesium-137

- Lead-210

- Lead-212

- Radium-226

- Actinuim-228

- Thorium-234

- Plutonium-238

- Plutonium-239/240

- Americium-241

The closure alternatives are evaluated for their ability to address these COCs appropriately.

\subsubsection{Potential Exposure Pathways}

The Final Environmental Impact Statement for the Nevada Test Site and Off-Site Locations in the State of Nevada (DOE/NV, 1996a) identified the following land use options for Area 6:

- $\quad$ Reserved zone - areas and facilities that provide support for short-term testing and experimentation; also used for short-duration exercises and training

- Monitored and restricted zone - public access to the land is restricted

- Defense industrial zone - land area is designated for stockpile management of weapons 
Table 3-1

Media Cleanup Standards and Contaminants of Concern

(Page 1 of 2)

\begin{tabular}{|c|c|c|c|c|c|c|c|}
\hline COPC & $\begin{array}{c}\text { Maximum Total } \\
\text { Concentration } \\
(\mathrm{mg} / \mathrm{kg})\end{array}$ & $\begin{array}{c}\text { PRG } \\
\text { Residential } \\
(\mathrm{mg} / \mathrm{kg})^{\mathrm{a}} \\
\end{array}$ & $\begin{array}{c}\text { PRG } \\
\begin{array}{c}\text { Industrial } \\
(\mathrm{mg} / \mathrm{kg})^{\mathrm{b}}\end{array} \\
\end{array}$ & $\begin{array}{c}\text { RCRA Toxicity } \\
\text { Characteristic } \\
\text { Level } \\
(\mathrm{mg} / \mathrm{L})^{\mathrm{c}} \\
\end{array}$ & $\begin{array}{l}\text { Soil } \\
\text { Screening } \\
\text { Levels for } \\
\text { Ingestion } \\
(\mathrm{mg} / \mathrm{kg})^{\mathrm{d}} \\
\end{array}$ & $\operatorname{coc}^{e}$ & Notes \\
\hline \multicolumn{8}{|c|}{ Volatile Organic Compounds } \\
\hline Chlorobenzene & 0.079 & 65 & 220 & 100 & 1,600 & Yes & Listed waste $^{f}$ \\
\hline Xylene & 0.072 & 320 & 320 & NA & 410 & No & Below industrial $P R G^{g}$ \\
\hline \multicolumn{8}{|c|}{ Semivolatile Organic Compounds } \\
\hline Bis(2-ethylhexyl)phthlate & 240 & 32 & 140 & NA & 46 & Yes & Exceeds industrial PRG \\
\hline Butylbenzyl phthalate & 24 & 930 & 930 & NA & 16,000 & No & Below industrial $P R G^{g}$ \\
\hline di-N-octyl phthalate & 7.9 & 1,300 & 10,000 & NA & 1,600 & No & Below industrial $P R G^{g}$ \\
\hline Pyrene & 0.76 & 100 & 100 & NA & 2,300 & No & Below industrial $\mathrm{PRG}^{\mathrm{g}}$ \\
\hline \multicolumn{8}{|c|}{ Inorganics } \\
\hline Arsenic & 23.7 & 0.38 & 2.4 & NA & 0.4 & Yes & $\begin{array}{l}\text { Exceeds industrial PRG; no } \\
\text { background concentration } \\
\text { available for comparison }\end{array}$ \\
\hline Barium (total) & 1360 & 5,300 & 100,000 & NA & 5,500 & No & Below industrial $P R G^{g}$ \\
\hline Cadmium (total) & 14.9 & 38 & 850 & NA & 78 & No & Below industrial $P R G^{g}$ \\
\hline Chromium (total) & 44.8 & 210 & 450 & NA & 390 & No & Below industrial $\mathrm{PRG}^{\mathrm{g}}$ \\
\hline Lead (total) & 2170 & 400 & 1,000 & NA & 400 & Yes & Exceeds industrial PRG \\
\hline Mercury (total) & 0.19 & 6.5 & 68 & NA & NA & No & Below industrial $P R G^{g}$ \\
\hline Silver (total) & 2.8 & 380 & 8,500 & NA & 390 & No & Below industrial $P R G^{g}$ \\
\hline
\end{tabular}


Table 3-1

Media Cleanup Standards and Contaminants of Concern

(Page 2 of 2)

\begin{tabular}{|c|c|c|c|c|c|c|c|}
\hline COPC & $\begin{array}{c}\text { Maximum Total } \\
\text { Concentration } \\
(\mathrm{mg} / \mathrm{kg})\end{array}$ & $\begin{array}{c}\text { PRG } \\
\text { Residential } \\
(\mathrm{mg} / \mathrm{kg})^{\mathrm{a}} \\
\end{array}$ & $\begin{array}{c}\text { PRG } \\
\begin{array}{c}\text { Industrial } \\
(\mathrm{mg} / \mathrm{kg})^{\mathrm{b}}\end{array} \\
\end{array}$ & $\begin{array}{c}\text { RCRA Toxicity } \\
\text { Characteristic } \\
\text { Level } \\
(\mathrm{mg} / \mathrm{L})^{\mathrm{c}}\end{array}$ & $\begin{array}{c}\text { Soil } \\
\text { Screening } \\
\text { Levels for } \\
\text { Ingestion } \\
(\mathrm{mg} / \mathrm{kg})^{\mathrm{d}} \\
\end{array}$ & $\operatorname{coc}^{e}$ & Notes \\
\hline TPH & 21,000 & NA & NA & NA & NA & Yes & $>100 \mathrm{ppm}(\mathrm{NAC} 459.9973)^{\mathrm{h}}$ \\
\hline PCBs (Aroclor-1254) & 2.6 & 1.4 & 19 & NA & 1 & No & Below industrial PRG \\
\hline
\end{tabular}

${ }_{\mathrm{b}}^{\mathrm{a}}$ Residential Preliminary Remediation Goals (PRGs), EPA (1996a)

Industrial PRGs, EPA, (1996a); considered medial cleanup standards for the Decon Pond Facility based on land-use scenarios most likely for Area 6 of the Nevada Test Site 40 CFR 261.24 (CFR, 1996a)

EPA (1996b)

${ }_{\mathrm{f}}^{\mathrm{E}}$ Contaminant of concern

Below both residential and industrial PRGs

${ }^{9}$ Also below residential PRG

${ }^{\mathrm{h}}$ Nevada Administrative Code 459.9973 (NAC, 1990a)

NA $\quad=$ Not available

COPC = Contaminant of potential concern

$\mathrm{mg} / \mathrm{kg}=$ Milligram(s) per kilogram

$\mathrm{mg} / \mathrm{L}=$ Milligram(s) per liter

$\mathrm{COC}=$ Contaminant of concern 
This land use is consistent with that identified in the Record of Decision: Environmental Impact Statement for the Nevada Test Site and Off-Site Locations in the State of Nevada (DOE/NV 1996d), which prescribes a combination of the alternatives identified in the Environmental Impact Statement. This results in a combination of land-use scenarios for the area surrounding the DPF. However, the options do not include residential land use.

The exposure pathways considered include direct exposure, inhalation of radioactively contaminated airborne particles, inhalation of decay products from radon gas, and ingestion of soils. Exposure pathways are discussed in greater detail in Appendix B.

\subsubsection{Risk and Dose Assessment Results}

An assessment of risk associated with chemical COCs and of dose associated with radionuclides at the DPF was conducted as part of this CMS. The risk and dose were estimated under a no action scenario which assumes the COCs are not remediated in any way. The methodology, inputs, and results of the risk assessment are presented in Appendix A and for the dose assessment in Appendix B. Tables 3-2 and 3-3 summarize the chemical risks for the different scenarios. Table 3-4 summarizes the results of the dose assessment.

Table 3-2

Cancer Risk Estimate for the DPF

\begin{tabular}{||c|c|c||}
\hline \multirow{2}{*}{\multicolumn{1}{|c|}{ Pathway }} & \multicolumn{2}{|c|}{ Receptor } \\
\cline { 2 - 3 } & Radiological Worker & Industrial Worker \\
\hline \hline \multirow{2}{*}{ Ingestion } & $9 \times 10^{-8}$ & $4 \times 10^{-6}$ \\
\hline Inhalation & $4 \times 10^{-8}$ & $2 \times 10^{-6}$ \\
\hline Dermal & $1 \times 10^{-7}$ & $3 \times 10^{-6}$ \\
\hline \multicolumn{1}{|c|}{ TOTAL } & $3 \times 10^{-7}$ & $9 \times 10^{-6}$ \\
\hline
\end{tabular}

\footnotetext{
${ }^{\text {a }}$ Acceptable risk range is $10^{-6}$ to $10^{-4}$.
} 
Table 3-3

Noncancer Risk Estimate for the DPF

\begin{tabular}{||c|c|c||}
\hline \multirow{2}{*}{\multicolumn{1}{|c|}{ Pathway }} & \multicolumn{2}{|c||}{ Receptor } \\
\cline { 2 - 3 } & Radiological Worker & Industrial Worker \\
\hline \hline Ingestion & $7 \times 10^{-4}$ & $2 \times 10^{-2}$ \\
\hline Inhalation & $2 \times 10^{-5}$ & $8 \times 10^{-4}$ \\
\hline Dermal & $8 \times 10^{-4}$ & $3 \times 10^{-2}$ \\
\hline \multicolumn{1}{|c|}{ TOTAL } & $\mathbf{2 \times 1 0 ^ { - 3 }}$ & $\mathbf{5 \times 1 0 ^ { - 2 }}$ \\
\hline
\end{tabular}

${ }^{\mathrm{a}}$ Acceptable risk is less than 1.

Table 3-4

Radiological Dose Estimate for the DPF

\begin{tabular}{|c|c|c|c|c|}
\hline \multirow{3}{*}{$\begin{array}{l}\text { Time Post- } \\
\text { Closure } \\
\text { (years) }\end{array}$} & \multicolumn{4}{|c|}{$\begin{array}{l}\text { Total Effective Dose Equivalent } \\
\qquad(\mathrm{mrem} / \mathrm{yr})^{\mathrm{a}}\end{array}$} \\
\hline & \multicolumn{2}{|c|}{ No Action Alternative } & \multicolumn{2}{|c|}{ Engineered Cap Alternative } \\
\hline & $\begin{array}{c}\text { Hypothetical } \\
\text { Radiological } \\
\text { Worker }\end{array}$ & $\begin{array}{c}\text { Hypothetical } \\
\text { Industrial } \\
\text { Worker }\end{array}$ & $\begin{array}{c}\text { Hypothetical } \\
\text { Radiological } \\
\text { Worker }\end{array}$ & $\begin{array}{c}\text { Hypothetical } \\
\text { Industrial } \\
\text { Worker }\end{array}$ \\
\hline 0 to 10 & 0.92 to 0.3 & NA & $<0.0001$ & NA \\
\hline 10 to 30 & 0.3 to 0.077 & 86.7 to 49.3 & $<0.0001$ & 15.8 to 16.0 \\
\hline 30 to 100 & 0.077 to 0.041 & 49.3 to 46.6 & $<0.0001$ & 16.0 to 16.4 \\
\hline$>100$ & 0.03 to 0.064 & 46.6 to 69.4 & 0 to 0.032 & 16.4 to 42.7 \\
\hline
\end{tabular}

${ }^{\mathrm{a}}$ Dose limit is less than 100 millirems per year.

$\mathrm{NA}=$ Not assessed

\subsubsection{Media Cleanup Levels}

Media cleanup levels are identified in Table 3-1. Preliminary remediation goals (PRGs) are identified as cleanup levels. The PRGs in Table 3-1 are from the U.S. Environmental Protection Agency (EPA) Region IX 1996 PRG tables under the residential and industrial land-use scenarios (EPA, 1996a). The maximum concentrations for the COCs are evaluated against the

PRGs and against the soil screening levels from EPA's Soil Screening Guidance: User's Guide (EPA, 1996b). The land-use identified in the EIS for the area surrounding the DPF is, at worstcase, industrial. Therefore, the industrial PRGs are used to define cleanup levels. For TPH, the media cleanup level is 100 milligrams per kilogram $(\mathrm{mg} / \mathrm{kg})$ as identified in the NAC 459.9973 
(NAC, 1990a). For radionuclides, the cleanup level corresponds to a dose limit of 100 millirems per year (mrem/yr) as specified in DOE Order 5400.5 (DOE, 1993).

\subsection{Screening Criteria}

The screening criteria used to evaluate and select the closure alternatives consisted of closure standards and remedy selection decision factors described in the EPA guidance documents Guidance on Resource Conservation and Recovery Act Corrective Action Decision Documents (EPA, 1991) and the Final Resource Conservation and Recovery Act Corrective Action Plan (EPA, 1994).

The closure alternatives delineated in Section 3.3 are evaluated based on four closure standards and five remedy selection decision factors, as described in the following text. All closure alternatives must meet the general closure standards to be selected for evaluation using the remedy selection decision factors.

The closure standards are as follows:

- Protection of human health and the environment

- Compliance with media cleanup standards

- Control the source(s) of the release

- Comply with applicable federal, state, and local standards for waste management

The remedy selection decision factors are:

- Short-term reliability and effectiveness

- Reduction of toxicity, mobility, and/or volume

- Long-term reliability and effectiveness

- Feasibility

- Cost

The corrective action standards and remedy selection decision factors are described in further detail in the following subsections.

\subsubsection{Closure Standards}

The following describe the closure standards used to evaluate the closure alternatives: 


\section{Protection of Human Health and the Environment}

Protection of human health and the environment is a general mandate of the RCRA statute (EPA, 1994). This mandate requires that the closure option include any measures that are needed to be protective. These measures may or may not be directly related to media cleanup, source control, or management of wastes. The closure option is evaluated for the ability to meet closure objectives as defined in Section 3.1. Ability of a closure option to protect "Waters of the State" is also evaluated.

\section{Compliance with Media Cleanup Standards}

Each closure alternative must have the ability to meet the proposed media cleanup standards and to comply with the following state and federal requirements:

- 40 CFR 265.228 (CFR, 1996e) - regulations governing closure of surface improvements

- NAC 445A.119 through 445A.213 (NAC, 1995) - regulations governing protection of waters of the state

\section{Control the Source(s) of the Release}

An objective of the closure is to stop further environmental degradation by controlling or eliminating additional releases that may pose a threat to human health and the environment. Unless source control measures are taken, efforts to clean up releases may be ineffective or, at best, would essentially involve a perpetual cleanup. Therefore, each closure alternative must use an effective source control program to ensure the long-term effectiveness and protectiveness of the closure effort.

\section{Comply with Applicable Federal, State, and Local Standards for Waste Management}

During implementation of any closure alternative, all waste management activities must be conducted in accordance with all applicable state and federal regulations (e.g., Nevada Revised Statutes 459.400 - 459.600 [NRS, 1995b], RCRA 40 CFR 261-281 [CFR, 1996h], 40 CFR 268, "Land Disposal Restrictions," [CFR, 1996g] NAC 459.9974 "Disposal and Evaluation of Contaminated Soil," [NAC, 1990b] and NTS Waste Acceptance Criteria [DOE/NV, 1996c]). The requirements for management of the wastes, if any, derived from the closure activities will be determined based on the regulatory requirements listed above, field observations, process knowledge, characterization data, and data collected and analyzed during closure. Administrative controls (e.g., decontamination procedures and closure strategies) will minimize waste generated during site closure activities. Decontamination activities will be performed in accordance with approved procedures and will be designated according to the COCs present at the site. 


\subsubsection{Remedy Selection Decision Factors}

The following describe the remedy selection decision factors used to evaluate the closure alternatives:

\section{Short-Term Reliability and Effectiveness}

Each closure alternative is evaluated with respect to its effects on human health and the environment during the construction and implementation phases of the closure. The following factors will be addressed for each alternative:

- Protection of the community to address any risk that results from implementation, such as fugitive dusts, transportation of hazardous materials, or air-quality impacts from off-gas emissions

- Protection of workers during construction and implementation

- Environmental impacts which may result from construction and implementation

- The amount of time until closure objectives are achieved

\section{Reduction of Toxicity, Mobility, and/or Volume}

Each closure alternative is evaluated for its ability to reduce the toxicity, mobility, and/or volume of the contaminated media. Reduction in toxicity, mobility, and/or volume refers to changes in one or more characteristics of the contaminated media by the use of corrective measures that decrease the inherent threats associated with the media.

\section{Long-Term Reliability and Effectiveness}

Each closure alternative is evaluated in terms of the risk remaining at the site after closure alternatives have been met. The primary focus of this evaluation will be on the extent and effectiveness of the controls that may be required to manage risk posed by treatment residuals and/or untreated wastes.

\section{Feasibility}

This criterion addresses the technical and administrative feasibility of implementing a closure alternative and the availability of various services and materials needed during implementation. Each closure alternative must be evaluated for the following criteria: 
- Construction and Operation: This refers to the feasibility of implementing a closure alternative given the existing set of waste and site-specific conditions.

- Administrative Feasibility: This refers to the administrative activities needed to implement the closure alternative (e.g., permits, public acceptance, rights-of-way, off-site approval).

- Availability of Services and Materials: This refers to the availability of adequate off-site and on-site treatment, storage capacity, disposal services, needed technical services and materials, and availability of prospective technologies for each closure alternative.

\section{Cost}

The cost estimate for each closure alternative includes both capital and operation and maintenance $(\mathrm{O} \& \mathrm{M})$ costs, if applicable. A brief description of both components of these costs is as follows:

- Capital Costs: These costs include both direct and indirect costs. Direct costs may consist of materials, labor, mobilization, demobilization, site preparation, construction materials, equipment purchase and rental, sampling and analysis, waste disposal, and health and safety measures. Indirect costs include such items as engineering design, permits and/or fees, start-up costs, and any contingency allowances.

- Operation and Maintenance: These costs include labor, training, sampling and analysis, maintenance materials, utilities, and health and safety measures.

A net present worth is calculated for each closure alternative if long-term O\&M is required. For purposes of this CMS, an O\&M period of 10 years is assumed for all alternatives requiring O\&M activities. This time frame is consistent with other CAUs that have post-closure monitoring requirements. Cost estimates were developed by $\mathrm{BN}$; details of the cost estimates are presented in Appendix C.

\subsection{Development of Closure Alternatives}

Based on the review of existing data and the requirements of the RCRA permit, the following alternatives have been developed for consideration as closure options at the DPF:

- Alternative 1 - No Action

- Alternative 2 - Closure in Place by Capping

- Alternative 3 - Clean Closure by Excavation and Disposal

- Alternative 4 - Closure in Place by Partial Excavation and Capping 
An overview of these alternatives is presented in the following text. Based on the modeling conducted by $\mathrm{BN}$, the natural soil materials of the pond provide an effective barrier to the infiltration of liquids and the downward migration of COCs (see DOE/NV, 1997). Therefore, as a baseline, all the alternatives are considered protective of groundwater.

\subsubsection{Alternative 1 - No Action}

The no action alternative serves as a baseline for comparison to other alternatives. The no action alternative does not include any closure elements. However, as part of this alternative, some maintenance and monitoring would be conducted. The recent characterization activities have disturbed the existing soil cement. Under the no action alternative, the soil cement may be reapplied to the entire interior of the DPF, including the berms, to control the spread of radiologically contaminated dust. Because surface contamination is present at the DPF, monitoring to determine potential spread of contaminants would be conducted during times of adverse conditions such as wind and rain storms. These maintenance and monitoring activities are the only costs associated with Alternative 1. The baseline risks and doses associated with the no action alternative are summarized in Tables 3-2 through 3-4. This alternative is used as a baseline for comparison with the other alternatives. Based on the risk assessment, the risk associated with the no action alternative is low and well within target ranges for both carcinogens and noncarcinogens (see Tables 3-2, 3-3, and Appendix A). The dose assessment showed that the dose under each of the evaluated scenarios is below the $100 \mathrm{mrem} / \mathrm{yr}$ DOE limit for protection of the public from DOE activities (see Table 3-4 and Appendix B).

While the alternative is easily implementable and has low short-term risk to workers, it does not meet the RCRA permit requirements for closure of the DPF. Therefore, this alternative will not be evaluated using the remedy selection decision factors in the detailed analysis.

\subsubsection{Alternative 2 - Closure in Place by Capping}

Alternative 2 uses a cap placed over the DPF to prevent intrusion into the waste, to minimize infiltration of water to the waste, to prevent access to radioactive contaminants while they decay over time, and to protect "Waters of the State of Nevada." Capping can range from simple compacted native soils to more highly engineered caps consisting of several layers of different types and sizes of materials. 
Based on the evaluation of geotechnical data as reported in the characterization report (DOE/NV, 1997), the permeability of the contaminated zone is on the order of $10^{-8} \mathrm{~cm} / \mathrm{sec}$ for the upper $0.3 \mathrm{~m}(1.0 \mathrm{ft})$ of the DPF and $10^{-5} \mathrm{~cm} / \mathrm{sec}$ below this depth. Results of the study indicate that the biological plugging of the surface material has created a low permeability zone in the top layer of the DPF. This bio-layer is the result of disposal activities and is not representative of natural subsoils. Therefore, the $10^{-5} \mathrm{~cm} / \mathrm{sec}$ permeability is considered representative and the basis for the cap design to meet closure requirements. According to the requirements in $40 \mathrm{CFR}$ 265.228, "Closure and Post-Closure Care" (CFR, 1996e), the cap must have a permeability less than or equal to the permeability of the natural subsoils present.

Native soils located in the playa are thought to be suitable for use as cap materials. The soils are located proximally to the DPF and are anticipated to be compactable to a permeability between $1 \times 10^{-7}$ and $1 \times 10^{-5} \mathrm{~cm} / \mathrm{sec}$. (Sampling and testing have been conducted by BN to support this assumption; however, the analysis was not available for inclusion in this document. It will be included in the closure plan.) A test cap section may be constructed from the potential capping materials to evaluate construction and performance parameters prior to actual cap construction at the DPF. If the native soils are not acceptable (i.e., do not meet the performance standards specified in 40 CFR 265.228 for closure [CFR, 1996e]), then other materials will need to be identified and tested, such as native materials from another NTS location, or other construction materials such as asphalt or cement.

The cap will be designed to minimize run-on, run-off, and erosion. Due to the potential for flooding of the site during heavy rainstorms, the cap will be subject to repeated wet and dry cycles. The cap material should be able to withstand these cycles without significant desiccation or cracking. The cap will be constructed to protect "Waters of the State of Nevada" from contacting the COCs.

Alternative 2 consists of the following basic elements:

- Designing an engineered cap for the DPF

- Potentially constructing a test cap to evaluate construction and performance parameters (this may be done if the information is required and was included in the cost estimate)

- Disconnecting and removing the pipeline from the decontamination facility to the pond; disposing of this material in an appropriate disposal site 
- Removing the sump located between the pond and the decontamination facility; disposing of this material in an appropriate disposal site

- Pushing the berm material into the pond and sloping to serve as a base for the cap. This material accounts for approximately $60 \%$ of the required fill to bring the pond area to grade prior to capping.

- Importing fill material from a nearby borrow location to bring the pond area to grade. This material will be compacted and sloped to form a stable base for the cap

- Constructing a cap over the DPF and surrounding soils, as needed, using either lowpermeability native playa materials, a mixture of native playa materials with other materials, or some other low-permeability material that will meet closure requirements (for costing purposes, a native playa cap 0.6-m [2-ft] was assumed).

- Armoring the cap (15 cm [6 in.] of Type II material [rip rap] was assumed for the cost estimate)

- Compacting the cap and armoring material using heavy equipment and application of water

- Fencing the cap area to prevent intrusion

- Visually inspecting the site on a routine basis (the exact monitoring activities, period, and schedule will be evaluated in the closure plan; a period of ten years was used for costing)

- Maintaining the cap as required

The post-closure monitoring is assumed to consist of visual inspections on a routine basis with maintenance on an as-needed basis. No groundwater monitoring is proposed because the evaluation of geotechnical and hydrologic properties shows the potential to impact groundwater at this site is nonexistent (DOE/NV, 1997). The modeling (DOE/NV, 1997) shows limited infiltration under the current site conditions. The cap would further retard infiltration. In addition, the cap provides shielding from the radionuclides, further reducing the dose to the future industrial worker. Additional evaluation of monitoring will be conducted in the closure plan.

This alternative meets the closure objective for protectiveness and the closure requirements of the RCRA permit as defined in 40 CFR 265.228 (CFR, 1996e). This alternative poses minimal risk to workers during implementation. 


\subsubsection{Alternative 3 - Clean Closure by Excavation and Disposal}

Alternative 3 consists of removal of all contaminated material above media cleanup levels to obtain clean closure of the DPF. Excavated material would be properly disposed of according to applicable federal and state requirements. No long-term monitoring would be required for this alternative because residual contamination would be below levels of concern. This alternative consists of the following elements:

- Disconnecting and removing the pipeline from the decontamination facility to the pond; disposing of this material in an appropriate location

- Removing the sump located between the pond and the decontamination facility; disposing of this material in an appropriate location

- Excavating all pond and berm material that exceeds the media cleanup levels using heavy equipment

- Disposing of all excavated material as mixed waste to an appropriate on-site or off-site disposal facility. For purposes of costing in this CMS, disposal to NTS Area 5 is assumed. Disposal consists of loading contaminated material at the site to trucks, transportation to the disposal site, waste management sampling by the disposal contractor, and unloading the material. If the Area 5 disposal facility is not a viable option, other on-site or off-site disposal would be required.

- Conducting verification sampling at the DPF to ensure all contaminated materials above cleanup levels have been removed

- Backfilling the excavated area to natural grade with nearby soils. Backfill material will be excavated with scrapers to minimize surface disturbance depth.

This alternative meets the closure objective for protectiveness and the closure requirements of the RCRA permit as defined in 40 CFR 265.228 (CFR, 1996e). However, workers would be exposed to COCs during excavation, transportation, and disposal.

\subsubsection{Alternative 4 - Closure in Place by Partial Excavation and Capping}

Alternative 4 consists of partial excavation of contaminated materials to address the highest levels of COCs and subsequent placement of a cap to prevent infiltration and inadvertent intrusion to the remaining COCs. The highest levels of COCs are located within the top $0.3 \mathrm{~m}(1 \mathrm{ft})$ of the DPF. Removal of this zone would reduce the levels of residual contamination. However, removal of this layer would substantially increase the potential for downward migration of remaining COCs because this layer provides a relatively impermeable boundary for surface water infiltration into 
the subsurface at the DPF. The cap for this alternative would be constructed in the same manner as the cap in Alternative 2. The elements of this alternative include the following:

- Designing an engineered cap for the DPF

- Potentially constructing a test cap to evaluate construction and performance parameters (this may be done if the information is required and was included in the cost estimate)

- Disconnecting, removing, and disposing of the pipeline from the decontamination facility to the pond and disposing to an appropriate facility

- Removing and disposing of the sump located between the pond and the decontamination facility and disposing to an appropriate facility

- Excavating approximately $0.3 \mathrm{~m}(1 \mathrm{ft})$ from the sides of the berms and the pond bottom using heavy equipment

- Disposing of the excavated material in an appropriate solid waste disposal facility (as described in Alternative 3)

- Pushing remaining berm material into the pond and sloping to serve as a base for the cap. This material accounts for approximately $50 \%$ of the required fill to bring the pond area to grade prior to capping.

- Importing fill material from a nearby borrow location to bring the pond area to grade. This material would be compacted and sloped to form a stable base for the cap.

- Constructing a cap over the DPF and surrounding soils, as needed, using either lowpermeability native playa materials, a mixture of native playa materials with other materials, or some other low-permeability material that will meet closure requirements (for costing purposes, a native playa cap 0.6-m [2-ft] was assumed).

- Armoring the cap with a suitable material (approximately $15 \mathrm{~cm}$ [6 in.] rip rap is assumed for the cost estimate)

- Compacting the cap and armoring material using heavy equipment and application of water

- Fencing the cap area to prevent intrusion

- Visually inspecting the site periodically. The monitoring activities, period, and schedule will be evaluated in the closure plan.

- Maintaining the cap as required 
This alternative meets the closure objective for protectiveness and the closure requirements as defined in 40 CFR 265.228 (CFR, 1996e). However, workers would be exposed to COCs during excavation, transportation, and disposal. Removal of the low-permeability layer may result in increased infiltration, especially in the event of a cap failure.

\subsection{Detailed and Comparative Evaluation of Alternatives}

Table 3-5 presents the detailed evaluation of alternatives against the screening criteria. Table 3-6 presents the comparative evaluation of the alternatives against each other using the screening criteria. 
Table 3-5

\section{Detailed Evaluation of Alternatives}

\section{(Page 1 of 3 )}

\begin{tabular}{|c|c|c|c|c|}
\hline Evaluation Criteria & $\begin{array}{c}\text { Alternative } 1 \\
\text { No Action }\end{array}$ & $\begin{array}{l}\text { Alternative } 2 \\
\text { Closure in Place } \\
\text { by Capping }\end{array}$ & $\begin{array}{c}\text { Alternative } 3 \\
\text { Clean Closure } \\
\text { Through Excavation and } \\
\text { Disposal } \\
\end{array}$ & $\begin{array}{c}\text { Alternative } 4 \\
\text { Closure in Place } \\
\text { by Partial Excavation and } \\
\text { Capping } \\
\end{array}$ \\
\hline \multicolumn{5}{|c|}{ Closure Standards } \\
\hline $\begin{array}{l}\text { Protection of Human } \\
\text { Health and the } \\
\text { Environment }\end{array}$ & $\begin{array}{l}\text { - Does not meet closure objectives } \\
\text { or permit requirements } \\
\text { - Does not control spread of COCs } \\
\text { from wind and rain events } \\
\text { - Does not prevent inadvertent } \\
\text { intrusion to contaminated zone } \\
\text { - No worker exposure associated } \\
\text { with implementation } \\
\text { - Does not protect surface water }\end{array}$ & $\begin{array}{l}\text { - Meets closure objectives and } \\
\text { permit closure requirements } \\
\text { - Reduces infiltration } \\
\text { - Significantly reduces exposure } \\
\text { pathways } \\
\text { - Prevents inadvertent intrusion } \\
\text { - Controls run-on/run-off and } \\
\text { protects surface water }\end{array}$ & $\begin{array}{l}\text { - Meets closure objectives and } \\
\text { permit closure requirements } \\
\text { - Minimum residual risk because } \\
\text { all COCs above cleanup } \\
\text { standards are removed } \\
\text { - Protects surface water } \\
\text { - Highest risk to workers during } \\
\text { implementation }\end{array}$ & $\begin{array}{l}\text { - Meets closure objectives and } \\
\text { permit closure requirements } \\
\text { - Significantly reduces exposure } \\
\text { pathways } \\
\text { - Prevents inadvertent intrusion } \\
\text { - Removal of top, low-permeability } \\
\text { layer may increase infiltration and } \\
\text { potential for impacts to surface } \\
\text { water } \\
\text { - Higher risk to workers during } \\
\text { implementation }\end{array}$ \\
\hline $\begin{array}{l}\text { Compliance with Media } \\
\text { Cleanup Standards }\end{array}$ & $\begin{array}{l}\text { Does not comply with media } \\
\text { cleanup standards or standards } \\
\text { for protection of the waters of the } \\
\text { state } \\
\text { - COCs do not pose significant risk } \\
\text { or dose }\end{array}$ & $\begin{array}{l}\text { - Meets standards by significantly } \\
\text { reducing exposure pathways } \\
\text { - Protective of waters of the state } \\
\text { - COCs do not pose significant risk } \\
\text { or dose }\end{array}$ & $\begin{array}{l}\text { - Complies with media cleanup } \\
\text { standards at the DPF } \\
\text { - Protective of waters of the state } \\
\text { - COCs do not pose significant risk } \\
\text { or dose }\end{array}$ & $\begin{array}{l}\text { - Meet standards by significantly } \\
\text { reducing exposure pathways } \\
\text { - May not be protective of waters of } \\
\text { the state because infiltration may } \\
\text { be increased with removal of low- } \\
\text { permeability layer } \\
\text { - COCs do not pose significant risk } \\
\text { or dose }\end{array}$ \\
\hline $\begin{array}{l}\text { Control the Source(s) of } \\
\text { Release }\end{array}$ & $\begin{array}{l}\text { Does not control migration of } \\
\text { COCs through wind or rain } \\
\text { events }\end{array}$ & $\begin{array}{l}\text { - Cap controls migration of COCs } \\
\text { - Dust control during construction } \\
\text { controls spread of COCs } \\
\text { - Cap designed to protect surface } \\
\text { water }\end{array}$ & $\begin{array}{l}\text { - COCs removed } \\
\text { - Dust control during construction } \\
\text { controls spread of COCs } \\
\text { - Transportation accidents could } \\
\text { release COCs }\end{array}$ & $\begin{array}{l}\text { - Removal of low-permeability layer } \\
\text { may increase infiltration } \\
\text { - Cap controls migration of COCs } \\
\text { unless } \\
\text { - Dust control during construction } \\
\text { controls spread of COCs } \\
\text { - Some COCs removed } \\
\text { - Transportation accidents could } \\
\text { release COCs }\end{array}$ \\
\hline $\begin{array}{l}\text { Comply with Applicable } \\
\text { Federal, State, and } \\
\text { Local Standards for } \\
\text { Waste Management }\end{array}$ & - No wastes generated & $\begin{array}{l}\text { - Only limited volume of mixed } \\
\text { waste generated from removal of } \\
\text { piping and sump } \\
\text { - Will be handled and disposed as } \\
\text { mixed waste per applicable } \\
\text { standards }\end{array}$ & $\begin{array}{l}\text { - Large volume of mixed waste } \\
\text { generated } \\
\text { Will be handled and disposed as } \\
\text { mixed waste per applicable } \\
\text { standards }\end{array}$ & $\begin{array}{l}\text { - Significant volume of mixed } \\
\text { waste generated } \\
\text { - Will be handled and disposed as } \\
\text { mixed waste per applicable } \\
\text { standards }\end{array}$ \\
\hline
\end{tabular}


Table 3-5

\section{Detailed Evaluation of Alternatives}

(Page 2 of 3 )

\begin{tabular}{|c|c|c|c|c|}
\hline Evaluation Criteria & $\begin{array}{l}\text { Alternative } 1 \\
\text { No Action }\end{array}$ & $\begin{array}{l}\text { Alternative } 2 \\
\text { Closure in Place } \\
\text { by Capping }\end{array}$ & $\begin{array}{c}\text { Alternative } 3 \\
\text { Clean Closure } \\
\text { Through Excavation and } \\
\text { Disposal } \\
\end{array}$ & $\begin{array}{c}\text { Alternative } 4 \\
\text { Closure in Place } \\
\text { by Partial Excavation and } \\
\text { Capping } \\
\end{array}$ \\
\hline \multicolumn{5}{|c|}{ Remedy Selection Decision Factors } \\
\hline $\begin{array}{l}\text { Short-Term Reliability } \\
\text { and Effectiveness }\end{array}$ & Not evaluated & $\begin{array}{l}\text { - Minimal impacts to workers } \\
\text { during construction } \\
\text { - Public protected by remote } \\
\text { location and access control } \\
\text { - Accident potential associated with } \\
\text { heavy equipment }\end{array}$ & $\begin{array}{l}\text { - Potential for significant worker } \\
\text { exposure during excavation, } \\
\text { transportation, and disposal } \\
\text { - Public exposure and COC } \\
\text { release potential associated with } \\
\text { transportation } \\
\text { - Accident potential associated with } \\
\text { heavy equipment }\end{array}$ & $\begin{array}{l}\text { - Potential for significant worker } \\
\text { exposure during excavation, } \\
\text { transportation, and disposal } \\
\text { - Public exposure and COC } \\
\text { release potential associated with } \\
\text { transportation } \\
\text { - Accident potential associated with } \\
\text { heavy equipment }\end{array}$ \\
\hline $\begin{array}{l}\text { Reduction of Toxicity, } \\
\text { Mobility, and/or Volume }\end{array}$ & Not evaluated & $\begin{array}{l}\text { - Natural radioactive decay } \\
\text { reduces toxicity, mobility, and } \\
\text { volume of radionuclides } \\
\text { - Cap reduces mobility to } \\
\text { groundwater and surface water }\end{array}$ & $\begin{array}{l}\text { - Natural radioactive decay } \\
\text { reduces toxicity, mobility, and } \\
\text { volume of radionuclides } \\
\text { - All three reduced at DPF, but } \\
\text { same volume and toxicity in } \\
\text { disposal location }\end{array}$ & $\begin{array}{l}\text { - Natural radioactive decay } \\
\text { reduces toxicity, mobility, and } \\
\text { volume of radionuclides } \\
\text { - All three reduced at DPF, but } \\
\text { same volume and toxicity in } \\
\text { disposal location } \\
\text { - Removal of low-permeability layer } \\
\text { may increase infiltration and } \\
\text { mobility of COCs }\end{array}$ \\
\hline $\begin{array}{l}\text { Long-Term Reliability } \\
\text { and Effectiveness }\end{array}$ & Not evaluated & $\begin{array}{l}\text { - Small residual risk } \\
\text { - Cap limits infiltration and protects } \\
\text { waters of the state } \\
\text { - Controls inadvertent intrusion } \\
\text { - Monitoring and maintenance of } \\
\text { cap required } \\
\text { - Limited impacts from failure of } \\
\text { cap because low-permeability } \\
\text { layer protects groundwater and } \\
\text { surface water }\end{array}$ & $\begin{array}{l}\text { - Small residual risk } \\
\text { - No monitoring required } \\
\text { - No impacts from failure }\end{array}$ & $\begin{array}{l}\text { - Small residual risk } \\
\text { - Removal of low-permeability layer } \\
\text { may result in increased infiltration } \\
\text { - Monitoring and maintenance of } \\
\text { cap required }\end{array}$ \\
\hline
\end{tabular}




\section{Table 3-5}

\section{Detailed Evaluation of Alternatives}

(Page 3 of 3 )

\begin{tabular}{|c|c|c|c|c|}
\hline Evaluation Criteria & $\begin{array}{l}\text { Alternative } 1 \\
\text { No Action }\end{array}$ & $\begin{array}{c}\text { Alternative } 2 \\
\text { Closure in Place } \\
\text { by Capping }\end{array}$ & $\begin{array}{c}\text { Alternative } 3 \\
\text { Clean Closure } \\
\text { Through Excavation and } \\
\text { Disposal }\end{array}$ & $\begin{array}{c}\text { Alternative } 4 \\
\text { Closure in Place } \\
\text { by Partial Excavation and } \\
\text { Capping }\end{array}$ \\
\hline Feasibility & Not evaluated & $\begin{array}{l}\text { - Easily implementable } \\
\text { - Must identify suitable capping } \\
\text { materials }\end{array}$ & $\begin{array}{l}\text { - Feasibility dependant on disposal } \\
\text { availability and capacity } \\
\text { - Off-site transportation and } \\
\text { disposal, if required, may not be } \\
\text { publicly or regulatorily accepted } \\
\text { - Disposal as mixed waste required }\end{array}$ & $\begin{array}{l}\text { - Feasibility dependant on disposal } \\
\text { availability and capacity } \\
\text { - Must identify suitable capping } \\
\text { materials } \\
\text { - Off-site transportation and } \\
\text { disposal, if required, may not be } \\
\text { publicly or regulatorily accepted } \\
\text { - Disposal as mixed waste required }\end{array}$ \\
\hline Cost & $\$ 150,000$ & $\$ 1,000,000$ & $\$ 16,000,000$ & $\$ 3,000,000$ \\
\hline
\end{tabular}




\section{Table 3-6}

\section{Comparative Evaluation of Alternatives}

\section{(Page 1 of 2)}

\begin{tabular}{|c|c|}
\hline Evaluation Criteria & Comparative Evaluation \\
\hline \multicolumn{2}{|r|}{ Closure Standards } \\
\hline $\begin{array}{l}\text { Protection of Human Health } \\
\text { and the Environment }\end{array}$ & $\begin{array}{l}\text { Alternatives 2, 3, and } 4 \text { meet closure objectives and permit requirements; Alternative } 1 \text { does not. Alternatives } 2 \text { and } 3 \text { are } \\
\text { protective of the waters of the state; Alternative } 4 \text { may impact waters of the state because the removal of the low- } \\
\text { permeability layer may result in increased infiltration. Alternative } 1 \text { does not protect waters of the state from COCs. } \\
\text { Current risk and dose levels are low for all alternatives. }\end{array}$ \\
\hline $\begin{array}{l}\text { Compliance with Media } \\
\text { Cleanup Standards }\end{array}$ & $\begin{array}{l}\text { Alternative } 3 \text { complies with media cleanup levels and is protective of the surface water. Alternatives } 2 \text { and } 4 \text { meet media } \\
\text { cleanup standards by substantially reducing exposure pathways. Alternative } 2 \text { is protective of the surface water; } \\
\text { Alternative } 4 \text { may not adequately protect the surface water because infiltration may be increased with removal of the low- } \\
\text { permeability layer. }\end{array}$ \\
\hline $\begin{array}{l}\text { Control the Source(s) of the } \\
\text { Release }\end{array}$ & $\begin{array}{l}\text { Alternative } 2 \text { controls the sources of release by installation of the cap and because waste transportation is not required. } \\
\text { Alternatives } 3 \text { controls the sources of release after implementation but has the potential for release associated with } \\
\text { excavation and transportation of contaminated materials. Alternative } 4 \text { has potential for release during excavation and } \\
\text { transportation and through increased infiltration associated with removal of the low-permeability layer. Alternative } 1 \text { does } \\
\text { not control the sources of release associated with meteorologic events. }\end{array}$ \\
\hline $\begin{array}{l}\text { Comply with Applicable } \\
\text { Federal, State, and Local } \\
\text { Standards for Waste } \\
\text { Management }\end{array}$ & $\begin{array}{l}\text { Alternative } 1 \text { does not generate any waste. Alternative } 2 \text { generates only minimal mixed waste from removal of the piping } \\
\text { and sump. Alternatives } 3 \text { and } 4 \text { both generate significant amounts of mixed waste. All waste will be managed and } \\
\text { disposed per applicable standards. }\end{array}$ \\
\hline \multicolumn{2}{|r|}{ Remedy Selection Decision Factors } \\
\hline $\begin{array}{l}\text { Short-Term Reliability and } \\
\text { Effectiveness }\end{array}$ & $\begin{array}{l}\text { Alternative } 2 \text { results in minimal exposure to workers and the public during implementation. Alternatives } 3 \text { and } 4 \text { have a } \\
\text { higher degree of worker exposure and the potential for public exposure associated with waste transportation. Accident } \\
\text { potential associated with heavy equipment usage exists for Alternatives } 2,3 \text {, and } 4 \text {. }\end{array}$ \\
\hline $\begin{array}{l}\text { Reduction of Toxicity, Mobility, } \\
\text { and/or Volume }\end{array}$ & $\begin{array}{l}\text { Alternative } 3 \text { results in the greatest reduction of toxicity, mobility, and volume at the DPF because COCs above media } \\
\text { cleanup standards are removed. Alternative } 2 \text { reduces mobility by the installation of a cap. Alternative } 4 \text { results in a } \\
\text { reduction of all three parameters by removal and capping; however, because the low-permeability layer is removed, } \\
\text { mobility of the remaining COCs may be increased. All alternatives have reduced toxicity, mobility, and volume of } \\
\text { radionuclides associated with natural radioactive decay. }\end{array}$ \\
\hline
\end{tabular}




\section{Table 3-6}

\section{Comparative Evaluation of Alternatives}

\section{(Page 2 of 2 )}

\begin{tabular}{||l|l||}
\hline \multicolumn{1}{|c|}{ Evaluation Criteria } & \multicolumn{1}{c|}{ Comparative Evaluation } \\
\hline \hline Long-Term Reliability and \\
Effectiveness & $\begin{array}{l}\text { Residual risk for all alternatives is low. Alternative } 3 \text { has the highest degree of long-term reliability because COCs are } \\
\text { removed and no long-term monitoring is required. Alternative } 2 \text { provides the next highest long-term reliability because the } \\
\text { cap controls exposure, limits infiltration, and protects surface water. Alternative } 4 \text { is likely protective, but the removal of the } \\
\text { low-permeability layer may result in increased infiltration and potential migration of COCs. Alternatives } 2 \text { and } 3 \text { require } \\
\text { long-term monitoring and maintenance. }\end{array}$ \\
\hline Feasibility & $\begin{array}{l}\text { Alternative } 2 \text { is feasible and easily implementable; a suitable capping material must be identified prior to construction. } \\
\text { Alternatives } 3 \text { and } 4 \text { require disposal capacity and availability for significant volumes of mixed waste. Alternatives } 3 \text { and } 4 \\
\text { require potential shipment of waste off-site, which may meet public resistance. }\end{array}$ \\
\hline Cost & $\begin{array}{l}\text { The cost for Alternative } 1 \text { is } \$ 150,000 \text { for monitoring COC migration associated with meteorologic events. The cost for } \\
\text { Alternative } 2 \text { is } \$ 1,000,000 \text { for installation of a cap. Uncertainties include the type of capping material and the construction } \\
\text { of a test cap section. The cost for Alternative } 4 \text { is } \$ 3,000,000 \text { for partial removal and disposal of contaminated material and } \\
\text { construction of a cap. Uncertainties include the type of capping material, construction of a test cap section, and disposal } \\
\text { capacity and cost. The cost for Alternative } 3 \text { is } \$ 16,000,000 \text { for removal and disposal of contaminated material with } \\
\text { concentrations above media cleanup standards. Uncertainties include disposal capacity and cost. }\end{array}$ \\
\hline \hline
\end{tabular}




\subsection{Recommended Alternative}

Based on the detailed and comparative analyses presented in Section 3.0, the preferred closure alternative for CAU No. 92, the DPF, is Alternative 2 - Closure in Place by Capping. This alternative was selected as the most cost-effective method of meeting closure objectives and complying with regulatory requirements. The following provides justification for the selection of this alternative:

- The alternative meets the requirements of the RCRA permit for closure of a surface impoundment.

- The alternative is protective of human health and the environment by limiting infiltration and inadvertent intrusion through installation of a cap. The cap will be designed to direct water away from the contaminated zone and to withstand severe meteorologic events through armoring. The impermeable layer in the top $0.3-\mathrm{m}(1-\mathrm{ft})$ of the DPF provides a barrier to infiltration in the event of a cap failure. The cap will also limit exposure to radionuclides. All waste is managed according to applicable standards and disposed as appropriate.

- $\quad$ The alternative achieves media cleanup standards.

- The alternative controls the source of any potential release through proper cap design and construction. The cap addresses the release of airborne COC and direct exposure to radiation while providing protection for surface and groundwater.

- The alternative minimizes exposures to workers. Short-term impacts associated with the alternative are controllable through implementation of health and safety procedures. Short-term impacts to the community are not a concern because the site is accesscontrolled, remotely located, and no off-site transportation of contaminated materials is required.

- $\quad$ After implementation, the risks and doses associated with the site are reduced below the currently acceptable risk and dose levels as discussed in Appendices A and B.

The preferred closure alternative was evaluated on its technical merits with focus on performance, reliability, feasibility, and safety. The alternative was judged to meet all requirements of the technical components evaluated and is the most cost-effective closure option. 
During implementation, this alternative will present a minimal potential threat to site workers and the environment. As a future work precaution, appropriate safety procedures will be addressed in the Closure Plan. After completion of the recommended closure alternative, the CAU will not pose a threat to human health or the environment because potential exposure pathways are removed. 


\subsection{References}

CFR, see Code of Federal Regulations.

Code of Federal Regulations. 1996a. 40 CFR 261.24, "Toxicity Characteristic."

Washington, DC: U.S. Government Printing Office.

Code of Federal Regulations. 1996b. 40 CFR 261.31, "Hazardous Wastes from Non-specific Sources." Washington, DC: U.S. Government Printing Office.

Code of Federal Regulations. 1996c. 40 CFR 265, "Interim Status Standards for Owners and Operators of Hazardous Waste Treatment, Storage, and Disposal Facilities." Washington, DC: U.S. Government Printing Office.

Code of Federal Regulations. 1996d. 40 CFR 265 Subpart G, "Closure and Post-Closure." Washington, DC: U.S. Government Printing Office.

Code of Federal Regulations. 1996e. 40 CFR 265.228, "Closure and Post-Closure Care."

Washington, DC: U.S. Government Printing Office.

Code of Federal Regulations. 1996f. 40 CFR 265.310, "Closure and Post-Closure Care."

Washington, DC: U.S. Government Printing Office.

Code of Federal Regulations. 1996g. 40 CFR 268, "Land Disposal Restrictions."

Washington, DC: U.S. Government Printing Office.

Code of Federal Regulations. 1996h. 40 CFR Parts 261-281, RCRA Regulations.

Washington, DC: U.S. Government Printing Office.

DOE, see U.S. Department of Energy.

DOE/NV, see U.S. Department of Energy, Nevada Operations Office.

EPA, see U.S. Environmental Protection Agency.

FFACO, see Federal Facility Agreement and Consent Order.

Federal Facility Agreement and Consent Order. 1996. Agreed to by the State of Nevada, the U.S. Department of Energy, and the U.S. Department of Defense.

NAC, see Nevada Administrative Code.

Nevada Revised Statutes. 1995a. NRS 445.415 "Waters of the State." Carson City, NV. 
Nevada Revised Statute. 1995b. NRS 459.400 - 459.600, "Disposal of Hazardous Waste." Carson City, NV.

Nevada Administrative Code. 1990a. NAC 459.9973, "Action by Division When Excessive Petroleum Is Present in Soil." Carson City, NV.

Nevada Administrative Code. 1990b. NAC 459.9974, "Disposal and Evaluation of Contaminated Soil." Carson City, NV.

Nevada Administrative Code. 1995. NAC 445A.119 - 445A.213, "Standards for Water Quality." Carson City, NV.

NDEP, see Nevada Division of Environmental Protection.

NRS, see Nevada Revised Statute.

Nevada Division of Environmental Protection. 1995. Nevada Division of Environmental Protection Permit for a Hazardous Waste Management Facility, Nevada Test Site, NEV HW009. Carson City, NV.

U.S. Department of Energy. 1993. Radiation Protection of the Public and the Environment, DOE Order 5400.5. Washington, DC: U.S. Government Printing Office.

U.S. Department of Energy, Nevada Operations Office. 1994. Project Management Plan. Las Vegas, NV.

U.S. Department of Energy, Nevada Operations Office. 1996a. Final Environmental Impact Statement for the Nevada Test Site and Off-Site Locations in the State of Nevada, DOE/EIS 0243. Las Vegas, NV.

U.S. Department of Energy, Nevada Operations Office. 1996b. Industrial Sites Quality Assurance Project Plan, DOE/NV-438. Las Vegas, NV.

U.S. Department of Energy, Nevada Operations Office. 1996c. Nevada Test Site Waste Acceptance Criteria, NTSWAC, Rev. 0. Las Vegas, NV.

U.S. Department of Energy. Nevada Operations Office. 1996d. Record of Decision: Environmental Impact Statement for the Nevada Test Site and Off-Site Locations in the State of Nevada, 6450-01-P. Las Vegas, NV.

U.S. Department of Energy, Nevada Operations Office. 1996e. Resource Conservation and Recovery Act Industrial Site Environmental Restoration Characterization Plan, Area 6 Decontamination Pond Facility, DOE/NV-372, Rev. 1. Las Vegas, NV. 
U.S. Department of Energy, Nevada Operations Office. 1997. Resource Conservation and Recovery Act Industrial Site Environmental Restoration Characterization Report, Area 6 Decontamination Pond Facility, DOE/NV-470, Rev. 1. Las Vegas, NV.

U.S. Environmental Protection Agency. 1991. Guidance on Resource Conservation and Recovery Act Corrective Action Decision Documents, EPA/540/G-91/011. Washington, DC: U.S. Government Printing Office.

U.S. Environmental Protection Agency. 1994. Final Resource Conservation and Recovery Act Corrective Action Plan, EPA 520-R-94-004. Washington, DC: U.S. Government Printing Office.

U.S. Environmental Protection Agency. 1996a. Region IX Preliminary Remediation Goals. San Francisco, CA.

U.S. Environmental Protection Agency. 1996b. Soil Screening Guidance: User's Guide, 9355.4-23. Washington, DC: Office of Solid Waste and Emergency Response. 
RCRA DPF CAU 92

Appendix A

Revision: 0

Date: $10 / 31 / 97$

Page A-i of A-v

\section{Appendix A}

\section{Chemical Risk Assessment Area 6 Decontamination Pond Facility}




\section{Table of Contents}

List of Tables $\ldots \ldots \ldots \ldots \ldots \ldots \ldots \ldots \ldots \ldots \ldots \ldots \ldots \ldots \ldots \ldots \ldots$

List of Acronyms and Abbreviations $\ldots \ldots \ldots \ldots \ldots \ldots \ldots \ldots \ldots \ldots \ldots \ldots \ldots$

A.1.0 Introduction $\ldots \ldots \ldots \ldots \ldots \ldots \ldots \ldots \ldots \ldots \ldots \ldots \ldots \ldots \ldots$

A.2.0 Conceptual Site Model $\ldots \ldots \ldots \ldots \ldots \ldots \ldots \ldots \ldots \ldots \ldots \ldots \ldots \ldots$ A $2 \ldots \ldots$

A.3.0 Determination of Chemicals of Concern $\ldots \ldots \ldots \ldots \ldots \ldots \ldots \ldots \ldots$

A.4.0 Exposure Point Concentrations . . . . . . . . . . . . . . . A-5

A.4.1 Calculation of Concentration Term for Soils $\ldots \ldots \ldots \ldots \ldots \ldots \ldots \ldots$ A $\ldots \ldots$

A.4.2 Presentation of Data . . . . . . . . . . . . . . . . . .

A.5.0 Quantification of Intake $\ldots \ldots \ldots \ldots \ldots \ldots \ldots \ldots \ldots \ldots \ldots \ldots \ldots \ldots$

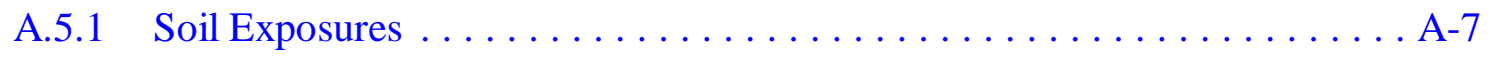

A.5.2 Incidental Ingestion $\ldots \ldots \ldots \ldots \ldots \ldots \ldots \ldots \ldots \ldots \ldots \ldots \ldots$

A.5.3 Dermal Contact .......................... A-9

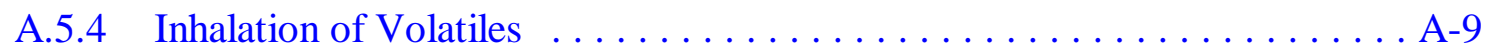

A.5.5 Inhalation of Particulates $\ldots \ldots \ldots \ldots \ldots \ldots \ldots \ldots \ldots \ldots \ldots$

A.6.0 Toxicity Assessment $\ldots \ldots \ldots \ldots \ldots \ldots \ldots \ldots \ldots \ldots \ldots \ldots$. . . . . . . . . .

A.6.1 Toxicity Assessment for Carcinogenic and Noncarcinogenic Effects .... . A-11

A.6.2 Chemical-Specific Issues . . . . . . . . . . . . . . . . A-11

A.6.2.1 Lead ......................... A-11

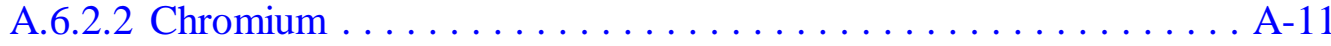

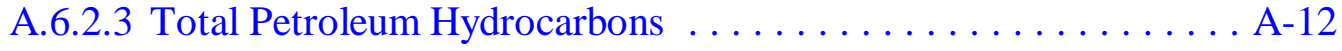

A.7.0 Risk Characterization $\ldots \ldots \ldots \ldots \ldots \ldots \ldots \ldots \ldots \ldots \ldots \ldots \ldots \ldots$

A.7.1 Calculation of Carcinogenic Risk . . . . . . . . . . . . . A-14

A.7.2 Calculation of Noncancer Hazard . . . . . . . . . . . . . . A-14 


\section{Table of Contents (Continued)}

A.7.3 Human Health Risk Assessment Results . . . . . . . . . . . . . . . . . A-15

A.7.3.1 Carcinogenic Results . . . . . . . . . . . . . . . . A-16

A.7.3.2 Noncarcinogenic Results . . . . . . . . . . . . . . . A-16

A.7.4 Conclusion ......................... A-21

A.8.0 Uncertainty Assessment $\ldots \ldots \ldots \ldots \ldots \ldots \ldots \ldots \ldots \ldots \ldots \ldots$ A 22

A.8.1 Methodological Uncertainty . . . . . . . . . . . . . . . A-22

A.8.1.1 Contaminant Concentration . . . . . . . . . . . A - 22

A.8.1.2 Exposure Assessment . . . . . . . . . . . . . A-22

A.8.1.3 Toxicity Assessment . . . . . . . . . . . . . A-23

A.8.1.4 Risk Characterization $\ldots \ldots \ldots \ldots \ldots \ldots \ldots \ldots \ldots \ldots \ldots \ldots$

A.8.2 Site-Specific Uncertainties . . . . . . . . . . . . . . A-23

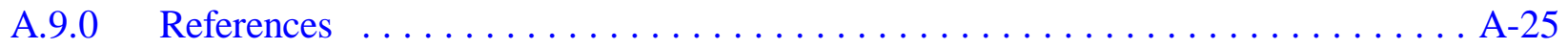

Attachment A.1 - Risk Calculation Tables $\ldots \ldots \ldots \ldots \ldots \ldots \ldots \ldots \ldots \ldots$. . . . . . . . . 


\section{List of Tables}

Number

Title

Page

A.2-1 Conceptual Site Model for Exposure to Chemical COCs $\ldots \ldots \ldots \ldots \ldots \ldots$. . . A-3

A.5-1 Parameters Used to Estimate Potential Exposures $\ldots \ldots \ldots \ldots \ldots \ldots$. . . . A

A.6-1 Toxicity Data for Contaminants of Concern $\ldots \ldots \ldots \ldots \ldots \ldots \ldots \ldots$. . . . . . . . .

A.7-1 Selection of Contaminants of Concern at the DPF, Surface Soil . . . . . . . . A-17

A.7-2 Selection of Contaminants of Concern at the DPF, Subsurface Soil . . . . . . . . A-19

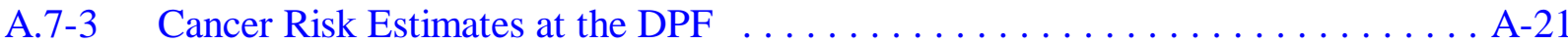

A.7-4 Noncancer Risk Estimate for the DPF . . . . . . . . . . . . . . . . . . . A-21

Attachment A.1 - Risk Calculation Tables

1 Radiological Worker Cancer Risk from Exposure to COCs in Area 6 DPF . . . A A-28

2 Radiological Worker Noncancer Risk from Exposure to COCs in Area 6 DPF . . A-29

3 Industrial Worker Cancer Risk from Exposure to COCs in Area 6 DPF . . . . . A-30

4 Industrial Worker Noncancer Risk from Exposure to COCs in Area DPF . . . . . A-31 


\section{List of Acronyms and Abbreviations}

$\begin{array}{ll}\text { bgs } & \text { Below ground surface } \\ \mathrm{COC} & \text { Contaminant of concern(s) } \\ \mathrm{cm} & \text { Centimeter(s) } \\ \mathrm{cm}^{2} & \text { Square centimeter(s) } \\ \mathrm{DPF} & \text { Decontamination Pond Facility } \\ \mathrm{EPA} & \text { U.S. Environmental Protection Agency } \\ \mathrm{ft} & \text { Foot (feet) } \\ \mathrm{g} & \text { Gram(s) } \\ \mathrm{HEAST} & \text { Health Effects Assessment Summary Tables } \\ \mathrm{HI} & \text { Hazard index } \\ \mathrm{HQ} & \text { Hazard quotient } \\ \mathrm{IRIS} & \text { Integrated Risk Information System } \\ \mathrm{kg} & \text { Kilogram(s) } \\ \mathrm{m} & \text { Meter(s) } \\ \mathrm{MDEP} & \text { Massachusetts Department of Environmental Protection } \\ \mathrm{mg} / \mathrm{kg} & \text { Milligram(s) per kilogram } \\ \text { NTS } & \text { Nevada Test Site } \\ \text { PRG } & \text { Preliminary remediation goal(s) } \\ \text { RfD } & \text { Reference dose(s) } \\ \text { RME } & \text { Reasonable maximum exposure } \\ \mathrm{SFs} & \text { Slope factor(s) } \\ \mathrm{SQL} & \text { Sample quantitation limit } \\ \text { TPH } & \text { Total petroleum hydrocarbon } \\ \mathrm{UCL} & \text { Upper confidence limit } \\ \mu \mathrm{g} / \mathrm{dL} & \text { Microgram(s) per decaliter } \\ & \end{array}$




\section{A.1.0 Introduction}

This appendix contains the human health risk assessment based on chemical contamination at the Nevada Test Site (NTS) Area 6 Decontamination Pond Facility (DPF). The methodologies and results of this assessment are provided in the following sections.

The human health risk assessment has been prepared for the DPF to support evaluation of closure options at the site. The objectives of the risk assessment are to:

- Provide an analysis of baseline risks;

- Provide a basis for determining levels of chemicals that can remain on-site at levels protective of public health;

- Provide a basis for comparing potential health impacts of closure alternatives.

The risk assessment considered only chemical contaminants of concern (COCs). Radiological COCs are evaluated in the dose assessment as shown in Appendix B of the Corrective Measures Study. 


\section{A.2.0 Conceptual Site Model}

The conceptual site model provides the basis for identifying and evaluating the potential risks to human health through the baseline risk assessment. The conceptual model facilitates consistent and comprehensive evaluation of risks by creating a framework for identifying the paths by which humans may be impacted by the DPF.

The elements necessary to construct a complete exposure pathway and develop the conceptual model include:

- Sources and potential COCs

- Release mechanisms

- Transport pathways

- Exposure pathway scenarios

- Receptors

Table A.2-1 presents the conceptual site model for potential human and environmental exposures to the soils of the DPF and defines the evaluated pathways. The receptor exposure scenarios included in the DPF conceptual model include:

- Radiological Worker - This exposure scenario is based on the assumption that a radiological worker conducts activities in the DPF study area that result in exposure to COCs in the surface soils. The worker conducts surveillance of the DPF following eight meteorologic events a year. Exposure routes for this receptor include:

- Incidental ingestion of soil

- Inhalation of fugitive dusts and volatile organics in the soil

- Dermal contact with chemicals in the soil

- Industrial Worker - This exposure scenario is based on the assumption that an industrial worker is working in an office-type setting at the DPF. Industrial worker exposures to subsurface soil include more traditional 8 hour, 250 day/year exposures. Exposure routes for this receptor include:

- Incidental ingestion of soil

- Inhalation of fugitive dusts and volatile organics in the soil

- Dermal contact with chemicals in the soil

Details concerning the assumptions and parameters used to estimate the reasonable maximum exposure (RME) are provided in Section A.5.0. 
Table A.2-1

Conceptual Site Model for Exposure to Chemical COCs

\begin{tabular}{|c|c|c|c|}
\hline $\begin{array}{c}\text { Potentially Exposed } \\
\text { Population }\end{array}$ & $\begin{array}{c}\text { Exposure Route and } \\
\text { Medium }\end{array}$ & $\begin{array}{c}\text { Pathway Selected for } \\
\text { Evaluation }\end{array}$ & $\begin{array}{c}\text { Reason for Selection } \\
\text { or Exclusion }\end{array}$ \\
\hline \multicolumn{4}{|l|}{ Current Land Use } \\
\hline Radiological worker & Dermal contact & No & $\begin{array}{l}\text { Workers required to } \\
\text { wear personal } \\
\text { protective equipment }\end{array}$ \\
\hline Radiological worker & Inhalation of dust & No & $\begin{array}{l}\text { Workers required to } \\
\text { wear respirators }\end{array}$ \\
\hline Radiological worker & $\begin{array}{l}\text { Inadvertent soil } \\
\text { ingestion }\end{array}$ & No & $\begin{array}{l}\text { Workers required to } \\
\text { wear personnel } \\
\text { protective equipment }\end{array}$ \\
\hline$\frac{\text { Future Land Use }}{\text { Radiological worker }}$ & $\begin{array}{l}\text { Dermal contact with } \\
\text { chemicals, inhalation } \\
\text { of fugitive dust, } \\
\text { incidental soil ingestion }\end{array}$ & Yes & $\begin{array}{l}\text { No controls are } \\
\text { assumed }\end{array}$ \\
\hline Industrial worker & $\begin{array}{l}\text { Dermal contact with } \\
\text { chemicals, inhalation } \\
\text { of fugitive dust, } \\
\text { incidental soil ingestion }\end{array}$ & Yes & No controls assumed. \\
\hline Resident & $\begin{array}{l}\text { Ingestion of } \\
\text { groundwater from local } \\
\text { wells, dermal contact } \\
\text { with chemicals, } \\
\text { inhalation of fugitive } \\
\text { dust, incidental soil } \\
\text { ingestion }\end{array}$ & No & $\begin{array}{l}\text { Residents at the DPF } \\
\text { are assumed to be } \\
\text { highly unlikely }\end{array}$ \\
\hline
\end{tabular}




\section{A.3.0 Determination of Chemicals of Concern}

The selection of chemical COCs is based on a risk-based concentration screen developed by U.S. Environmental Protection Agency (EPA) Region III (EPA, 1993). The purpose of this screen is to make the baseline risk-assessment process more efficient by focusing on the dominant chemicals and routes of exposure at the earliest feasible stage.

The risk-based concentration screen is used as follows:

- The maximum concentration is identified for each chemical detected in each medium.

- The maximum concentration is compared to the risk-based concentration for that medium. The risk-based concentrations are EPA Region IX Preliminary Remediation Goals (PRGs) (EPA, 1996) which have been multiplied by a safety factor of 0.1. Region IX PRGs were used because they account for oral, inhalation, and dermal exposures.

- If a specific chemical exceeds the risk-based concentration, the chemical is retained for the risk assessment for all routes of exposure involving that medium.

In addition to the risk-based concentration screen, detection frequency is applied in the selection of COCs. Chemicals that are detected infrequently (i.e., in less than 5 percent of the samples) are eliminated from the $\mathrm{COC}$ list. Exceptions are made for Class A carcinogens, which remain on the COC list regardless of their detection frequency. 


\section{A.4.0 Exposure Point Concentrations}

The exposure point concentration is the concentration of a COC in an exposure medium that will be contacted by an actual or hypothetical receptor. Determination of the exposure point concentration depends on factors such as:

- Availability of data

- Amount of data available to perform statistical analysis

- Background concentrations (not attributable to site contamination)

- Location of the potential receptor

In most cases, analytes are below the applicable detection limit in each sample. Nondetected results are reported as less than the sample quantitation limit (SQL). The chemical may be present at the concentration just below the reported quantitation limit, or it may not be present in the sample at all. Therefore, as a standard conservative approach to determine the concentrations most representative of potential exposures to chemicals detected at least once, nondetected results will be treated as one-half the SQL as a proxy concentration for purposes of statistical calculations.

Duplicate pairs of data will be summarized as one sample by including the higher concentration of any analyte.

Background concentrations of contaminants are not subtracted from media concentrations when determining exposure-point concentrations for chemicals. Chemical toxicants pose risks at threshold levels; therefore, total intakes must be compared to the intake level associated with toxic levels. Background concentrations were not available for comparison with measured values.

\section{A.4.1 Calculation of Concentration Term for Soils}

The concentration term in the intake equation is an estimate of the arithmetically-averaged concentration for a contaminant based on a set of site sampling results (EPA 1989 and 1992). Because of the uncertainty associated with estimating the true average concentration at a site, the 95 percent upper confidence limit (UCL) of the arithmetic mean is used for this variable. The UCL provides reasonable confidence that the true site average will not be underestimated. 
The EPA has determined that most large environmental contaminant datasets from soil sampling activities are lognormally distributed rather than normally distributed (EPA, 1992). The W-test (Gilbert, 1987) is used to determine the appropriate distribution describing each dataset obtained during the characterization activities. If a dataset cannot be described by either the lognormal or normal distribution, the lognormal distribution is chosen as the default. No datasets were found to be normally distributed. The equation used to calculate the UCL for the lognormal distribution is shown below:

$$
\mathrm{UCL}=\mathrm{e}^{\overline{\mathrm{x}}+0.5 \mathrm{~s}^{2}+\mathrm{sH} / \sqrt{\mathrm{n}-1}}
$$

where:

$$
\begin{array}{ll}
\mathrm{UCL} & =95 \% \text { upper confidence limit; } \\
\mathrm{e} & =\text { constant (base of the natural log, equal to } 2.718) \\
\bar{x} & =\text { arithmetic mean of transformed data; } \\
\mathrm{S} & =\text { standard deviation of the transformed data; } \\
\mathrm{H} & =\text { H-statistic (Gilbert, 1987); and } \\
\mathrm{n} & =\text { number of samples. }
\end{array}
$$

For sample sets with more than five samples, the UCL is calculated and chosen as the representative concentration of that COC. If the calculated UCL is greater than the maximum detected value for that constituent, the representative concentration of that COC will be selected as the maximum detected value rather than the UCL. For sample sets with fewer than five samples, the representative concentration will be the maximum detected value.

\section{A.4.2 Presentation of Data}

Data for each area of concern are presented in tabular format with headings for chemical contaminant, frequency of detection, maximum detected value, statistical distribution, 95 percent UCL, screening criterion, and representative concentration (if chosen as a COC). 


\section{A.5.0 Quantification of Intake}

This section describes the method used to quantify chronic exposures for exposure pathways identified in the conceptual model for DPF. Exposures are determined to characterize the RME. The RME is the maximum exposure reasonably expected to occur at the site (EPA, 1989). If the RME is determined to be acceptable, then it is likely that all other lesser exposures at the site will also be acceptable. Exposure parameters used to estimate the RME are provided in Table A.5-1 for soil exposure pathways.

\section{A.5.1 Soil Exposures}

Soil exposures are evaluated for radiological and industrial worker exposure scenarios as described in Section 2.2.

\section{A.5.2 Incidental Ingestion}

The estimation of intake of COCs in soil is determined using the concentration in the soil at the location of interest (EPA, 1989).

$$
\mathrm{I}_{\mathrm{s}}=\frac{\mathrm{C}_{\mathrm{s}} \cdot \mathrm{IR} \cdot \mathrm{CF} \cdot \mathrm{FI} \cdot \mathrm{EF} \cdot \mathrm{ED}}{\mathrm{BW} \cdot \mathrm{AT}}
$$

where:

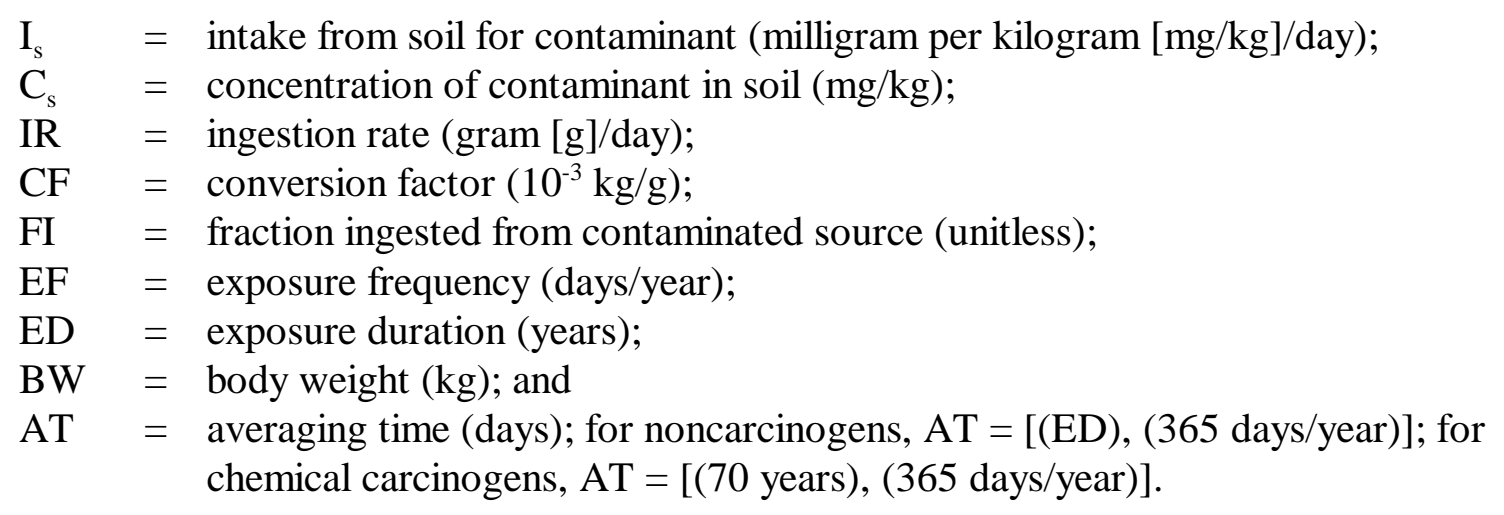


Table A.5-1

Parameters Used to Estimate Potential Exposures ${ }^{a, b}$

\begin{tabular}{|c|c|c|}
\hline Pathway Parameter & $\begin{array}{l}\text { Radiological } \\
\text { Worker }\end{array}$ & $\begin{array}{l}\text { Industrial } \\
\text { Worker }\end{array}$ \\
\hline \multicolumn{3}{|c|}{ Parameters Common to All Pathways } \\
\hline Averaging Time - Noncancer (days) & $10,950^{c}$ & $10,950^{c}$ \\
\hline Averaging Time - Cancer (days) & $25,550^{d}$ & $25,550^{d}$ \\
\hline Exposure Duration (years) & $30^{e}$ & $30^{e}$ \\
\hline Body Weight (kg) & 70 & 70 \\
\hline \multicolumn{3}{|c|}{ Incidental Ingestion of Soil } \\
\hline Ingestion Rate (mg/day) & 50 & 50 \\
\hline Fraction Ingested (unitless) & 1 & 1 \\
\hline Exposure Frequency (days/year) & 8 & 250 \\
\hline \multicolumn{3}{|c|}{ Inhalation of Volatiles and Particulates from Soil } \\
\hline Inhalation Rate ( $\mathrm{m}^{3} /$ day) & 37 & 20 \\
\hline Exposure Frequency (days/year) & 8 & 250 \\
\hline \multicolumn{3}{|c|}{ Dermal Exposure To Soil } \\
\hline Skin Surface Area $\left(\mathrm{cm}^{2}\right)$ & $5000^{f}$ & $5000^{f}$ \\
\hline Skin Adherence Factor $\left(\mathrm{mg} / \mathrm{cm}^{2}\right)$ & $1.0^{\mathrm{g}}$ & $0.2^{\mathrm{g}}$ \\
\hline Absorption Factor (unitless) & Chemical-specific & Chemical-specific \\
\hline Exposure Frequency (days/year) & 8 & 250 \\
\hline
\end{tabular}

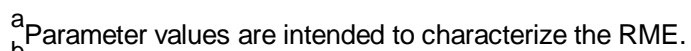

${ }^{b}$ Parameter values obtained from Risk Assessment Guidance for Superfund, Volume 1: Human Health Evaluation Manual,

Supplemental Guidance: "Standard Default Exposure Factors." OSWER Directive 9285.6-03, March 25, 1991, unless otherwise noted.

${ }_{d}^{c}$ Calculated as the product of exposure duration (years) $\times 365$ days/year.

${ }^{d}$ Calculated as the product of 70 years (assumed lifetime) $\times 365$ days/year.

Best professional judgment.

Fraction Ingested: For RME, it is assumed that 100 percent of the soil ingested on days that the site is visited is attributable to the site.

- $\quad$ Exposure Duration: The radiological worker scenario assumes an 8 day per year exposure frequency for 30 years. The industrial worker scenario is based on 30 years of employment at DPF and performance of the same job.

fDermal Exposure Assessment, EPA/600/8-91/011B (EPA, 1991a).

${ }^{9}$ Exposure Factors Handbook, EPA/600/P-95/002A (EPA, 1995a). 


\section{A.5.3 Dermal Contact}

The estimation of intake of organic COCs in soil via absorption through the skin is determined using the concentration in the soil at the location evaluated (EPA, 1991b) as follows:

$$
\mathrm{AB}_{\mathrm{s}}=\frac{\mathrm{C} \cdot \mathrm{CF} \cdot \mathrm{SA} \cdot \mathrm{AF} \cdot \mathrm{ABS} \cdot \mathrm{EF} \cdot \mathrm{ED}}{\mathrm{BW} \cdot \mathrm{AT}}
$$

where:
$\mathrm{AB}_{\mathrm{s}}=$ amount of contaminant absorbed during contact with soil (mg/kg/day);
$\mathrm{C}_{\mathrm{s}}=$ concentration of constituent in soil $(\mathrm{mg} / \mathrm{kg})$;
$\mathrm{CF}=$ conversion factor $\left(10^{-6} \mathrm{~kg} / \mathrm{mg}\right)$;
$\mathrm{SA}=$ skin surface area available for contact (square centimeter $\left[\mathrm{cm}^{2}\right] /$ event);
$\mathrm{AF}=$ skin adherence factor $\left(\mathrm{mg} / \mathrm{cm}^{2}\right)$;
$\mathrm{ABS}=$ absorption factor (unitless);
$\mathrm{EF}=$ exposure frequency (events/year);
$\mathrm{ED}=$ exposure duration (years);
$\mathrm{BW}=$ body weight $(\mathrm{kg})$; and
$\mathrm{AT}=$ averaging time (days); for noncarcinogens, $\mathrm{AT}=[(\mathrm{ED}),(365$ days/year) $)$; for chemical carcinogens, AT $=[(70$ years $),(365$ days/year $)]$.

\section{A.5.4 Inhalation of Volatiles}

None of the COCs are volatile; therefore, intakes resulting from inhalation of volatile COCs were not estimated.

\section{A.5.5 Inhalation of Particulates}

Intake for inhalation of particulates from soils as a result of outdoor activities by a receptor are estimated using the following equation (EPA, 1991a):

$$
\mathrm{I}_{\mathrm{s}}=\frac{\mathrm{C}_{\mathrm{s}} \cdot \mathrm{IR} \cdot \mathrm{CF} \cdot \mathrm{EF} \cdot \mathrm{ED}}{\mathrm{BW} \cdot \mathrm{AT} \cdot \mathrm{PEF}}
$$

where:

$\mathrm{I}_{\mathrm{S}}=$ intake from soil for contaminant $(\mathrm{mg} / \mathrm{kg} / \mathrm{day})$;

$\mathrm{C}_{\mathrm{s}}=$ concentration of contaminant in soil $(\mathrm{mg} / \mathrm{kg})$;

$\mathrm{IR}=$ inhalation rate $(\mathrm{g} / \mathrm{day})$;

$\mathrm{CF}=$ conversion factor $\left(10^{-6} \mathrm{~kg} / \mathrm{mg}\right)$;

$\mathrm{EF}=$ exposure frequency (days/year); 
$\mathrm{ED}=$ exposure duration (years);

$\mathrm{PEF}=$ particulate emission factor $\left(4.63 \times 10^{9} \mathrm{~m}^{3} / \mathrm{kg}\right)$;

$\mathrm{BW}=$ body weight $(\mathrm{kg})$; and

$\mathrm{AT}=$ averaging time (days); for noncarcinogens, $\mathrm{AT}=[(\mathrm{ED}),(365$ days/year) $]$; for chemical carcinogens, $\mathrm{AT}=[(70$ years $),(365$ days/year $)]$ 


\section{A.6.0 Toxicity Assessment}

Table A.6-1 summarizes the toxicity data for the COCs at the DPF. The following subsections discuss the toxicity assessment for carcinogenic and noncarcinogenic effects along with contaminant-specific issues related to toxicity.

\section{A.6.1 Toxicity Assessment for Carcinogenic and Noncarcinogenic Effects}

Slope factors for carcinogens and reference doses (RfDs) for noncarcinogens were obtained from the Integrated Risk Information System (IRIS) (EPA, 1997), an on-line data base updated monthly, and Health Effects Assessment Summary Tables (HEAST) and supplements (EPA, 1995b), a compilation of nonverified toxicity data, as well as other EPA sources.

\section{A.6.2 Chemical-Specific Issues}

The following chemicals have specific uncertainty issues that may impact the risk assessment.

\section{A.6.2.1 Lead}

There is no RfD for lead. The evaluation of risk from exposure to lead is typically evaluated using the Lead Uptake/Biokinetic Model (EPA, 1994b). The model utilizes data from soil and drinking water to estimate total exposure to a population of children for an estimate of blood lead concentration. This estimate of blood lead is then compared to an acceptable blood lead level for children of 10 micrograms per decaliter $(\mu \mathrm{g} / \mathrm{dL})$. However, this model is only applicable to residential child exposure scenarios. Since this risk assessment evaluates soil only and does not include an evaluation of groundwater lead exposures, the Lead Uptake/Biokinetic Model is not an appropriate model for the evaluation of lead exposures at DPF. Therefore, lead exposures in surface soil will be compared qualitatively to the interim soil-screening level for lead which is 400 milligrams per kilogram $(\mathrm{mg} / \mathrm{kg}$ ) as established by the EPA (1994a). The representative concentration of lead in subsurface soil is $15 \mathrm{mg} / \mathrm{kg}$ and this is significantly less than the interim soil-screening level. Moreover, there is only one exposure scenario involving subsurface soil and this scenario has an adult receptor.

\section{A.6.2.2 Chromium}

Chromium is found in soil in both the ${ }^{+} 3$ and ${ }^{+} 6$ valence states. Chromium in soil has been measured as total chromium and has not been speciated. For the purposes of this risk assessment, chromium will be evaluated as chromium ${ }^{+} 6$. 


\section{A.6.2.3 Total Petroleum Hydrocarbons}

Total Petroleum Hydrocarbon (TPH) compounds are found in soil at oil-contaminated waste sites. Current practice differentiates TPH by molecular chain length. The literature identifies motor oil as one of a number of long-chain hydrocarbons known generally as $\mathrm{C}_{19-32}$ alkenes. The specific reference compound for alkenes is eicosane. The Massachusetts Department of Environmental Protection (MDEP) proposes an alternate oral reference dose of $6.0 \mathrm{mg} / \mathrm{kg} / \mathrm{d}$ for eicosane (MDEP, 1994). This RfD is included in the hazard risk calculation portion of this risk assessment. At this time, there is no proposed carcinogenic toxicity value; therefore, no slope factors were used for TPH in the cancer risk calculations. 
Table A.6-1

Toxicity Data for Contaminants of Concern

\begin{tabular}{|c|c|c|c|c|c|c|}
\hline \multirow[b]{2}{*}{ Chemical } & \multicolumn{3}{|c|}{ Reference Dose } & \multicolumn{3}{|c|}{ Cancer Slope Factor } \\
\hline & $\begin{array}{c}\text { Oral } \\
\text { Exposure } \\
\text { (mg/kg/day) }\end{array}$ & $\begin{array}{c}\text { Inhalation } \\
\text { Exposure } \\
\text { (mg/kg/day) }\end{array}$ & $\begin{array}{c}\text { Noncancer } \\
\text { Target Organ } \\
\text { (Oral/Inhalation) }\end{array}$ & 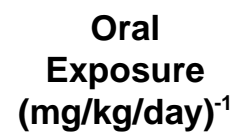 & 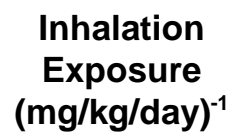 & $\begin{array}{l}\text { Weight of } \\
\text { Evidence and } \\
\text { Target Organ }\end{array}$ \\
\hline \multicolumn{7}{|l|}{ Inorganics } \\
\hline Arsenic & $3.0 \times 10^{-4}(I)^{a}$ & $N A^{b}$ & Skin/NA & $1.5 \times 10^{0}(\mathrm{I})$ & $1.5 \times 10^{1}(\mathrm{I})$ & A/Skin, Lung \\
\hline Chromium VI & $5.0 \times 10^{-3}(\mathrm{I})$ & NA & Kidney/NA & NA & $4.2 \times 10^{1}(\mathrm{I})$ & A/Lung \\
\hline Lead & NA & NA & NA & NA & NA & B2/Kidney \\
\hline \multicolumn{7}{|l|}{ Volatile Organics } \\
\hline \multicolumn{7}{|l|}{ No COPCs } \\
\hline \multicolumn{7}{|l|}{ Semivolatile Organics } \\
\hline Bis(2-ethylhexyl)phthalate & $2.0 \times 10^{-2}(I)$ & NA & Liver/NA & $1.4 \times 10^{-2}(\mathrm{I})$ & NA & B2/Liver \\
\hline Motor oil & $6.0 \times 10^{0}(\mathrm{~S})^{d}$ & $6.0 \times 10^{0}(\mathrm{~S})$ & Liver $/$ NA & NA & NA & NA \\
\hline Waste oil & $6.0 \times 10^{0}(\mathrm{~S})$ & $6.0 \times 10^{0}(\mathrm{~S})$ & Livere/NA & NA & NA & NA \\
\hline \multicolumn{7}{|l|}{ Pesticides/PCBs } \\
\hline Aroclor-1254 & NA & NA & NA & $7.7 \times 10^{0}(\mathrm{I})$ & NA & B2/Liver \\
\hline
\end{tabular}

$a_{1}$ - Value found in Integrated Risk Information System (EPA, 1997)

Not available

EPA Carcinogen Classification:

Group $A=$ Sufficient evidence for carcinogenicity in humans

Group B = Probable human carcinogen (B1 - limited evidence of carcinogenicity in humans; B2 - sufficient evidence of carcinogenicity in animals with inadequate evidence in

humans)

Group C = Possible human carcinogen

Group D = Not classifiable as to human carcinogenicity

Group E = Evidence for noncarcinogenicity in humans

${ }^{d} S$ - Reference doses for motor oil and waste oil are taken from "Interim Final Petroleum Policy: Development of Health-Based Alternative to the Total

Petroleum Hydrocarbon Parameter", Massachusetts Department of Environmental Protection, Document No. 94-1, June, 1994 (MDEP, 1994) for the following surrogate

chemicals: long-chain hydrocarbons $\mathrm{C}_{19-32}$ alkanes, especially eicosane, which is identified as the reference compound.

${ }^{\mathrm{M}}$ MDEP (1994) 


\section{A.7.0 Risk Characterization}

The purpose of the risk characterization step is to integrate exposure and toxicity assessments to generate quantitative expressions of risk. The risk characterization is performed in accordance with EPA risk assessment guidelines (EPA, 1989). Quantitative estimates of carcinogenic risk and noncarcinogenic hazard are calculated for exposures from soil. The exception is lead exposures which was discussed in Section 2.6.

\section{A.7.1 Calculation of Carcinogenic Risk}

Cancer risk is compared to a target risk range of $10^{-6}$ to $10^{-4}$. Total cancer risk from all exposures is summed:

$$
\text { Total Cancer Risk }=\sum \text { Cancer Risk }_{\mathrm{i}}
$$

where:

Total Cancer Risk = total lifetime cancer risk from exposures to all chemicals (unitless);

Cancer Risk $\quad=$ lifetime cancer risk from exposures to chemical contaminant $I$; and $(I=1 \ldots n)$ (unitless).

Cancer risk from exposures to chemical contaminants is estimated using the equation:

$$
\text { Cancer } \operatorname{Risk}_{\mathrm{i}}=\mathrm{I}_{\mathrm{i}} \cdot \mathrm{SF}_{\mathrm{i}}
$$

where:

$$
\begin{array}{ll}
\text { Cancer Risk }_{\mathrm{i}}= & \text { lifetime cancer risk (unitless) from chemical contaminant } I(I=1 \ldots \mathrm{n}) ; \\
= & \text { total daily intake of contaminant } I(I=1 \ldots \mathrm{n}) \text { from indirect exposures } \\
& (\mathrm{mg} / \mathrm{kg} / \mathrm{day}) ; \text { and } \\
\mathrm{I}_{\mathrm{i}} & = \\
\mathrm{SF}_{\mathrm{i}} & \text { slope factor }\left([\mathrm{mg} / \mathrm{kg} / \mathrm{day}]^{-1}\right) \text { for chemical contaminant } I(I=1 \ldots \mathrm{n}) .
\end{array}
$$

\section{A.7.2 Calculation of Noncancer Hazard}

The hazard index (HI) is used to evaluate noncancer hazard for any given target organ. The target $\mathrm{HI}$ is 1 . The total noncancer $\mathrm{HI}$ for a target organ from all exposure pathways is estimated using the equation:

$$
\text { Total } \mathrm{HI}_{\mathrm{k}}=\sum \mathrm{HI}_{\mathrm{k}}
$$


where:

Total $\mathrm{HI}_{\mathrm{k}}=$ total hazard index for individual target organ $k(k=1 . . \mathrm{h})$ (unitless);

$\sum \mathrm{HI}_{\mathrm{k}}=$ sum of all hazard indices with effects in target organ $k(k=1 . . \mathrm{h})$ (unitless).

The hazard quotient (HQ) is used to evaluate noncancer toxicity of chemical contaminants. The HQ represents the ratio of the dose received by the exposed individual to the dose that is associated with no adverse effects (i.e., the threshold or reference dose). The HQs that affect the same target organ (i.e., liver, kidney, etc.) are summed to obtain an HI for an individual target organ. The HI is estimated using the equation:

$$
\mathrm{HI}_{\mathrm{k}}=\sum \mathrm{HQ}_{\mathrm{ik}}
$$

where:

$$
\begin{aligned}
\mathrm{Hi}_{\mathrm{k}}= & \text { hazard index for individual target organ } k(k=1 \ldots \mathrm{h}) \text { (unitless); and } \\
\mathrm{HQ}_{\mathrm{i} \mathrm{k}}= & \text { hazard quotient for chemical } I(I=1 \ldots \mathrm{n}) \text { with effects in target organ } k(k=1 \ldots \mathrm{h}) \\
& \text { (unitless). }
\end{aligned}
$$

The HQ for exposures to chemical contaminants which have noncancer health effects is estimated using the equation below:

$$
\mathrm{HQ}_{\mathrm{i}}=\frac{\mathrm{I}_{\mathrm{i}}}{\mathrm{RfD}_{\mathrm{i}}}
$$

where:

$\mathrm{Hq}_{\mathrm{i}}=$ hazard quotient for chemical $I(I=1 \ldots \mathrm{n})$ (unitless);

$\mathrm{I}_{\mathrm{i}} \quad=$ total daily intake from exposures to chemical contaminant $I(I=1 \ldots \mathrm{n})(\mathrm{mg} / \mathrm{kg} / \mathrm{day})$; and

$\mathrm{RfD}_{\mathrm{i}}=$ reference dose for chemical $I(I=1 \ldots \mathrm{n})(\mathrm{mg} / \mathrm{kg} /$ day $)$.

\section{A.7.3 Human Health Risk Assessment Results}

This section summarizes the results of the human health risk assessment. The discussion includes the selection of COCs for each media and the quantitative risk estimates associated with those COCs. The summary of the quantitative risk estimates (presented in a series of tables with text discussion) includes cancer risk and noncancer hazard, summed for all COCs in each pathway. Total risk for each receptor is also presented. Attachment A.1 contains a complete representation of individual chemical risks for each pathway and receptor presented in individual spreadsheets. 
Tables A.7-1 and A.7-2 summarize selected COCs for surface and subsurface soil associated with the NTS Area 6 Decontamination Pond. Arsenic, motor oil, waste oil, bis(2-ethylhexyl) phthalate, and Aroclor-1254 comprise COCs in surface soil, while arsenic, chromium, lead, waste oil, bis(2-ethylhexyl)phthalate, and Aroclor-1254 comprise COCs in subsurface soil.

\section{A.7.3.1 Carcinogenic Results}

The RME cancer risk is within the target risk range $\left(10^{-6}\right.$ to $\left.10^{-4}\right)$ for surface and subsurface soil exposures (Table A.7-3).

Although within the target risk range, the industrial worker has the highest potential cancer risk from exposure to COCs in the surface soil. The total risk to this receptor is $9 \times 10^{-6}$. All three pathways had risk levels in the $10^{-6}$ range (see Table A.7-3). Arsenic, bis(2-ethylhexyl)phthalate, and Aroclor- 1254 contribute risks of $3 \times 10^{-6}, 1 \times 10^{-6}$, and $5 \times 10^{-7}$, respectively for the ingestion pathway (Attachment A.1).

The total risk to the radiological worker was $3 \times 10^{-7}$, well below the target risk range (Table A.7-3). The ingestion pathway resulted in the greatest risk at $1 \times 10^{-7}$. Arsenic, bis(2-ethylhexyl)phthalate, and Aroclor-1254 contribute risks of $6 \times 10^{-8}, 2 \times 10^{-8}$, and $1 \times 10^{-8}$, respectively for the ingestion pathway (Attachment A.1).

\section{A.7.3.2 Noncarcinogenic Results}

The RME noncancer hazard is within the target risk range $(\mathrm{HI}<1.0)$ (Table A.7-4) for surface and subsurface soil exposures. 
Table A.7-1

Selection of Contaminants of Concern at the DPF, Surface Soil ${ }^{a}$

(Page 1 of 2)

\begin{tabular}{|c|c|c|c|c|c|c|c|c|}
\hline Chemical & $\begin{array}{l}\text { Frequency of } \\
\text { Detection }\end{array}$ & $\begin{array}{c}\text { Maximum Value, } \\
\mathrm{mg} / \mathrm{kg}\end{array}$ & ${ }_{\text {Distribution }}^{\text {Statistical }}$ b & $\begin{array}{c}95 \% \mathrm{UCL}_{\mathrm{C}} \\
\mathrm{mg} / \mathrm{kg}\end{array}$ & $\begin{array}{l}\text { Screening } \\
\text { Criteria } \\
\mathrm{mg} / \mathrm{kg}\end{array}$ & $\begin{array}{l}\text { Exclusion } \\
\text { Rationale }\end{array}$ & $\operatorname{coc}^{f}$ & $\begin{array}{c}\text { Representative } \\
\text { Concentration } \\
\mathrm{mg} / \mathrm{kg}\end{array}$ \\
\hline \multicolumn{9}{|l|}{ Inorganics } \\
\hline Arsenic & 2/2(100) & 5.8 & NA & NA & 0.24 & -- & $\mathrm{Y}$ & 5.8 \\
\hline Barium & $2 / 2(100)$ & 219 & NA & NA & 10000 & $\mathrm{C}$ & $\mathrm{N}$ & -- \\
\hline Cadmium & $2 / 2(100)$ & 1.5 & NA & NA & 85 & $\mathrm{C}$ & $\mathrm{N}$ & -- \\
\hline Chromium & $2 / 2(100)$ & 18.7 & NA & NA & 23 & $\mathrm{C}$ & $\mathrm{N}$ & -- \\
\hline Lead & $2 / 2(100)$ & 52.1 & NA & NA & $1.4 \times 10^{3 \mathrm{~h}}$ & $\mathrm{C}$ & $\mathrm{N}$ & -- \\
\hline \multicolumn{9}{|c|}{ Volatile Organic Compounds } \\
\hline 2-butanone & $1 / 22(5)$ & 0.024 & NP & 0.024 & 2700 & $\mathrm{~B}, \mathrm{C}$ & $\mathrm{N}$ & -- \\
\hline Acetone & 19/22(86) & 0.27 & L & 0.104477 & 880 & C & $\mathrm{N}$ & -- \\
\hline Benzene & $1 / 22(5)$ & 0.004 & NP & 0.004 & 0.14 & $\mathrm{~B}, \mathrm{C}$ & $\mathrm{N}$ & -- \\
\hline Methylene Chloride & 2/22(9) & 0.005 & NP & 0.005 & 1.8 & $\mathrm{C}$ & $\mathrm{N}$ & -- \\
\hline Motor Oil & $12 / 20(60)$ & 21000 & $U$ & 5400 & $100^{\mathrm{i}}$ & -- & $\mathrm{Y}$ & 5400 \\
\hline Styrene & $3 / 22(14)$ & 0.007 & NP & 0.004 & 68 & $\mathrm{C}$ & $\mathrm{N}$ & -- \\
\hline Toluene & $1 / 22(5)$ & 0.003 & NP & 0.003 & 88 & $B, C$ & $\mathrm{~N}$ & -- \\
\hline Waste Oil & $2 / 2(100)$ & 1300 & NA & NA & $100^{\mathrm{i}}$ & -- & $\mathrm{Y}$ & 1300 \\
\hline
\end{tabular}


Table A.7-1

\section{Selection of Contaminants of Concern at the DPF, Surface Soil ${ }^{\mathrm{a}}$}

(Page 2 of 2)

\begin{tabular}{|c|c|c|c|c|c|c|c|c|}
\hline Chemical & $\begin{array}{l}\text { Frequency of } \\
\text { Detection }\end{array}$ & $\begin{array}{c}\text { Maximum Value, } \\
\mathrm{mg} / \mathrm{kg}\end{array}$ & $\begin{array}{l}\text { Statistical } \\
\text { Distribution }\end{array}$ & $\begin{array}{l}95 \% \mathrm{UCL}^{-} \\
\mathrm{mg} / \mathrm{kg}\end{array}$ & $\begin{array}{l}\text { Screening } \\
\text { Criteria } \\
\mathrm{mg} / \mathrm{kg}\end{array}$ & $\begin{array}{l}\text { Exclusion } \\
\text { Rationale }\end{array}$ & $\operatorname{coc}^{f}$ & $\begin{array}{c}\text { Representative } \\
\text { Concentration } \\
\mathrm{mg} / \mathrm{kg} g\end{array}$ \\
\hline \multicolumn{9}{|c|}{ Semivolatile Organic Compounds } \\
\hline Bis(2-ethylhexyl)phthalate & $15 / 22(68)$ & 240 & L & 1193 & 14 & -- & $\mathrm{Y}$ & 240 \\
\hline Butyl Benzyl Phthalate & $6 / 22(27)$ & 25 & NP & 0.16 & 93 & $\mathrm{C}$ & $\mathrm{N}$ & -- \\
\hline Di-n-butyl Phthalate & 1/22(5) & 1.5 & NP & 1.5 & 6800 & $\mathrm{~B}, \mathrm{C}$ & $\mathrm{N}$ & -- \\
\hline Di-n-octyl Phthalate & $11 / 22(50)$ & 4.1 & $U$ & 1.4 & 1000 & C & $\mathrm{N}$ & -- \\
\hline Phenanthrene & $1 / 22(5)$ & 1 & NP & 1 & NA & $\mathrm{B}$ & $\mathrm{N}$ & -- \\
\hline \multicolumn{9}{|l|}{ Pesticides/PCBs } \\
\hline Aroclor-1254 & $13 / 22(59)$ & 2 & $\mathrm{U}$ & 0.21 & 1.9 & -- & $\mathrm{Y}$ & 0.21 \\
\hline \multicolumn{9}{|l|}{ Herbicides } \\
\hline No samples collected & & & & & & & & \\
\hline
\end{tabular}

${ }^{a}$ Surface soil is defined as the interval less than 0.5 feet below the ground surface (bgs).

Statistical Distribution: $N=$ Normal distribution; $L=$ Lognormal distribution; $U=$ undetermined distribution; $N P=$ nonparametric distribution for datasets with greater than $50 \%$ nondetects; $\mathrm{NA}=$ distribution not determined if sample size is less than or equal to 5.

95\% Upper confidence limit calculated for the indicated distribution. NA = sample size is less than or equal to 5 and distribution is not calculated.

Toxicity/concentration screen based on an order of magnitude decrement (i.e., $\mathrm{x} 0.1$ ) in the industrial soil preliminary remediation goals developed by EPA Region IX (EPA, 1996).

Rational for exclusion of chemical as a contaminant of concern (COC):

$A=$ within background concentration

$B=$ detection frequency less than $5 \%$.

$\mathrm{C}=$ maximum detection is less than screening criteria

${ }^{\mathrm{f}} \mathrm{N}=$ Chemical is not chosen as a COC; $\mathrm{Y}=$ chemical is chosen as COC.

${ }_{9}^{9}$ Concentration used in risk assessment equal to $95 \%$ UCL or maximum value, if maximum value is less than UCL or if no UCL is calculated.

Screening criteria for lead based on consensus value of $1414 \mathrm{mg} / \mathrm{kg}$.

Nevada Administrative Code 459.9973 (NAC, 1990) 
Table A.7-2

Selection of Contaminants of Concern at the DPF, Subsurface Soil ${ }^{\mathrm{a}}$

(Page 1 of 2)

\begin{tabular}{|c|c|c|c|c|c|c|c|c|}
\hline Chemical & $\begin{array}{l}\text { Frequency of } \\
\text { Detection }\end{array}$ & $\begin{array}{l}\text { Maximum } \\
\text { Value, } \\
\mathrm{mg} / \mathrm{kg}\end{array}$ & $\underset{\text { Distribution }}{\text { Statistical }}$ & $\begin{array}{c}95 \% \mathrm{UCL}_{\mathrm{C}} \\
\mathrm{mg} / \mathrm{kg}\end{array}$ & $\begin{array}{c}\text { Screening } \\
\text { Criteria } \\
\mathrm{mg} / \mathrm{kg}\end{array}$ & $\begin{array}{l}\text { Exclusion } \\
\text { Rationale }\end{array}$ & $\operatorname{coc}^{f}$ & $\begin{array}{c}\text { Representative } \\
\text { Concentration } \\
\mathrm{mg} / \mathrm{kg}^{\mathrm{g}}\end{array}$ \\
\hline \multicolumn{9}{|l|}{ Inorganics } \\
\hline Arsenic & $46 / 46(100)$ & 23.7 & $U$ & 6.1 & 0.24 & -- & $\mathrm{Y}$ & 6.1 \\
\hline Barium & $46 / 46(100)$ & 1360 & $U$ & 210 & 10000 & $\mathrm{C}$ & $\mathrm{N}$ & -- \\
\hline Cadmium & $26 / 46(57)$ & 14.9 & $U$ & 0.19 & 85 & $\mathrm{C}$ & $\mathrm{N}$ & -- \\
\hline Chromium & $46 / 46(100)$ & 44.8 & $U$ & 14.1 & 23 & -- & $\mathrm{Y}$ & 14.1 \\
\hline Lead & $46 / 46(100)$ & 2170 & $U$ & 15.2 & $1.4 \times 10^{3 \mathrm{~h}}$ & -- & $\mathrm{Y}$ & 15.2 \\
\hline Mercury & $2 / 46(4)$ & 0.19 & NP & 0.08 & 51 & $\mathrm{~B}, \mathrm{C}$ & $\mathrm{N}$ & -- \\
\hline Silver & $2 / 46(4)$ & 2.8 & NP & 1.4 & 850 & $\mathrm{~B}, \mathrm{C}$ & $\mathrm{N}$ & -- \\
\hline \multicolumn{9}{|c|}{ Volatile Organic Compounds } \\
\hline 2-butanone & $1 / 92(1)$ & 0.02 & NP & 0.02 & 2700 & $\mathrm{~B}, \mathrm{C}$ & $\mathrm{N}$ & -- \\
\hline Acetone & $44 / 92(48)$ & 0.56 & NP & 0.004 & 880 & $\mathrm{C}$ & $\mathrm{N}$ & -- \\
\hline Carbon Disulfide & 2/92(2) & 0.004 & NP & 0.003 & 2.4 & $\mathrm{~B}, \mathrm{C}$ & $\mathrm{N}$ & -- \\
\hline Chlorobenzene & 2/92(2) & 0.018 & NP & 0.012 & 22 & $\mathrm{~B}, \mathrm{C}$ & $\mathrm{N}$ & -- \\
\hline Chloroform & $1 / 92(1)$ & 0.001 & NP & 0.001 & 0.053 & $\mathrm{~B}, \mathrm{C}$ & $\mathrm{N}$ & -- \\
\hline Chloromethane & $1 / 92(1)$ & 0.006 & NP & 0.006 & 0.26 & $\mathrm{~B}, \mathrm{C}$ & $\mathrm{N}$ & -- \\
\hline Methylene Chloride & $34 / 92(37)$ & 0.039 & NP & 0.001 & 1.8 & C & $\mathrm{N}$ & -- \\
\hline Toluene & $15 / 92(16)$ & 0.004 & NP & 0.001 & 88 & $\mathrm{C}$ & $\mathrm{N}$ & -- \\
\hline Trichloroethylene & $1 / 92(1)$ & 0.002 & NP & 0.002 & 0.7 & $\mathrm{~B}, \mathrm{C}$ & $\mathrm{N}$ & -- \\
\hline
\end{tabular}


Table A.7-2

Selection of Contaminants of Concern at the DPF, Subsurface Soil ${ }^{\mathrm{a}}$

(Page 2 of 2)

\begin{tabular}{|c|c|c|c|c|c|c|c|c|}
\hline Chemical & $\begin{array}{l}\text { Frequency of } \\
\text { Detection }\end{array}$ & $\begin{array}{c}\text { Maximum } \\
\text { Value, } \\
\mathrm{mg} / \mathrm{kg}\end{array}$ & $\begin{array}{c}\text { Statistical } \\
\text { Distribution }\end{array}$ & $\begin{array}{l}95 \% \mathrm{UCL}_{\mathrm{C}} \\
\mathrm{mg} / \mathrm{kg}\end{array}$ & $\begin{array}{c}\text { Screening } \\
\text { Criteria } \\
\mathrm{mg} / \mathrm{kg}\end{array}$ & $\begin{array}{l}\text { Exclusion } \\
\text { Rationale }\end{array}$ & $\operatorname{coc}^{f}$ & $\begin{array}{c}\text { Representative } \\
\text { Concentration } \\
\mathrm{mg} / \mathrm{kg}^{\mathrm{g}}\end{array}$ \\
\hline Waste Oil & $6 / 79(8)$ & 2000 & NP & 0.047 & $100^{i}$ & -- & $\mathrm{Y}$ & 0.047 \\
\hline Xylene (Total) & $1 / 92(1)$ & 0.003 & NP & 0.003 & 32 & $\mathrm{~B}, \mathrm{C}$ & $\mathrm{N}$ & -- \\
\hline \multicolumn{9}{|c|}{ Semivolatile Organic Compounds } \\
\hline Bis(2-ethylhexyl)phthalate & $31 / 69(45)$ & 150 & NP & 0.13 & 14 & -- & $\mathrm{Y}$ & 0.13 \\
\hline Butyl Benzyl Phthalate & $1 / 69(1)$ & 11 & NP & 11 & 93 & $\mathrm{~B}, \mathrm{C}$ & $\mathrm{N}$ & -- \\
\hline Di-n-octyl Phthalate & $4 / 69(6)$ & 17 & NP & 0.28 & 1000 & C & $\mathrm{N}$ & -- \\
\hline \multicolumn{9}{|l|}{ Pesticides/PCBs } \\
\hline Aroclor-1254 & $4 / 46(9)$ & 2.6 & NP & 0.063 & 1.9 & -- & $\mathrm{Y}$ & 0.063 \\
\hline Aroclor-1260 & $1 / 46(2)$ & 0.38 & NP & 0.38 & 0.034 & B & $\mathrm{N}$ & -- \\
\hline \multicolumn{9}{|l|}{ Herbicides } \\
\hline No samples collected & & & & & & & & \\
\hline
\end{tabular}

${ }_{b}^{a}$ Surface soil is defined as the interval less than 0.5 feet below the ground surface.

Statistical Distribution: $\mathrm{N}=$ Normal distribution; $\mathrm{L}=$ Lognormal distribution; $\mathrm{U}=$ undetermined distribution; $\mathrm{NP}=$ nonparametric distribution for datasets with greater than $50 \%$ nondetects; NA = distribution not determined if sample size is less than or equal to 5 .

c95\% Upper confidence limit calculated for the indicated distribution. NA = sample size is less than or equal to 5 and distribution is not calculated.

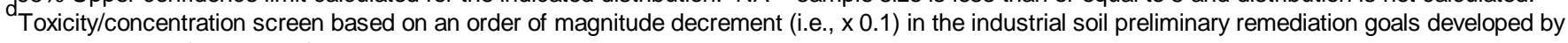
EPA Region IX (EPA, 1996).

Rational for exclusion of chemical as a contaminant of potential concern (COC):

$\mathrm{A}=$ within background concentration.

$\mathrm{B}=$ detection frequency less than $5 \%$.

$\mathrm{C}=$ maximum detection is less than screening criteria.

${ }^{\mathrm{f}} \mathrm{N}=$ Chemical is not chosen as a COC; $\mathrm{Y}=$ chemical is chosen as COC.

${ }_{9}^{9}$ Concentration used in risk assessment equal to $95 \%$ UCL or maximum value, if maximum value is less than UCL or if no UCL is calculated.

Screening criteria for lead based on consensus value of $1414 \mathrm{mg} / \mathrm{kg}$

Nevada Administrative Code 459.9973 (NAC, 1990) 
Table A.7-3

Cancer Risk Estimates at the DPF

\begin{tabular}{||c|c|c||}
\hline \multirow{2}{*}{\multicolumn{1}{c|}{ Pathway }} & \multicolumn{2}{|c||}{ Receptor } \\
\cline { 2 - 3 } & Radiological Worker & Industrial Worker \\
\hline \hline Ingestion & $9 \times 10^{-8}$ & $4 \times 10^{-6}$ \\
\hline Particulate Inhalation & $4 \times 10^{-8}$ & $2 \times 10^{-6}$ \\
\hline Dermal & $1 \times 10^{-8}$ & $3 \times 10^{-6}$ \\
\hline \multicolumn{1}{|c|}{ TOTAL } & $\mathbf{3 \times 1 0 ^ { - 7 }}$ & $\mathbf{9 \times 1 0 ^ { - 6 }}$ \\
\hline
\end{tabular}

Table A.7-4

Noncancer Risk Estimate for the DPF

\begin{tabular}{|c|c|c|}
\hline \multirow{2}{*}{ Pathway } & \multicolumn{2}{|c|}{ Receptor } \\
\hline & Radiological Worker & Industrial Worker \\
\hline Ingestion & $7 \times 10^{-4}$ & $2 \times 10^{-2}$ \\
\hline Particulate Inhalation & $2 \times 10^{-5}$ & $8 \times 10^{-4}$ \\
\hline Dermal & $8 \times 10^{-4}$ & $3 \times 10^{-2}$ \\
\hline TOTAL & $2 \times 10^{-3}$ & $5 \times 10^{-2}$ \\
\hline
\end{tabular}

Although within the target risk range, the industrial worker has the highest potential noncancer hazard from exposure to COCs in the surface soil. The total hazard to this receptor is $5 \times 10^{-2}$ (Table A.7-4). The surface soil ingestion and dermal adsorption pathways each had total risks of $3 \times 10^{-2}$, with bis(2-ethylhexyl)phthalate contributing a risk of $1 \times 10^{-2}$ (Table A.7-4 and Attachment A.1). The other COCs have risks less than the $10^{-2}$ level.

The total hazard to the radiological worker is $2 \times 10^{-3}$. The ingestion pathway contributes a risk of $1 \times 10^{-3}$. However, no single COC has a risk in the $10^{-3}$ range.

\section{A.7.4 Conclusion}

In conclusion, the RME cancer and noncancer risks were well within target risk ranges for all receptors and exposure scenarios. Arsenic provided the highest cancer and noncancer risks. However, these risks were well within their target risk range. 


\section{A.8.0 Uncertainty Assessment}

Calculated risk estimates are subject to varying degrees of uncertainty from a variety of sources. Areas of uncertainty in a risk assessment can be categorized as methodological or site-specific. Methodological uncertainties are those that are inherent to the methods or procedures used for risk assessments, that is, policy decisions made to reflect EPA's desire to err on the side of conservatism. Site-specific areas of uncertainty exhibit characteristics of the site or the investigation of the site that could result in overestimates or underestimates of risk. The assessment of uncertainty is qualitative. The most significant sources of uncertainty in the risk assessment will be itemized and evaluated for their potential to contribute to either the over- or underestimation of risk. Specific areas of uncertainty are discussed in following sections.

\section{A.8.1 Methodological Uncertainty}

There are four major areas of methodological uncertainty: uncertainty in the estimation of contaminant concentration, uncertainty in the estimation of exposure, uncertainty in the estimation of toxicity, and uncertainty in the estimation of risk.

\section{A.8.1.1 Contaminant Concentration}

The complete characterization of the nature and extent of contamination at any site is not possible. In selecting COCs and in estimating concentrations, uncertainties arise from limits on the number and locations of environmental samples that can be collected to characterize a site and from eliminating constituents that are infrequently detected. These limitations may tend to overor underestimate risk. The use of the 95 percent UCL of average contaminant concentrations or maximum-detected concentrations tend toward a conservative, health-protective bias.

\section{A.8.1.2 Exposure Assessment}

Standard assumptions for population characteristics, such as body weight or life expectancy, and exposure characteristics, such as frequency, duration, amount of intake, or contact, may not represent actual exposure conditions. Standard exposure assumptions are used to characterize residential groundwater exposures. The assumption that a worker will be at the decontamination pond for 20 years is generally recognized as an overestimation of exposure.

An attempt has been made to reflect site-specific exposure estimates in the characterization of soil exposures to workers and potential residents while maintaining a level of conservatism. 
Therefore, the magnitude of over- or under-estimation of risk from soil exposures is expected to be minimal.

\section{A.8.1.3 Toxicity Assessment}

The principal uncertainties associated with the toxicity assessment are:

- Extrapolation of toxic effects observed at the high doses necessary to conduct animal studies to effects that might occur at much lower, "real-world" doses

- Extrapolation from toxic effects in animals to toxic effects in man.

For noncancer effects, these uncertainties are given numerical value by using an uncertainty factor, which is actually a product of as many as five separate factors, each intended to account for one type of uncertainty (EPA, 1997). For cancer effects, the uncertainty is addressed by estimating the 95 percent upper bound on the slope of the dose-response curve (EPA, 1997). Utilizing the guidance of the EPA will minimize uncertainties by using EPA-derived toxicity values to evaluate the risks posed by constituents. The basis of EPA policy in the derivation of toxicity values is to err on the side of conservatism which may tend to overestimate risk. However, uncertainties associated with the lack of published toxicity data on many constituents would tend to balance any overestimation of risk by tending to underestimate risk from these constituents.

\section{A.8.1.4 Risk Characterization}

The adjustment of slope factors (SFs) and RfDs for use in calculations for dermal risk may present some uncertainty, although the adjustment would likely result in a conservative estimate. Risk is assumed to be additive for chemicals with similar sites of toxicological action. In the event that any combinations of these chemicals result in multiplicative effects, risk may be underestimated.

\section{A.8.2 Site-Specific Uncertainties}

Site-specific uncertainties can be categorized into two major areas: analytical methodology and background. Each of these areas are discussed in the context of the impact on risk assessment.

- Analytical Methodology: Some uncertainty may be introduced by combining the datasets from multiple investigations. The impact on the risk assessment is expected to be minimal because the investigations occurred during a relatively short time period. 
- Background: Background concentrations of inorganics were not available for this risk assessment. Consequently, risk may have been overestimated because some of the inorganics may be present at background levels. However, the effect in this case is minimal since all risk and hazard is within the target-risk range.

A risk assessment of a site is ultimately an integrated evaluation of historical, chemical, analytical, environmental, demographic, and toxicological data that are as site-specific as possible. To minimize the possibility of underestimating risk, each step is biased toward health-protective estimations. Because each step builds on the previous one, this biased approach mathematically compounds, and should more than compensate for risk assessment uncertainties that underestimate true risk. In addition, these calculations do not represent currently existing or expected future-exposure or health risks. Rather, they are estimates of potential risk only if all of the conservative exposure assumptions are realized. This risk assessment does not represent a worst-case scenario, therefore, the potential for underestimating some risks to some receptors, however unlikely, does exist. 


\section{A.9.0 References}

DOE, see U.S. Department of Energy.

EPA, see U.S. Environmental Protection Agency.

Gilbert, R.O. 1987. Statistical Methods for Environmental Pollution Monitoring. Van Nostrand Reinhold: New York, NY.

MDEP, see Massachusetts Department of Environmental Protection.

Massachusetts Department of Environmental Protection. 1994. "Interim Final Petroleum Policy: Development of Health-Based Alternative to the Total Petroleum Hydrocarbon Parameter," Document No. 94-1, June 1994. Springfield, MA.

NAC, see Nevada Administrative Code.

Nevada Administrative Code. 1990. NAC 459.9973, “Action by Division When Excessive Petroleum is Present in Soil." Carson City, NV.

U.S. Environmental Protection Agency. 1989. Risk Assessment Guidance for Superfund, Vol. 1: Human Health Evaluation Manual, Part A, EPA/540/1-89/002. Washington, DC: Office of Emergency and Remedial Response.

U.S. Environmental Protection Agency. 1991a. Risk Assessment Guidance for Superfund, Vol. 1: Human Health Evaluation Manual, Part B, Development of Risk-Based Preliminary Remediation Goals. Washington, DC: Office of Emergency and Remedial Response.

U.S. Environmental Protection Agency. 1991b. Risk Assessment Guidance for Superfund, Vol. 1: Human Health Evaluation Manual, Supplemental Guidance: Dermal Risk Assessment Interim Guidance. Washington, DC: Office of Emergency and Remedial Response.

U.S. Environmental Protection Agency. 1992. Supplemental Guidance to RAGS: Calculating the Concentration Term, Publication \#9285.7-081. Washington, DC: Office of Emergency and Remedial Response.

U.S. Environmental Protection Agency. 1993. Selecting Exposure Routes and Contaminants of Concern by Risk-Based Screening, EPA/903/R-93/001. Philadelphia, PA: Hazardous Waste Management Division, Office of Superfund, Region III.

U.S. Environmental Protection Agency. 1994a. Revised Interim Soil Lead Guidance for CERCLA Sites and RCRA Corrective Action Facilities (OSWER Directive \#9355.4-12), EPA/540/F-94/043. Washington, DC: Office of Solid Waste and Emergency Response. 
U.S. Environmental Protection Agency. 1994b. Uptake/Biokinetic Model, Version 0.99. Cincinnati, OH: Office of Health and Environmental Assessment.

U.S. Environmental Protection Agency. 1995a. Draft Exposure Factors Handbook, EPA/600/P-95/002A. Washington, DC: Office of Health and Environmental Assessment.

U.S. Environmental Protection Agency. 1995b. Health Effects Assessment Summary Tables (HEAST), EPA/540/R-93/058 and supplements. Washington, DC: Office of Emergency and Remedial Response.

U.S. Environmental Protection Agency. 1996. Region IX Preliminary Remediation Goals. San Francisco, CA.

U.S. Environmental Protection Agency. 1997. Integrated Risk Information System (IRIS). Washington, DC: Office of Health and Environmental Assessment. 
RCRA DPF CAU 92

Appendix A, Attachment A.1

Revision: 0

Date: 10/31/97

Page A-27 of A-31

\section{Attachment A.1}

\section{Risk Calculation Tables}


Table 1

Radiological Worker Cancer Risk from Exposure to COCs in Area 6 DPF

\begin{tabular}{|c|c|c|c|c|c|c|c|c|c|c|c|c|}
\hline \multirow[b]{2}{*}{ Chemkcal Name } & \multirow[b]{2}{*}{$\begin{array}{c}\text { Concentration } \\
\text { in soil (CS) } \\
\text { (mg/kg) }\end{array}$} & \multicolumn{3}{|c|}{$\begin{array}{l}\text { Cancer Polency Factors } \\
1 / t(\mathrm{mg} / \mathrm{kg}-\mathrm{d})\end{array}$} & \multirow{2}{*}{\multicolumn{2}{|c|}{$\begin{array}{c}\text { Absorplion } \\
\text { factor(funitless) }\end{array}$}} & \multicolumn{2}{|c|}{ Dormal Absorption } & \multicolumn{2}{|c|}{$\begin{array}{c}\text { Inhalalion } \\
\text { from soil dust }\end{array}$} & \multicolumn{2}{|c|}{ Ingestion } \\
\hline & & $\begin{array}{c}\text { Oral } \\
\text { Slope } \\
\text { Factor (SFO) } \\
\end{array}$ & \begin{tabular}{|c|} 
Dermal \\
Slope \\
Factor (SFO) \\
\end{tabular} & $\begin{array}{c}\text { Inhalation } \\
\text { Slope } \\
\text { Factor (SFI) }\end{array}$ & & & $\begin{array}{c}\text { Amoumt } \\
\text { Absorted (IDD) } \\
\text { (mokg-d) }\end{array}$ & $\begin{array}{c}\text { Lifatimo } \\
\text { Risks (CRD) } \\
\text { (Unitless) }\end{array}$ & $\begin{array}{c}\text { Amount } \\
\text { Inhaled (IDIS) } \\
\text { (mg/kg-d) }\end{array}$ & $\begin{array}{c}\text { Lifetirne } \\
\text { Risks (CRIS) } \\
\text { (unitless) } \\
\end{array}$ & $\begin{array}{c}\text { Amount } \\
\text { Ingested (IDGG } \\
\text { (mogkg-d) }\end{array}$ & $\begin{array}{c}\text { Lifotime } \\
\text { Risks (CRIG) } \\
\text { (Unitless) }\end{array}$ \\
\hline $\begin{array}{l}\text { INORGANIC CHEMICALS } \\
\text { Arsenic }\end{array}$ & $5.8 \mathrm{E}+\infty 0$ & $15 E+\infty$ & $19 E+100$ & $15 E+01$ & 0.8 & 0.03 & $23 \mathrm{E}-0 \mathrm{~B}$ & 4.4E-08 & 2.2E-09 & 3. $3 \mathrm{E}-0 \mathrm{~B}$ & $3.9 E-08$ & $5.8 E-08$ \\
\hline $\begin{array}{l}\text { SEMIVOLATILE ORGANIC CHEMICALS } \\
\text { Bist2-ethylhexyl)phthatate } \\
\text { Motor oil } \\
\text { Waste oil }\end{array}$ & $\begin{array}{l}2.4 E+02 \\
5.4 E+03 \\
1.3 E+03\end{array}$ & $1.4 E-02$ & $94 E-02$ & $1.4 \mathrm{E}-02$ & $\begin{array}{l}1 \\
1 \\
1\end{array}$ & $\begin{array}{l}0.10 \\
0.10 \\
0.10\end{array}$ & $\begin{array}{l}3.2 E-06 \\
7.2 E-05 \\
1.7 E-05\end{array}$ & 4.5E-08 & $\begin{array}{l}9.0 E-08 \\
2.0 E-06 \\
4.9 E-07\end{array}$ & 1.3E-09 & $\begin{array}{l}16 E-06 \\
3.6 E-05 \\
8.7 E-06\end{array}$ & 2.3E-0B \\
\hline $\begin{array}{l}\text { PESTICIOES/PCBs } \\
\text { Aroclor-1254 } \\
\text { Total Cuncer Risk }\end{array}$ & 2.1E-01 & $7.7 E+\infty$ & $7.7 E+000$ & $77 E+\infty 0$ & 1 & 0.06 & 1.7E-09 & $\frac{1.3 \mathrm{E}-0 \mathrm{~B}}{1.0 \mathrm{E}-07}$ & $7.9 E-11$ & $\frac{6.1 E-10}{3.5 E-08}$ & $14 E-09$ & $\frac{1.1 E-08}{9.2 E-08}$ \\
\hline
\end{tabular}


Table 2

Radiological Worker Noncancer Risk from Exposure to COCs in Area 6 DPF

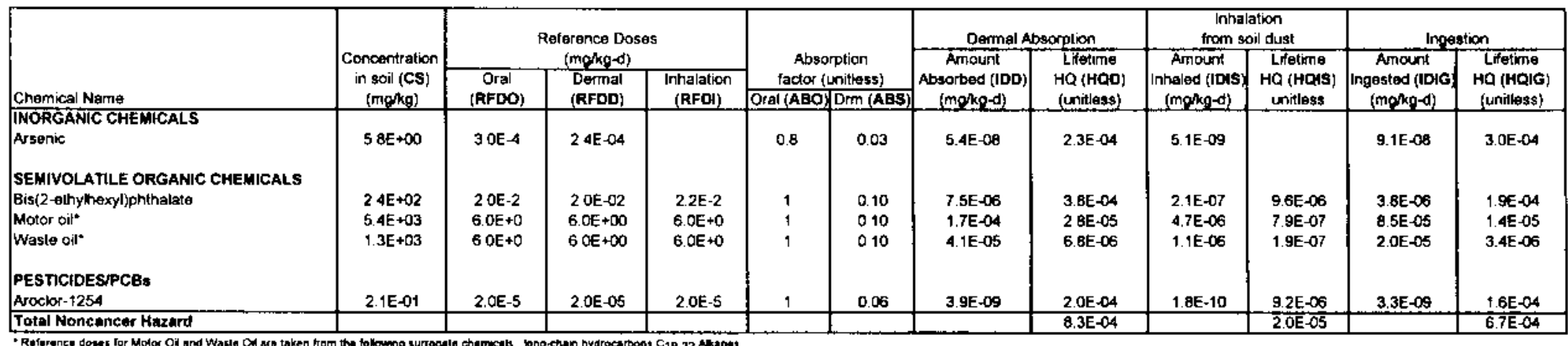

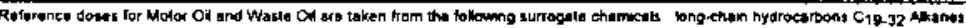


Table 3

Industrial Worker Cancer Risk from Exposure to COCs in Area 6 DPF

\begin{tabular}{|c|c|c|c|c|c|c|c|c|c|c|c|c|}
\hline \multirow{2}{*}{$\begin{array}{l}\text { Cherrical Name } \\
\text { INORGANIC CHEMICALS }\end{array}$} & \multirow[b]{2}{*}{$\begin{array}{c}\text { Concentration } \\
\text { in soil (CS) } \\
\text { (mokg) }\end{array}$} & \multicolumn{3}{|c|}{$\begin{array}{c}\text { Cancer Polency Factors } \\
1 f(\mathrm{mg} / \mathrm{kg}-\mathrm{d})\end{array}$} & \multirow{2}{*}{\multicolumn{2}{|c|}{$\begin{array}{l}\text { Absorplion } \\
\text { factor \{unitless\}) }\end{array}$}} & \multicolumn{2}{|c|}{ Dermal Absorption } & \multicolumn{2}{|c|}{$\begin{array}{c}\text { Inhalalion } \\
\text { from soil dus! }\end{array}$} & \multicolumn{2}{|c|}{ Inggestion } \\
\hline & & \begin{tabular}{|c|} 
Oral \\
Stope \\
Factor (SFO) \\
\end{tabular} & \begin{tabular}{|c|} 
Demal \\
Slope \\
Factor (SFD)
\end{tabular} & $\begin{array}{c}\text { Inhalation } \\
\text { Siope } \\
\text { Factor (SFI) }\end{array}$ & & & \begin{tabular}{|c|} 
Ambunt \\
Absorbod (IDD) \\
(mgikg-d)
\end{tabular} & $\begin{array}{l}\text { Lifelime } \\
\text { Risks (CRD) } \\
\text { (unitless) }\end{array}$ & $\begin{array}{c}\text { Amount } \\
\text { Inhaled (IDIS } \\
\text { (molkg-d) }\end{array}$ & \begin{tabular}{|c|} 
Lifelime \\
Risks (CRIS) \\
(unitless)
\end{tabular} & $\begin{array}{c}\text { Amount } \\
\text { Ingested (101G } \\
\text { (mgkg-d) }\end{array}$ & $\begin{array}{c}\text { Lifetime } \\
\text { Risks (CRIG) } \\
\text { (Unilless) }\end{array}$ \\
\hline $\begin{array}{l}\text { INORGANIC CHEMICALS } \\
\text { Arsentic }\end{array}$ & $5.8 E+\infty$ & $15 E+00$ & $1.9 E+\infty$ & $1.5 E+01$ & 0.8 & 0.03 & 7 3E-O7 & 1.4E-06 & $9.2 \mathrm{E}-0 \mathrm{a}$ & $1.4 E-06$ & 1.2E-06 & $1.8 E-06$ \\
\hline $\begin{array}{l}\text { SEMIVOLATLE ORGANIC CHEMICALS } \\
\text { Qis(2-athythexyl)phthalate } \\
\text { Motor oll } \\
\text { Waste oil }\end{array}$ & $\begin{array}{l}2.4 E+02 \\
5.4 E+03 \\
1.3 E+03\end{array}$ & $14 E-02$ & $1.4 \mathrm{E}-02$ & $1.4 \mathrm{E}-02$ & $\begin{array}{l}1 \\
1 \\
1\end{array}$ & $\begin{array}{l}0.10 \\
0.10 \\
0.10\end{array}$ & $\begin{array}{l}10 E-04 \\
2.3 E-03 \\
5.5 E-04\end{array}$ & $1.4 E-06$ & $\begin{array}{l}\text { 3. } 8 E-06 \\
86 E-05 \\
2.1 E-05\end{array}$ & $5.3 E-08$ & $\begin{array}{l}5.0 E-05 \\
1.1 E-03 \\
2.7 E-04\end{array}$ & $7.0 \mathrm{E}-07$ \\
\hline $\begin{array}{l}\text { PESNICIDESIPCBs } \\
\text { Aroclor-1254 } \\
\text { Total CancEr Risk }\end{array}$ & 2.1E-01 & $7.7 \mathrm{E}+00$ & $7.7 \mathrm{E}+\infty$ & $7.7 E+\infty$ & 1 & 0.06 & $5.3 E-00$ & $\frac{4.1 E-07}{3.2 E-00}$ & $33 \mathrm{E}-09$ & $\begin{array}{r}2.6 E-O 8 \\
-\frac{15 E-08}{2}\end{array}$ & 4.4E- -08 & $\frac{3.4 E-07}{2.5-06}$ \\
\hline
\end{tabular}


Table 4

Industrial Worker Noncancer Risk from Exposure to COCs in Area 6 DPF

\begin{tabular}{|c|c|c|c|c|c|c|c|c|c|c|c|c|}
\hline \multirow{3}{*}{ Chemical Name } & \multirow{3}{*}{$\begin{array}{c}\text { Concentration } \\
\text { in soir (CS) } \\
\text { (mgkg) }\end{array}$} & \multirow{2}{*}{\multicolumn{3}{|c|}{$\begin{array}{c}\text { Reference Doses } \\
\text { (mgke-d) }\end{array}$}} & \multirow{3}{*}{\multicolumn{2}{|c|}{$\begin{array}{c}\text { Absorplion } \\
\text { factor (unitless) } \\
\end{array}$}} & \multicolumn{2}{|c|}{ Dermal Absorption } & \multicolumn{2}{|c|}{$\begin{array}{l}\text { inhalation } \\
\text { from soil dusl }\end{array}$} & \multicolumn{2}{|c|}{ Inpestion } \\
\hline & & & & & & & \multirow{2}{*}{$\begin{array}{c}\text { Amount } \\
\text { Absorbed (IDD) } \\
\text { (mgkgo-d) }\end{array}$} & \multirow{2}{*}{$\begin{array}{l}\text { Lifetime } \\
\text { HQ (HOD) } \\
\text { (unitess) }\end{array}$} & \multirow{2}{*}{$\begin{array}{c}\text { Amount } \\
\text { inhaled (IOS) } \\
(\mathrm{mg} / \mathrm{kg}-\mathrm{d})\end{array}$} & \multirow{2}{*}{$\begin{array}{c}\text { Lifelime } \\
\text { HQ (HOIS) } \\
\text { unilloss }\end{array}$} & \multirow{3}{*}{\begin{tabular}{|c|} 
Amoum! \\
Ingested $\{101 \mathrm{G}$ \\
(mg/kg-d) \\
\end{tabular}} & \multirow{2}{*}{$\begin{array}{l}\text { Lifatime } \\
\text { HQ (HOHG) } \\
\text { (Unilless) }\end{array}$} \\
\hline & & $\begin{array}{c}\text { Oral } \\
\text { RFDO }\end{array}$ & $\begin{array}{l}\text { Dermal } \\
\text { (RFDD) }\end{array}$ & $\begin{array}{l}\text { Inhälation } \\
\text { (RFD? }\end{array}$ & & & & & & & & \\
\hline INORGANIC CHEMICALS & & & & & & & & & & & & \\
\hline Arsenic & $5.8 \mathrm{E}+00$ & $3.0 E-4$ & $24 E-04$ & & 0.8 & 0.03 & 1.7E-06 & 7.1E-03 & $2.1 E-07$ & & $2.8 \varepsilon-06$ & $9.5 E-03$ \\
\hline SEMIVOLATILE ORGANIC CHEMICALS & & & & & & & & & & & & \\
\hline Bis(2-thylhexyl|phthalale & $2.4 E+02$ & $20 \mathrm{E}-2$ & $2.0 E-02$ & $22 \mathrm{E}-2$ & 1 & 0.10 & 2.3E-04 & $12 \mathrm{E}-02$ & $B .9 E-06$ & 4.0E-04 & $1.2 \mathrm{E}-04$ & 5. $9 E-03$ \\
\hline Motor oil" & $5.4 E+03$ & $6.0 E+0$ & $6.0 E+\infty$ & $6.0 E+0$ & 1 & 0.10 & $5.3 E-03$ & 8.8E-04 & $2.0 E-04$ & 3.3E-05 & 2.6E-03 & $44 E-04$ \\
\hline Waste pil" & $1.3 E+03$ & $6.0 E+0$ & $50 E+\infty 0$ & $6 D E+0$ & 1 & 0.10 & 1. $3 E-03$ & $2.1 \mathrm{E}-04$ & $4.8 \mathrm{E}-05$ & $B 0 E-06$ & $6.4 E-04$ & $1.1 \mathrm{E}-04$ \\
\hline PESTCIDES/PCEs & & & & & & & & & & & & \\
\hline Aroclor-1254 & 2 1E-01 & $20 \mathrm{E}-5$ & $2.0 \mathrm{E}-0.5$ & $20 \mathrm{E}-5$ & 1 & 0.06 & $1.2 \mathrm{E}-07$ & $6.2 E-03$ & $7.8 \mathrm{E}-09$ & $3.9 \mathrm{E}-04$ & $1.0 \mathrm{E}-07$ & $5.1 \mathrm{E}-03$ \\
\hline Total Noncancer Hazard & & & & & & & & $2.6 E-02$ & & 8.3E-04 & & $\overline{2}$ IE-02 \\
\hline
\end{tabular}

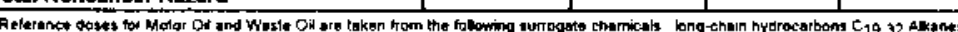




\section{Appendix B}

\section{Radiological Dose Assessment Area 6 Decontamination Pond Facility}




\section{Table of Contents}

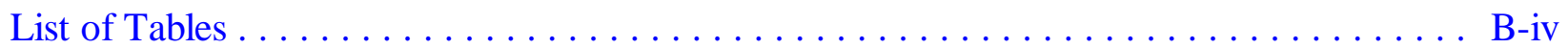

List of Acronyms and Abbreviations $\ldots \ldots \ldots \ldots \ldots \ldots \ldots \ldots \ldots \ldots \ldots \ldots$

B.1.0 Introduction $\ldots \ldots \ldots \ldots \ldots \ldots \ldots \ldots \ldots \ldots \ldots \ldots \ldots \ldots \ldots \ldots \ldots$

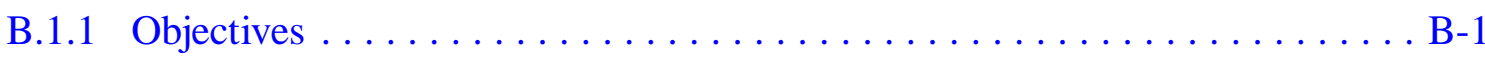

B.1.2 Regulatory Requirements ..................... B-2

B.2.0 Conceptual Site Model . . . . . . . . . . . . . . . . . . . . . . B-6

B.2.1 Radiological Sources and Potential COCs . . . . . . . . . . . . . . . B-6

B.2.2 Release Mechanisms . . . . . . . . . . . . . . . . . . . . . B-7

B.2.3 Exposure Pathways . . . . . . . . . . . . . . . . . .

B.2.4 Exposure Scenarios . . . . . . . . . . . . . . . . . . . B-9

B.3.0 Identification of the Chemicals of Potential Concern . . . . . . . . . . . . . B-14

B.3.1 Uncertainties in the Radiological Source Term . . . . . . . . . . . . . . . B-19

B.3.2 Summary of the COCs $\ldots \ldots \ldots \ldots \ldots \ldots \ldots \ldots \ldots \ldots \ldots \ldots \ldots$

B.4.0 Exposure Point Concentrations . . . . . . . . . . . . . . . . B-22

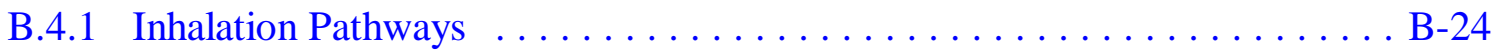

B.4.2 External Radiation Pathway $\ldots \ldots \ldots \ldots \ldots \ldots \ldots \ldots \ldots \ldots \ldots \ldots \ldots \ldots \ldots$

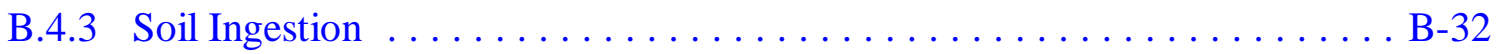

B.4.4 RESRAD Model for the DPF Contamination Zones . . . . . . . . . . . B-33

B.4.5 Time Dependance of the Exposure Point Concentration . . . . . . . . . B-33

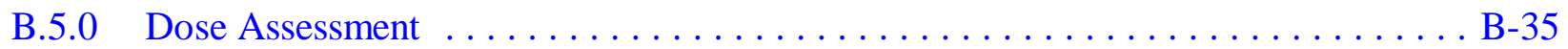

B.5.1 Dose Methodology for Inhalation $\ldots \ldots \ldots \ldots \ldots \ldots \ldots \ldots \ldots \ldots \ldots \ldots$

B.5.2 Dose from Ingestion of Radionuclides . . . . . . . . . . . . . . . . . . B-39

B.5.3 Dose from External Exposure $\ldots \ldots \ldots \ldots \ldots \ldots \ldots \ldots \ldots \ldots$. . . . . . . . . . . .

B.5.4 Doses from Radon Decay Products . . . . . . . . . . . . . . . . . B-43

B.5.5 Metabolic Process and Radioactive Decay . . . . . . . . . . . . . . . . B-43

B.6.0 Dose Assessment Summary . . . . . . . . . . . . . . . . . . . . B-51 


\section{Table of Contents (continued)}

B.7.0 Toxicity Assessment $\ldots \ldots \ldots \ldots \ldots \ldots \ldots \ldots \ldots \ldots \ldots \ldots \ldots \ldots$. . . . . . . . . . . .

B.8.0 Risk Characterization . . . . . . . . . . . . . . . . . . . . . . . B-58

B.9.0 Uncertainties in the Assessment $\ldots \ldots \ldots \ldots \ldots \ldots \ldots \ldots \ldots \ldots \ldots$. . . . . . . . . . . . .

B.10.0 References .................................. B-64

Attachment B.1 - RESRAD Inputs for the Dose Assessment . . . . . . . . . . . . . . . . B-68 


\section{List of Tables}

Number

B.2-1 Matrix of Potential Exposures Routes $\ldots \ldots \ldots \ldots \ldots \ldots \ldots \ldots \ldots \ldots$ B-10

B.2-2 Exposure Pathways at the Area 6 Decon Pond .................. B-13

B.3-1 Concentration of Radionuclides in Soil at Background Locations in Nevada ... . B-16

B.3-2 Determination of Radionuclide Contaminants of Potential Concern

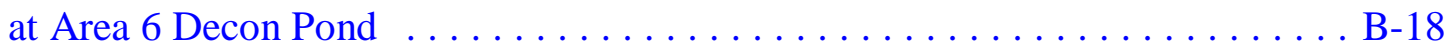

B.3-3 Mean Concentration of the Principal Radionuclides:

Contaminants of Concern at the Area 6 Decon Pond . . . . . . . . . . . . . . B-21

B.4-1 Parameter Values Used in RESRAD for Calculating Dose to a

Radiation Worker and an Industrial Worker on the Area 6 Decon Pond ....... B-25

B.5-1 Method for Calculating Dose from the Inhalation of Airborne Soil . . . . . . . B-37

B.5-2 Committed Effective Dose Equivalent Conversion Factors for Inhalation . . . . . B-38

B.5-3 Method for Calculating Dose from Soil Ingestion $\ldots \ldots \ldots \ldots \ldots \ldots \ldots$ B-40

B.5-4 Committed Effective Dose Equivalent Conversion Factors for Ingestion . . . . . . B-41

B.5-5 Method for Calculating External Dose from Radionuclides in the Ground . . . . . B-42

B.5-6 Effective Dose Equivalent Conversion Factors $\left(\mathrm{DCF}_{\mathrm{ji}}\right)$ for External Gamma from Contaminated Soil . . . . . . . . . . . . . . . . . . B-44 


\section{List of Tables (continued)}

B.5-7 Method for Calculating the Concentration of Radon in Outdoor

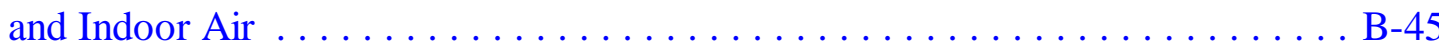

B.5-8 Radon Dosimetry . . . . . . . . . . . . . . . . . . . . . . . B-48

B.6-1 Dose Summary for the Hypothetical Radiation Worker at the Area 6 Decon Pond: No Action Alternatives . . . . . . . . . . . . . . . B-52

B.6-2 Dose Summary for the Hypothetical Radiation Worker at the Area 6 Decon Pond: Engineered Cap Alternatives . . . . . . . . . . . . . B-53

B.6-3 Dose Summary for the Hypothetical Industrial Worker at the Area 6 Decon Pond: No Action Alternatives . . . . . . . . . . . . . . . . . . . B-54

B.6-4 Dose Summary for the Hypothetical Industrial Worker at the Area 6 Decon Pond: Engineered Cap Alternatives $\ldots \ldots \ldots \ldots \ldots \ldots \ldots \ldots$ B-55

B.9-1 Uncertainties in the Dose and Risk Assessment . . . . . . . . . . . . . . B-61 


\section{List of Acronyms and Abbreviations}

\begin{tabular}{|c|c|}
\hline bgs & Below ground surface \\
\hline CFR & Code of Federal Regulations \\
\hline $\mathrm{cm}$ & Centimeter(s) \\
\hline $\mathrm{cm}^{3} / \mathrm{g}$ & Cubic centimeter(s) per gram \\
\hline $\mathrm{COC}$ & Contaminant(s) of concern \\
\hline DCF & Dose conversion factor \\
\hline DOE & U.S. Department of Energy \\
\hline $\mathrm{DPF}$ & Decontamination Pond Facility \\
\hline EDE & Effective dose equivalent \\
\hline EPA & U.S. Environmental Protection Agency \\
\hline $\mathrm{ft}$ & Foot (feet) \\
\hline $\mathrm{g} / \mathrm{cm}^{3}$ & Grams per cubic centimeters \\
\hline $\mathrm{g} / \mathrm{yr}$ & Grams per year \\
\hline GI & Gastrointestinal \\
\hline ICRP & International Council on Radiation Protection \\
\hline in. & $\operatorname{Inch}(\mathrm{es})$ \\
\hline $\mathrm{km}$ & Kilometer(s) \\
\hline $\mathrm{km}^{2}$ & Square kilometer(s) \\
\hline $\mathrm{m}$ & Meter(s) \\
\hline $\mathrm{m}^{2}$ & Square meter(s) \\
\hline MDA & Minimum Detectable Activity \\
\hline MDC & Minimum Detectable Concentration \\
\hline $\mathrm{m} / \mathrm{yr}$ & Meter(s) per year \\
\hline $\mathrm{m}^{3} / \mathrm{y}$ & Cubic meter(s) per year \\
\hline $\mathrm{mi}$ & Mile(s) \\
\hline $\mathrm{mi}^{2}$ & Square mile(s) \\
\hline mrem & Millirem(s) \\
\hline $\mathrm{mrem} / \mathrm{yr}$ & Millirem(s) per year \\
\hline NCRP & National Council on Radiation Protection and Measurement \\
\hline NRC & U.S. Nuclear Regulatory Commission \\
\hline NTS & Nevada Test Site \\
\hline $\mathrm{pCi} / \mathrm{g}$ & Picocurie(s) per gram \\
\hline $\mathrm{pCi} / \mathrm{L}$ & Picocurie(s) per liter \\
\hline
\end{tabular}




\section{List of Acronyms and Abbreviations (Continued)}

$\begin{array}{ll}\text { RME } & \text { Reasonable maximum exposure } \\ \text { TEDE } & \text { Total effective dose equivalent } \\ \text { TPH } & \text { Total petroleum hydrocarbon(s) } \\ \text { UCL } & \text { Upper confidence limit } \\ \text { WL } & \text { Working levels } \\ \text { WLM } & \text { Working level month } \\ \mu \mathrm{m} & \text { Micrometer } \\ \mu \mathrm{R} / \mathrm{h} & \text { Microroentgen per hour }\end{array}$




\section{B.1.0 Introduction}

This appendix contains the human health dose assessment based upon radionuclide contamination at the Nevada Test Site (NTS) Area 6 Decontamination Pond Facility (DPF). The DPF is characterized in terms of the source of its radiological contamination, the degree and extent of radiological contamination, and the potential receptors and subsequent dose and risk due to radiological contamination. The information provided in this appendix supports the decisionmaking process of closure options for the DPF.

\section{B.1.1 Objectives}

The objectives of this dose and risk assessment are as follows:

- Identify contaminant exposure routes and exposure pathways for present and hypothetical future dose receptors.

- Delineate the nature and extent of radiological soil contamination

- Quantify the dose and risk to the present and hypothetical future dose receptors.

Section 2.0 describes the conceptual site model, presents the exposure routes and pathways, and defines the present and hypothetical future dose receptors. Section 3.0 identifies the radiological contaminants of concern (COC) and their extent and concentration. Section 4.0 describes the COC concentration at the point of intake by the dose receptor and reviews the methodology used to compute the exposure concentration and intake. Section 5.0 describes the method for calculating dose for each exposure pathway. Section 6.0 presents the computed doses and compares them with the requirements in U.S. Department of Energy (DOE) Order 5400.5, Radiation Protection of the Public and the Environment (DOE, 1993). Section 7.0 describes the risk from radiological dose based upon human and animal studies. Section 8.0 presents the risk from the radiological contamination for current land uses and the hypothetical future land uses and compares them with federal standards. Section 9.0 discusses the uncertainties associated with the modeling of the site environment, dose assessment, toxicity, and risk coefficients. Section 10.0 lists the references cited in this appendix. 


\section{B.1.2 Regulatory Requirements}

The primary dose limits for members of the public from all DOE activities, including those involving remedial actions, are established in Chapters II and IV in DOE Order 5400.5 (DOE, 1993). The DOE has established three limits on the dose from residual radioactive material in soil: the basic dose limit, the guideline limit, and the authorized limit. The basic dose limit is 100 millirem per year (mrem/yr), and the other two limits are derived from this one. The guideline limit is the concentration of a radionuclide(s) in the soil that corresponds to the basic dose limit of $100 \mathrm{mrem} / \mathrm{yr}$. The authorized dose limit is required to be equal to or less than the guidance limit and is the concentration of the radionuclide(s) in the soil that is required for the corrective action to be considered complete.

The primary dose limit is expressed as a committed effective dose equivalent, a term developed by the International Commission on Radiological Protection (ICRP) for their risk-based system which requires the risk-weighted summation of doses to various tissues and organs of the body. The basic dose limit for members of the public due to their exposure to radiation sources as a consequence of all routine DOE activities must not cause, in a year, an effective dose equivalent greater than 100 millirem (mrem). This limit is used in establishing guideline concentrations of residual radioactive material in the soil, and it is an annual limit for members of public who are assumed to participate in worst-case exposure scenarios.

Radiological protection requirements and guidelines for cleanup of residual radionuclides in soil are included in Chapter IV of DOE Order 5400.5 (DOE, 1993). The basic dose limit is a prescribed standard used to derive limits for quantities that can be monitored and controlled. It is specified in terms of the effective dose equivalent (EDE). The basic dose limit is used for deriving guidelines for residual concentrations of radionuclides in soil. A guideline is a concentration of a radionuclide in soil that is acceptable for property use without restrictions due to residual radioactive material. DOE Order 5400.5, Chapter IV, states, "Residual concentrations of radioactive material in soil are defined as those in excess of background concentrations averaged over an area of 100 square meters $\left(\mathrm{m}^{2}\right)$ " (DOE, 1993). Guidelines for thorium and radium in soil have also been established in DOE Order 5400.5 (DOE, 1993); however, guidelines for residual concentrations for other radionuclides in soil have to be derived from the basic dose limit by means of an environmental pathway analysis using specific property data where available. Procedures for these derivations are given in A Manual for Implementing Residual Radioactive Material Guidelines (RESRAD) (Gilbert et al., 1989) in addition to guidance in applying RESRAD for computing guidance limits. The derivational procedures are implemented using the RESRAD computer code as indicated in Yu et al. (1993a). 
RESRAD incorporates the methodology for calculating residual radioactive guidelines first developed for DOE's Formerly Utilized Sites Remedial Action Program and its Surplus Facilities Management Program. RESRAD was developed to calculate radiation dose to on-site residents from residual radioactive material and determine soil guidelines according to the limits specified in DOE Order 5400.5 (DOE, 1993).

The authorized limits are defined in DOE Order 5400.5 as follows: "An authorized limit is a level of residual radioactive material that shall not be exceeded if the remedial action is to be considered completed and the property is to be released without restrictions on use due to residual radioactive material" (DOE, 1993). The authorized limits for a property are required to include:

- Limits for each radionuclide or group of radionuclides, as appropriate, associated with residual radioactive material in the soil

- Limits for each radionuclide or group of radionuclides, as appropriate, in air or water

- A limit on external gamma radiation resulting from the residual material.

Authorized limits for residual radioactive material are set equal to, or below, guideline values. A property may be released without restrictions if residual radioactive material does not exceed the authorized limits. The authorized limits are developed through the project offices in the field and are approved by the DOE Headquarters Program Office.

Remediation of the DPF requires that the following criteria in DOE Order 5400.5 (DOE, 1993) and Gilbert et al. (1989) be satisfied. These criteria are:

A. Guidelines for residual concentrations of radionuclides, other than radium or thorium, will be derived from the basic dose limits.

B. Environmental pathway analysis will be used in applying the basic dose limits.

C. Specific property data will be used where available.

D. Residual concentrations of radioactive material in soil are defined as those in excess of background concentrations averaged over an area of $100 \mathrm{~m}^{2}$.

E. The procedures in Gilbert et al. (1989) shall be used in deriving the guideline. 
F. Generic guideline limits are established for radium-226, radium,-228, thorium-230, and thorium-232. The generic guidelines are:

- 5 picocuries per gram ( $\mathrm{pCi} / \mathrm{g}$ ) above background, averaged over the first 15 centimeters $(\mathrm{cm})(0.5$ feet $[\mathrm{ft}])$ of soil below the ground surface

- $\quad 15 \mathrm{pCi} / \mathrm{g}$ above background, averaged over $15-\mathrm{cm}(0.5 \mathrm{ft})$ thick layers of soil more than $15 \mathrm{~cm}(0.5 \mathrm{ft})$ below the surface.

G. Generic guidelines are defined for airborne radon decay products in habitable structures on sites intended for release. The limit is a radon decay product concentration, including background, that does not exceed 0.2 working levels. No structures currently exist on the DPF. No habitable structures are likely to be on the DPF in the future. Nevertheless, for the sake of conservatism, the radon decay product concentration was calculated and compared to the 0.2 working level concentration limit.

H. The limit for external gamma radiation inside a building or habitable structure on a site to be released without restrictions shall not exceed the background level by more than 20 microroentgen per hour $(\mu \mathrm{R} / \mathrm{h})$ and shall comply with the basic dose limit when an "appropriate-use" scenario is considered. While the installation of a habitable building on the DPF is unlikely, this dose assessment includes a comparison between the calculated external dose rate and the $20 \mu \mathrm{R} / \mathrm{h}$ limit for buildings and habitable structures as a bounding estimate.

I. Generic surface contamination limits are provided in Figure IV-1 of DOE Order 5400.5 for buildings, structures and equipment; however, because no buildings, structures, or equipment exist on the DPF, these limits do not apply.

J. Residual concentrations of radionuclides in air and water are to be controlled to the required levels shown in paragraph II.1a of DOE Order 5400.5 (DOE, 1993) and as required by other applicable federal and/or State of Nevada laws. The Federal Clean Air Act (ES, 1988) requires that the dose from airborne radionuclides shall not exceed $10 \mathrm{mrem} / \mathrm{yr}$. Doses from inhalation are calculated and compared with this dose limit.

Small areas of surface soil that have elevated concentrations are known as "hot spots." The hot spot criteria in DOE Order Chapter IV, section 4a.(1) and Chapter 3, Section 3.3.2 of Gilbert et al. (1989) shall apply to the DPF closure. Procedures for calculating these hot-spot limits, which depend on the extent of the elevated local concentrations, are given also in Gilbert et al. (1989). The hot spot criterion states that the average concentration in any soil surface or below-surface area less than or equal to $25 \mathrm{~m}^{2}$ shall not exceed the guideline by a factor of $(100 / \mathrm{A})^{0.5}$ (where $\mathrm{A}$ is the area [in square meters] of the region of elevated concentrations). In addition, DOE Order 5400.5 states that a reasonable effort will be made to remove any 
radioactive source that exceeds the appropriate limit by a factor of thirty (DOE, 1993). Therefore, successful remediation of the DPF will require the following:

- The average soil concentration for any radionuclide in any one $100 \mathrm{~m}^{2}$ area must not exceed the authorized limit.

- The concentration of any radionuclide in any hot spot must not exceed the guidance in DOE Order 5400.5, Chapter IV, Section 4.a. (1) (DOE, 1993).

- Reasonable efforts will be made to remove any source of radionuclide that exceeds 30 times the appropriate limit for soil, regardless of the average concentration in the soil.

The latter two criteria will ensure that an area of elevated concentration does not result in an unacceptable increase in the potential dose to members of the public, even though the average concentration is less than the authorized limit. 


\section{B.2.0 Conceptual Site Model}

The conceptual model provides the basis for identifying and quantifying the potential dose and resultant risk to human health. The conceptual model facilitates consistent and comprehensive evaluation of dose by creating a framework for identifying the paths by which humans and the environment may be impacted by the radiological contaminants present at the DPF.

The elements necessary to develop the conceptual model include:

- Radiological sources and potential COCs

- Release mechanisms

- Exposure pathway

- Exposure scenarios

- Receptors

\section{B.2.1 Radiological Sources and Potential COCs}

The DPF is located near the western edge of the Yucca Lake bed in Yucca Flat which is a playa on the NTS that receives and collects surface runoff during heavy precipitation. The runoff collects at Yucca Lake, an ephemeral surface water body at the southern end of Yucca Flat. Until the surface water dissipates through evaporation or infiltration, it may be present in Yucca Lake for a few days or weeks. The site topography of the Yucca Lake bed consists of semiflat surfaces with small drainages.

The DPF, an unlined impoundment surrounded by an earthen berm, was used for the disposal of untreated liquid effluent discharged from the Decontamination Facility (Building 6-605) and the Industrial Laundry (Building 6-607) located nearby. The DPF is a square unit, approximately 60 meters $(\mathrm{m})(200 \mathrm{ft})$ long on each interior side and $1.5 \mathrm{~m}(5 \mathrm{ft})$ deep. Buildings 6-605 and 6-607 were used in the cleaning of radiologically contaminated equipment and clothing associated with testing activities at the NTS. The liquid effluent from these buildings is the sole source of the radiological contamination at the DPF. The COCs are the man-made radionuclides still existing in the soil at the DPF. Details on the concentration of the radionuclides in soil at the DPF and the COCs are found in Section B.3.0 of this appendix. 


\section{B.2.2 Release Mechanisms}

Release mechanisms are the processes that result in radionuclides and radiation being transported from the contaminated soil through an exposure path to the potential dose receptor. The release mechanisms for radionuclides in soil at the DPF include the following:

- Emission of photons from radionuclides in the soil

- Wind resuspension of contaminated soil particles from the surface soil into the air

- Emanation of radon gas from soil particles to the soil pores and into the air

- Activities by the hypothetical future workers that increase mass loading of soil in the air.

- Activities by the hypothetical future worker that may result in the inadvertent ingestion of soil.

- Radionuclides leached from the soil and transported to the aquifer

- Wind and water erosion of surface soil exposing radionuclides to the atmosphere

\section{B.2.3 Exposure Pathways}

Exposure pathways describe the release mechanisms, exposure point, and the exposure route where a potential dose receptor may receive an intake of a radionuclide. The potential exposure pathways that could be present at the DPF include the following:

- Direct exposure pathway: The dose receptor is on the DPF being exposed to photons emitted by radionuclides in the soil.

- The inhalation pathway: The dose receptor is located on the DPF inhaling air containing resuspended soil particles that are contaminated with radionuclides.

- The radon pathway: The dose receptor is located on the DPF inhaling the decay products from radon gas emitted from the soil surface.

- The soil ingestion pathway: The dose receptor inadvertently ingests soil, fugitive dust in the air, and dust from work surfaces that are contaminated with radionuclides.

Three potential exposure pathways have been rejected for analysis in this assessment: the groundwater pathway, the surface water pathway, and the food pathway. The groundwater pathway assumes that precipitation events will dissolve radionuclides in the soil and transport them through the vadose zone to groundwater where the contaminated water is utilized via a well. 
The water from the well could be used for drinking, industrial process water, feeding stock, and irrigating crops. The groundwater pathway is rejected from analysis in this assessment because:

- Depth to groundwater in the vicinity of the DPF varies from $460 \mathrm{~m}(1,500 \mathrm{ft})$ (DRI, 1988) to $500 \mathrm{~m}(1,600 \mathrm{ft})(\mathrm{DOE} / \mathrm{NV}, 1997)$.

- Computer stimulations demonstrate the probable advance of the wetting front beneath the DPF under historic conditions as well as worst-case scenarios for major storm events will not exceed $15 \mathrm{~m}$ (49 ft) after 100 years (DOE/NV, 1997).

- Most cationic species, such as radionuclides, are irreversibly sorbed by the zeolitic minerals in water and soil with a high $\mathrm{pH}$, which is typical of NTS playas (DOE/NV, 1997). Those radionuclides are expected to be irreversibly sorbed onto the native playa material at shallow depths (DOE/NV, 1997).

- Dissolved salts will not move as fast as the water fronts because water moves both in the vapor and water phase while dissolved salts move only in the liquid phase (DOE/NV, 1997).

The surface water pathway assumes that standing water such as lakes, ponds, rivers, and streams dissolves radionuclides from the soil. The water is then used for home, industry, and agricultural purposes. The hypothetical dose receptors are assumed to ingest the COCs dissolved in the water.

The surface water pathway is rejected because no permanent bodies of water exist at the DPF. Temporary shallow bodies of water exist on the Yucca Flat playa for a few days to weeks per year. In addition, the distribution coefficients for radionuclides in zeolites are very small resulting in extraordinarily low concentrations of the radionuclides in the surface water. Liquid in the DPF was monitored for average tritium, gross beta, and plutonium-239 concentrations as part of an NTS site-wide environmental monitoring program in 1985, 1987, 1988, and 1989 (DOE, 1996b). The concentrations were only 0.02 to 6 percent of community drinking water standards listed in Title 40 Code of Federal Regulations (CFR) Part 141.15 and Part 141.16 (CFR, 1996a). The resultant intake of radionuclides from the ingestion of surface water would be insignificant in comparison to other pathways.

The food pathway assumes that crops, animal stock such as dairy and beef cattle, and fresh water ponds for raising of fish occur on the contaminated site. The COCs are transported to the food via contaminated water, soil, air, and vegetation resulting in a dose to the individual consuming the food. 
The food pathway was rejected because it is extremely unlikely that agriculture would be practiced in such a harsh environment. The nearest wells are 1.6 kilometers $(\mathrm{km})(1 \mathrm{mile}[\mathrm{mi}])$ south of the DPF and the rainfall is scant, $15 \mathrm{~cm}$ (6 inches [in.]) per year (DOE, 1996a). The only locations in Nye county, where the NTS is located, where commercial agriculture is practiced is near natural springs and rivers.

A matrix of potential exposure routes for radionuclides in soils is shown in Table B.2-1.

\section{B.2.4 Exposure Scenarios}

An exposure scenario is a quantitative description of the interactions of the hypothetical dose receptor in an exposure pathway. An exposure scenario identifies those exposure pathways affecting the dose receptor and provides sufficient data for quantification of the radionuclide intake for that receptor. For example, if the exposure scenario assumes the dose receptor participates in the direct exposure pathway, the exposure scenario must quantify the following:

- The concentration and geometry of the radiological source term as a function of time

- The photon energy and emission rate as a function of time

- Conversion factors for quantifying absorbed dose as a function of photon energy flux

- Weighting factors for converting absorbed dose to effective dose equivalent

- The shielding effect of soil, soil cover, and soil cap as a function of time

- The shielding effects of a building while the dose receptor is inside

- The exposure time of the dose receptor on the DPF

At the present time, the DPF does not pose a significant health threat to either workers or the general public because it is under active institutional control. The DPF is located in an area restricted to members of the public; inadvertent human intrusion is deterred by the use of fences, warning signs, and security patrols. Future land use is defined in the Final Environmental Impact Statement (DOE/N, 1996b) and the Record of Decision: Environmental Impact Statement for the Nevada Test Site and Off-Site Locations in the State of Nevada (DOE, 1996). The leastrestrictive identified land use for Area 6 is a defense industrial zone. 
Table B.2-1

Matrix of Potential Exposures Routes

\begin{tabular}{|c|c|c|c|}
\hline $\begin{array}{l}\text { Exposure Medium/ } \\
\text { Exposure Route } \\
\end{array}$ & $\begin{array}{r}\text { Residential } \\
\text { Population } \\
\end{array}$ & $\begin{array}{c}\text { Commercial/Industrial } \\
\text { Population }\end{array}$ & $\begin{array}{c}\text { Recreational } \\
\text { Population } \\
\end{array}$ \\
\hline $\begin{array}{l}\text { Ground Water } \\
\text { Ingestion } \\
\text { Dermal/Contact }\end{array}$ & U & U & U \\
\hline $\begin{array}{l}\text { Surface Water } \\
\text { Ingestion } \\
\text { Dermal Contact }\end{array}$ & U & $\begin{array}{l}U \\
U\end{array}$ & U \\
\hline $\begin{array}{l}\text { Sediment } \\
\text { Incidental Ingestion } \\
\text { Dermal Contact }\end{array}$ & U & $\begin{array}{l}U \\
U\end{array}$ & $\begin{array}{l}U \\
U\end{array}$ \\
\hline $\begin{array}{l}\text { Ingestion of Dust } \\
\text { Indoors } \\
\text { Outdoors }\end{array}$ & $\begin{array}{l}U \\
U\end{array}$ & $\begin{array}{l}A \\
A\end{array}$ & 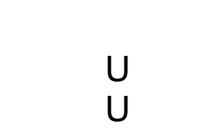 \\
\hline $\begin{array}{l}\text { Inhalation of Dust } \\
\text { Indoors } \\
\text { Outdoors }\end{array}$ & U & $\begin{array}{l}A \\
A\end{array}$ & U \\
\hline $\begin{array}{l}\text { Inhalation of Radon } \\
\text { Indoors } \\
\text { Outdoors }\end{array}$ & U & $\begin{array}{l}A \\
A\end{array}$ & $\begin{array}{l}U \\
U\end{array}$ \\
\hline $\begin{array}{l}\text { External Radiation } \\
\text { Indoors } \\
\text { Outdoors }\end{array}$ & U & $\begin{array}{l}A \\
A\end{array}$ & U \\
\hline $\begin{array}{l}\text { Food Ingestion } \\
\text { Fish and Shellfish } \\
\text { Meat and Game } \\
\text { Dairy } \\
\text { Eggs } \\
\text { Vegetables }\end{array}$ & $\begin{array}{l}U \\
U \\
U \\
U\end{array}$ & $\begin{array}{l}U \\
U \\
U \\
U \\
U\end{array}$ & $\begin{array}{l}U \\
U \\
U \\
U \\
U\end{array}$ \\
\hline
\end{tabular}

$\mathrm{U}=$ Unlikely potential exposure route

$A=$ Exposure to adults during occupational activities 
Radiological workers will be on the site in the future during closure activities. The remediation work is not expected to last longer than six weeks. In addition, the radiological workers involved in remediation at the DPF are required to wear personal protective equipment and respirators to protect them from exposure to radionuclides. Therefore, the radiological workers are not expected to receive any dose during closure significantly different from zero.

Two future land users identified for the DPF include a radiological worker and an industrial worker. The radiological worker scenario is assumed to be a likely land-use scenario. The worker is assumed to be on the DPF during and after each rain event to ascertain any effects from surface water erosion. Four rain events are assumed per year. The radiological worker is also assumed to be on the DPF an additional four times per year for surveillance purposes (e.g., performing radiological surveys, gathering filters from air monitors, or checking the integrity of the DPF closure). The radiological worker is assumed to be wearing no personnel protective equipment or a respirator. During the time on the DPF, the radiological worker is exposed to COCs in the soil. Details on the exposure parameters are found in Section B.4.0 of this appendix. Two closure alternatives are evaluated using the radiological worker exposure scenario: a no action alternative and an engineered cap. The no action alternative assumes that the DPF remains in its current state. The engineered cap alternative assumes that the $1.5-\mathrm{m}(5-\mathrm{ft})$ high berms are pushed into the DPF, $0.6 \mathrm{~m}$ (2 ft) of low-permeability material is placed on top of the DPF, and a cap of armoring material is placed on top of the low-permeability layer to protect against erosion.

The hypothetical future industrial worker land-use scenario is assumed to be an extremely unlikely event. The DPF has no available infrastructure such as paved roads, electricity, water wells, telephone lines, rail lines, buildings, or habitable structures. If a business were planning to operate in the vicinity of the DPF, there are buildings located $180 \mathrm{~m}(600 \mathrm{ft})$ away that could provide infrastructure support, keep the business out of the flood plain of the Yucca Flat playa, and ensure individuals would not be exposed to the COCs in the soil at the DPF. However, the industrial worker exposure scenario was analyzed to ensure the dose and risk assessment is conservative and bounding. The industrial worker exposure scenario has also been evaluated under the same two closure alternatives as the radiation worker.

The future industrial worker is assumed to be at the DPF 40 hours per week, 50 weeks per year, for thirty years. The industrial worker would be in a facility located on the DPF. Details on the exposure scenario parameter values are found in Section B.4.0 of this appendix. 
The rural resident scenario, a common exposure scenario, was rejected for this analysis as highly unlikely. The rural resident exposure scenario assumes that a family lives on the site, works offsite, and raises a portion of its food in a garden on the site. The rural resident exposure scenario was rejected for the following reasons:

- The DPF is located in a harsh and inhospitable area with periodic flooding, extreme temperatures, scant precipitation, and high winds.

- The DPF site is devoid of any infrastructure; there are no roads, electricity, wells, buildings, telephones, rail lines, stores, or habitable structures.

- The NTS is known by the public to be contaminated with long-lived radionuclides such as plutonium (DOE, 1996b)

- The average rural population density in Nye county on land not controlled by the federal government is less than 0.08 individuals per square kilometer $\left(\mathrm{km}^{2}\right)\left(0.20\right.$ per mi $\left.{ }^{2}\right)$ (DOE, 1996b). Assuming that population density, the probability of someone living on the DPF, if the NTS is unrestricted to the public, is about 1 in 3,300. If the present rural Nye county population were distributed throughout all of Nye County, the probability of someone living on the DPF would be less than 1 in 36,000 .

The exposure pathways associated with the exposure scenarios selected for the DPF are summarized in Table B.2-2. 
Table B.2-2

Exposure Pathways at the Area 6 Decon Pond

\begin{tabular}{|c|c|c|c|}
\hline $\begin{array}{c}\text { Potentially Exposed } \\
\text { Population }\end{array}$ & $\begin{array}{l}\text { Exposure Route } \\
\text { and Medium }\end{array}$ & $\begin{array}{l}\text { Pathway Selected } \\
\text { for Evaluation? }\end{array}$ & $\begin{array}{l}\text { Reason for Selection } \\
\text { or Exclusion }\end{array}$ \\
\hline$\frac{\text { Current Land Use }}{\text { Radiological worker }}$ & $\begin{array}{l}\text { External photon } \\
\text { exposure }\end{array}$ & Yes & $\begin{array}{l}\text { Photon-emitting } \\
\text { radionuclides present } \\
\text { in Decon Pond soil }\end{array}$ \\
\hline Radiological worker & Inhalation of dust & No & $\begin{array}{l}\text { Workers required to } \\
\text { wear respirators }\end{array}$ \\
\hline Radiological worker & $\begin{array}{l}\text { Inadvertent soil } \\
\text { ingestion }\end{array}$ & No & $\begin{array}{l}\text { Workers required to } \\
\text { wear personal } \\
\text { protective equipment } \\
\text { and respirators }\end{array}$ \\
\hline $\begin{array}{l}\text { Future Land Use } \\
\text { Radiological worker }\end{array}$ & $\begin{array}{l}\text { External exposure, } \\
\text { inhalation of dust and } \\
\text { radon, inadvertent soil } \\
\text { ingestion }\end{array}$ & Yes & $\begin{array}{l}\text { No radiological controls } \\
\text { assumed }\end{array}$ \\
\hline Industrial workers & $\begin{array}{l}\text { External exposure, } \\
\text { inhalation of dust and } \\
\text { radon, inadvertent soil } \\
\text { ingestion }\end{array}$ & Yes & $\begin{array}{l}\text { No radiological controls } \\
\text { assumed }\end{array}$ \\
\hline Residents & $\begin{array}{l}\text { Ingestion of } \\
\text { groundwater from local } \\
\text { wells, external } \\
\text { exposure, inhalation } \\
\text { and ingestion of dust }\end{array}$ & No & $\begin{array}{l}\text { Residents at the Decon } \\
\text { Pond are assumed to } \\
\text { be extraordinarily } \\
\text { unlikely. }\end{array}$ \\
\hline
\end{tabular}




\section{B.3.0 Identification of the Chemicals of Potential Concern}

Calculating the dose to an individual from radiological contamination in soil requires definition of a radiological source term. The radiological source term definition must include the concentration of each radionuclide contaminant in the soil, the area of the contaminated land, and the depth distribution of the contamination. The radiological source term is the region within which radionuclides are present in above-background concentrations and is the common source term and starting point for all exposure pathway analysis. The radiological source term is defined as the COCs for the radiological dose assessment of the DPF. The area and depth of the contamination in the radiological source term are not smooth and uniform.

For calculational purposes, an idealized geometry and radiological source term distribution are assumed. The idealized geometry is the simple shaped volume that represents the shape and size of the contaminated soil at the DPF. In RESRAD the DPF is modeled as a right, circular cylinder with the same surface area as the actual DPF. The height of the right, circular cylinder is equal to the thickness of the contaminated soil zone plus the thickness of a any cover and cap. The radionuclides are assumed to be uniformly distributed throughout the right, circular cylinder. The derivation of guideline concentrations is based upon this idealized contaminated region of cylindrical shape within which radionuclides are assumed to be uniformly distributed.

Background soil concentrations for radionuclides in soil were obtained from two sources. Concentrations for cesium-137, thorium-232, uranium-238, and plutonium-239/240 were obtained from Off-Site Radiation Exposure Review Project Phase II Soils Program (McArthur and Miller, 1989). Concentrations in soil samples from more than 100 communities in the vicinity of the NTS were collected and analyzed for these radionuclides. The data on surface soil taken from communities in Nevada were chosen as the background concentrations. The concentration of the thorium-232 and uranium-238 decay products were calculated by assuming they were in decay equilibrium. The concentrations of other man-made radionuclides in soil were obtained from the Environmental Monitoring Report for the Proposed Ward Valley California LLRW Facility (Atlan-Tech, 1992).

The monitoring reports are a compilation of the baseline and preoperational environmental monitoring of the proposed low-level radioactive waste site in Ward Valley, California. It was submitted as part of the licence application for the site. The report was peer-reviewed by the State of California, the Nuclear Regulatory Commission, and their independent contractors and 
includes data on the concentration in surface soils of fission products, activation products, source material, and special nuclear material at three locations around Needles, California. These locations are across the Colorado River from Nevada; their concentration of radionuclides in surface soils should not vary significantly from that of Nevada. The concentrations of radionuclides from the references are listed in Table B.3-1.

The process of selecting COCs began by determining conservative representative concentrations for the radionuclides detected in the soil at the DPF. This conservative concentration is referred to as the 95 percent upper confidence limit (UCL) (EPA, 1990). The EPA has published guidance on methods for defining the 95 percent UCL. The following rules were used to determine if a radionuclide would be included as a COC:

Rule 1:

Many radionuclides detected in the soil samples are members of the decay chains of natural background radionuclides such as thorium-232 and uranium-238. For this reason, if a radionuclide is present in DPF soil samples at naturally-occurring background concentrations, it would be eliminated from the quantitative dose assessment.

Rule 2:

Radionuclides that are infrequently detected may be artifacts in the data due to sampling, analytical, or other abnormalities. Radionuclides would be eliminated for use in the quantitative dose assessment if they were detected in 5 percent or less of the samples.

Rule 3:

A radionuclide would be eliminated from quantitative dose assessment if its concentration did not exceed five times the highest blank associated with that sample.

Rule 4:

If the concentration of a radionuclide in a sample does not exceed the minimum detectable concentration (MDC), and if the MDC is greater than the range for its concentration in soil at background locations, and if its concentration exceeded the MDC in at least 5 percent of the other soil samples, then the MDC is used for the quantitative dose assessment for that sample.

Rule 5:

If the concentration of a radionuclide in a sample is less than the MDC, and if the MDC is less than the concentration range for a radionuclide in soil from background locations, than the concentration for that sample is assumed to be zero.

Rule 6:

If the error in the measurement of the concentration of a radionuclide exceeds 50 percent of the mean, the sample is not used in the quantitative dose assessment. 
Rule 7:

If the concentration of tritium in soil water is less than the limit for public drinking water established in 40 CFR Part 141 (CFR, 1996), even if the tritium exceeds background, the tritium concentration will not be used in the quantitative dose assessment.

Rule 8:

The background concentration for each radionuclide was subtracted from the concentration found for that radionuclide in each DPF soil samples. The resulting concentration was evaluated for use in the quantitative dose assessment.

Table B.3-1

Concentration of Radionuclides in Soil at Background Locations in Nevada

\begin{tabular}{||l|c|l||}
\hline \multicolumn{1}{|c|}{ Radionuclide } & Concentration $(\mathrm{pCi} / \mathrm{g})$ & \multicolumn{1}{c||}{ Reference } \\
\hline \hline Cobalt-60 & $<0.02-0.1$ & Atlan-Tech, 1992 \\
\hline Strontium-90 & $<0.03-0.42$ & Atlan-Tech, 1992 \\
\hline Cesium-137 & $0.003-7.0$ & McArthur and Miller, 1989 \\
\hline Thallium-208 & $0.95-3.4$ & Atlan-Tech, 1992 \\
\hline Lead-210 & $0.21-3.21$ & McArthur and Miller, 1989 \\
\hline Lead-212 & $0.18-2.4$ & McArthur and Miller, 1989 \\
\hline Lead-214 & $0.21-3.21$ & McArthur and Miller, 1989 \\
\hline Radium-226 & $0.21-3.21$ & McArthur and Miller, 1989 \\
\hline Radium-228 & $0.18-2.4$ & McArthur and Miller, 1989 \\
\hline Actinium-228 & $0.18-2.4$ & McArthur and Miller, 1989 \\
\hline Thorium-234 & $0.21-3.21$ & McArthur and Miller, 1989 \\
\hline Plutonium-239/240 & $5.5 \times 10^{-7}-1.47 \times 10^{-4}$ & McArthur and Miller, 1989 \\
\hline
\end{tabular}

${ }^{a}$ Radionuclide is assumed to be in secular equilibrium with uranium-238 and, therefore, had the same concentration range as uranium-238.

${ }^{b}$ Radionuclide is assumed to be in secular equilibrium with thorium-232 and, therefore, had the same concentration range as thorium-232.

The results of the screening for radionuclide COCs in the DPF surface soil samples are listed in Table B.3-2. Fifteen radionuclides were identified as exceeding the laboratory minimum detection levels. Three radionuclides, thallium-208, lead-214, and radium-228, were eliminated from the quantitative dose assessment because the range of concentrations was not different from background. No radionuclides were excluded from the quantitative dose assessment for Rules 2 and 3. Though thorium-234 was detected only five percent of the time, the quality of the laboratory data was sufficient to include it in the quantitative dose assessment. Rule 7 resulted in all tritium sample results being eliminated from use in the quantitative dose assessment. The 
maximum tritium concentration measured in the soil water, 14 picocuries per liter $(\mathrm{pCi} / \mathrm{L})$, is less than 0.07 percent of the public drinking water standard of 20,000 $\mathrm{pCi} / \mathrm{L}$ (CFR, 1996a).

The concentration distribution of radionuclides in the DPF surface soil is not uniform. Nearly all of the contamination is in the top $0.3 \mathrm{~m}(1 \mathrm{ft})$, and virtually no contamination is found in samples taken from $1.2 \mathrm{~m}$ to $8 \mathrm{~m}$ (4 to $27 \mathrm{ft}$ ). Therefore, the soil at the DPF was partitioned into eight zones. These zones are defined in the following way:

$$
\begin{array}{ll}
0 \text { to } 15 \mathrm{~cm}(0 \text { to } 0.5 \mathrm{ft}) & 61 \text { to } 91 \mathrm{~cm}(2 \text { to } 3 \mathrm{ft}) \\
15 \text { to } 31 \mathrm{~cm}(0.5 \text { to } 1 \mathrm{ft}) & 91 \text { to } 1.2 \mathrm{~m}(3 \text { to } 4 \mathrm{ft}) \\
31 \text { to } 46 \mathrm{~cm}(0 \text { to } 1.5 \mathrm{ft}) & 1.2 \text { to } 2.1 \mathrm{~m}(4 \text { to } 7 \mathrm{ft}) \\
46 \text { to } 61 \mathrm{~cm}(1.5 \text { to } 2 \mathrm{ft}) & \text { greater than } 2.1 \mathrm{~m}(7 \mathrm{ft})
\end{array}
$$

Another rational for dividing the soil into approximately $0.15 \mathrm{~m}(0.5 \mathrm{ft})$ deep sections is because radium-226 is a possible COC. The DOE Order 5400.5 limit on the allowed concentration of radium-226 in soil is based, by reference, on 40 CFR Part 192 (DOE, 1993). Title 40 CFR Part 192 defines the limits for radium-226 in soil in $0.15 \mathrm{~m}(0.5 \mathrm{ft})$ layers (CFR, 1996b).

The U.S. Environmental Protection Agency (EPA) recommends that the 95 percent UCL be used in estimating the risk from a contaminant in soil (EPA, 1990). The net concentration, the measured concentration minus the background, should be used in calculating the 95 percent UCL. The EPA provides guidance in selecting the 95 percent UCL when the concentrations of the COCs are normally or log-normally distributed. The net concentration of the radionuclides in the DPF soil was calculated by subtracting the background concentrations listed in Table B.3-1 from the concentrations measured in the soil at the DPF. The net contamination at the DPF is neither normally nor log-normally distributed. The 95 percent UCL concentration of each COC was calculated in the following manner:

- The concentration of a COC in soil representing the 95 percent UCL is defined as the arithmetic mean of the net concentration plus 1.96 times the standard deviation of the arithmetic mean. 
Table B.3-2

Determination of Radionuclide Contaminants of Potential Concern at Area 6 Decon Pond

\begin{tabular}{|c|c|c|c|c|c|c|}
\hline Radionuclide & $\begin{array}{c}\text { Frequency of } \\
\text { Detection } \\
\text { (\# detects / \# samples) }\end{array}$ & $\begin{array}{c}\text { Sample } \\
\text { Distribution } \\
(\mathrm{pCi} / \mathrm{g}) \\
\end{array}$ & $\begin{array}{l}\text { Background } \\
\qquad(\mathrm{pCi} / \mathrm{g})\end{array}$ & $\begin{array}{l}\text { Range of MDA } \\
\qquad(\mathrm{pCi} / \mathrm{g})\end{array}$ & $\begin{array}{l}\text { Distribution } \\
\text { Type }\end{array}$ & $\begin{array}{c}\text { Retained or Excluded } \\
\text { as COC }\end{array}$ \\
\hline Cobalt-60 & 27 / 122 & ND - 197 & $<0.02-0.1$ & $0.3-1.6$ & Log normal & Retained \\
\hline Strontium-90 & 42 / 62 & $0.21-22$ & $<0.03-0.42$ & $0.09-0.25$ & Log normal & Retained \\
\hline Cesium-137 & $40 / 122$ & ND - 182 & $0.003-7.0$ & $0.3-14.1$ & Log normal & Retained \\
\hline Thallium-208 & $23 / 41$ & ND - 1.2 & $0.95-3.4$ & $0.29-0.6$ & Normal & $\begin{array}{l}\text { Excluded - below } \\
\text { background }\end{array}$ \\
\hline Lead-210 & $5 / 41$ & ND - 6.96 & $0.21-3.21$ & $1.4-4.02$ & Normal & Retained \\
\hline Lead-212 & 45 / 45 & $1.24-3.17$ & $0.18-2.4$ & $0.3-0.82$ & Normal & Retained \\
\hline Lead-214 & 39 / 39 & $0.8-2.12$ & $0.21-3.21$ & $0.4-0.87$ & Normal & $\begin{array}{l}\text { Excluded - below } \\
\text { background }\end{array}$ \\
\hline Radium-226 & 12 / 41 & $5.89-8.08$ & $0.21-3.21$ & $3.97-21.4$ & Normal & Retained \\
\hline Radium-228 & $2 / 41$ & $1.98-2.36$ & $0.18-2.4$ & $0.49-2.4$ & Normal & $\begin{array}{l}\text { Excluded - below } \\
\text { background }\end{array}$ \\
\hline Actinium-228 & $4 / 41$ & $1.27-2.80$ & $0.18-2.4$ & $1.26-2.49$ & Normal & Retained \\
\hline Thorium-234 & $2 / 41$ & $3.14-5.06$ & $0.21-3.21$ & $2.36-2.54$ & Normal & Retained \\
\hline Plutonium-238 & $15 / 103$ & ND - 1.87 & NA & $0.022-0.16$ & Normal & Retained \\
\hline Plutonium-239/240 & $16 / 103$ & ND - 12.3 & $5.5 \times 10^{-7}-1.47 \times 10^{-4}$ & $0.023-0.3$ & Normal & Retained \\
\hline Americium-241 & $7 / 122$ & ND - 9.04 & NA & 1.54 & Normal & Retained \\
\hline
\end{tabular}

MDA = Minimum detectable activity

$\mathrm{COC}=$ Contaminant of concern

NA $=$ Not available, Pu-238 and Am-241 not detected in soil from background locations 
- For plutonium-238, about 80 percent of the samples were either less than or slightly greater than the MDC. The remaining samples were approximately 20 times the MDC. Because the distribution was skewed, the MDC was assigned to the non-positive samples, and the calculated arithmetic mean of the distribution was used in the quantitative dose assessment.

\section{B.3.1 Uncertainties in the Radiological Source Term}

The most significant uncertainty in the radiological source term is the concentration of the radium-226. Why radium-226 is present at concentrations greater than background is not readily apparent. As stated in Section 2.0, the radiological source term in the DPF is due to the liquid effluent from Buildings 6-605 and 6-607. The radionuclides were created during nuclear detonations. Radium-226 is not created during nuclear detonations; it is part of the uranium-238 decay chain. Radium-226 concentration builds up slowly over millions of years from the decay of the uranium-238.

The mean concentration of radium-226 in soil at the DPF was approximately 2 to 2.5 times that found in background locations. However, the radium-226 concentrations were measured using gamma spectroscopy. The average error in the radium-226 concentration was 31 percent, which is relatively large. At the 95 percent confidence level, the concentration of radium-226 measured in the soil at the DPF does not exceed the 95 percent confidence level of the background concentration.

Additional evidence to support the conclusion that the radium-226 is from natural sources is based upon the concentration ratios of the radium-226 and the other radionuclides in the uranium238 decay chain. The special nuclear material used in nuclear detonations is separated from the feed material with very strict controls to ensure a minimum of contamination. Any radium-226 present in the special nuclear material would be due to the decay of uranium-238. None of the special nuclear material in a nuclear device is more than 50 years old. Therefore, the activity ratio of the radionuclides in the uranium-238 decay chain can be calculated based upon 50 years of radioactive decay.

After 50 years of decay, the activity ratio of the thorium-234 to radium-226 should be approximately 45 billion to one. That is, the concentration of the thorium-234 in soil should be 45 billion times higher than the radium-226. However, the activity ratio of the thorium-234 and the radium-226 is less than one. The activity of the radium-226 is slightly higher than the thorium-234; therefore, the radium-226 could not have possibly come from the special nuclear material in a nuclear device. Despite the low thorium-234 to radium-226 concentration ratio; 
however, the radium-226 was not eliminated from the list of COCs. The laboratory data met all data qualification requirements and the concentration of the radium-226 exceeded background.

\section{B.3.2 Summary of the COCs}

The concentration of the radionuclides used in the quantitative dose assessment is listed in Table B.3-3. A partition between two groups of radionuclides is obvious. The fission and activation products (cobalt-60, strontium-90, and cesium-137) are found primarily in the top $0.3 \mathrm{~m}(1 \mathrm{ft})$ of soil. The decay products of natural uranium-238 and thorium-232 are found at

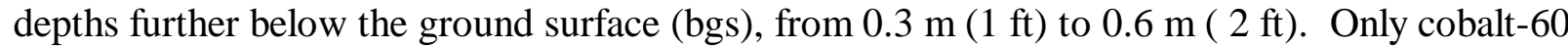

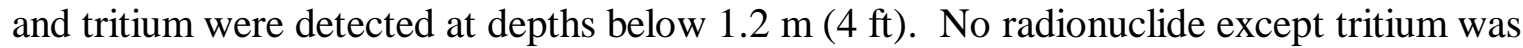
detected more than $2 \mathrm{~m}$ (7 ft) bgs. This radionuclide source term, both the concentration and the depth distribution, defines the COCs. 
Table B.3-3

Mean Concentration of the Principal Radionuclides:

Contaminants of Concern at the Area 6 Decon Pond $(\mathrm{pCi} / \mathrm{g})$

\begin{tabular}{|c|c|c|c|c|c|c|c|c|}
\hline Isotope & $\begin{array}{c}\text { Zone } 1 \\
0-0.15 \mathrm{~m} \\
(0-0.5 \mathrm{ft}) \\
\text { bgs } \\
\end{array}$ & $\begin{array}{c}\text { Zone } 2 \\
0.15-.3 \mathrm{~m} \\
(0.5-1 \mathrm{ft}) \\
\text { bgs }\end{array}$ & $\begin{array}{c}\text { Zone } 3 \\
0.3-.46 \mathrm{~m} \\
(1-1.5 \mathrm{ft}) \\
\text { bgs }\end{array}$ & $\begin{array}{c}\text { Zone } 4 \\
0.46-.6 \mathrm{~m} \\
(1.5-2 \mathrm{ft}) \\
\text { bgs }\end{array}$ & $\begin{array}{c}\text { Zone } 5 \\
0.6-.91 \mathrm{~m} \\
(2-3 \mathrm{ft}) \\
\text { bgs } \\
\end{array}$ & $\begin{array}{c}\text { Zone } 6 \\
0.91-1.28 \mathrm{~m} \\
(3-4 \mathrm{ft}) \\
\text { bgs }\end{array}$ & $\begin{array}{c}\text { Zone } 7 \\
1.2-2.1 \mathrm{~m} \\
(4-7 \mathrm{ft}) \\
\text { bgs } \\
\end{array}$ & $\begin{array}{c}>2.1 \mathrm{~m} \\
(>7 \mathrm{ft}) \\
\text { bgs }\end{array}$ \\
\hline Cobalt-60 & 61.13 & 34.0 & 0.3 & 0.3 & 0.41 & 4.58 & 0.34 & 0.0 \\
\hline Strontium-90 & 9.64 & 4.82 & 0.51 & 1.61 & 0.07 & 0.0 & 0.0 & 0.0 \\
\hline Cesium-137 & 28.29 & 26.7 & 0.0 & 0.0 & 0.0 & 2.27 & 0.0 & 0.0 \\
\hline Lead-210 & 0.0 & 0.0 & 2.49 & 1.29 & 0.0 & 0.0 & 0.0 & 0.0 \\
\hline Lead-212 & 0.0 & 1.17 & 0.0 & 2.27 & 0.0 & 0.0 & 0.0 & 0.0 \\
\hline Radium-226 & 0.0 & 5.86 & 6.00 & 4.81 & 1.50 & 1.50 & 1.50 & 0.0 \\
\hline Actinium-228 & 0.0 & 1.08 & 1.40 & 0.0 & 0.0 & 0.0 & 0.0 & 0.0 \\
\hline Thorium-234 & 0.0 & 0.0 & 2.03 & 1.54 & 0.0 & 0.0 & 0.0 & 0.0 \\
\hline Americium-241 & 4.79 & 3.79 & 0.85 & 0.85 & 0.85 & 0.85 & 0.85 & 0.85 \\
\hline Plutonium-238 & 0.47 & 0.39 & 0.11 & 0.18 & 0.19 & 0.08 & 0.08 & 0.08 \\
\hline Plutonium-239 & 4.45 & 4.57 & 0.08 & 0.08 & 0.08 & 0.08 & 0.08 & 0.08 \\
\hline Plutonium-240 & 4.45 & 4.57 & 0.08 & 0.08 & 0.08 & 0.08 & 0.08 & 0.08 \\
\hline
\end{tabular}

The minimum detectable concentration for americuim-241 is $0.85 \mathrm{pCi} / \mathrm{g}$, and was used for Zones 3-8 because background concentration was less than the MDA

The minimum detectable concentration for plutonium -238 is $0.08 \mathrm{pCi} / \mathrm{g}$, and was used for Zones $6-8$ because background concentration was less than the MDA.

The minimum detectable concentration for plutonium-239/240 is $0.08 \mathrm{pCi} / \mathrm{g}$, which exceeds background, and was used for Zones 3-8 because background concentration was less than the MDA.

Concentration 0.0 was assigned to results less than background.

bgs $=$ Below ground surface 


\section{B.4.0 Exposure Point Concentrations}

This section describes the calculations of the COC concentrations at the point of intake by the dose receptor. For example, the concentration of a COC in air when inhaled by the dose receptor is dependent on several parameters:

- The concentration of a COC in soil being resuspended into the air

- The mass loading of the contaminated soil in air

- The mixing of the contaminated air with clean air from off the DPF

The soil that may be resuspended into the air is the surface soil located in the top two millimeters. The concentration of a COC at any given time in the surface soil is dependent on the following factors:

- Initial concentration of the radionuclide in soil

- Time period from the initial time to when the contaminated air is being inhaled

- Radioactive decay rate

- Ingrowth in concentration due to the decay of the parent

- The vertical distribution of the COC in the soil

- Concentration of the radionuclide in the soil above

- Rate of removal from the soil due to leaching

- Rate of removal by other dynamic processes, such as wind erosion, surface water erosion, surface water leaching, uptake by plants, and ingestion by livestock.

Not all of the processes listed above occur at the DPF. Removal of radionuclides from the soil by plant uptake and ingestion by livestock or other grazing animals do not occur. Surface water leaching and erosion may occur and would result in a reduction of the radiological source term at the DPF. For the sake of conservatism, surface water leaching and erosion are not considered in this assessment.

Calculating the exposure point concentrations is a complex process. The computer code RESRAD was used in this assessment to calculate the exposure point concentrations. The exposure point concentrations calculated by RESRAD are based upon a pathway analysis known 
as the concentration factor method (U.S. Nuclear Regulatory Commission [NRC] 1977; ICRP, 1979-1982; Till and Meyer, 1983; and National Council on Radiation Protection and Measurements [NCRP], 1984). With this method, the relationship between radionuclide concentration in soil and the dose to a hypothetical dose receptor is expressed as a sum of the products of "pathway factors." Pathway factors correspond to pathway segments connecting compartments in models of the environment between which radionuclides can be transported or radiation transmitted.

Most pathway factors are assumed to be steady-state ratios of concentrations in adjoining compartments. The pathway factors include use and occupancy factors that affect exposure. Each term in the sum corresponds to a pathway of connected segments. A pathway product or pathway factor may be added, deleted, or replaced by the code user without affecting the other pathways or pathway factors. This structuring facilitates the use of alternative models for different conditions or transport processes and the incorporation of additional pathways. In this way, RESRAD input values can be modified or tailored to model a given situation by merely adding or replacing factors or terms in the pathway sum.

RESRAD calculates the exposure point concentration to a hypothetical receptor by performing the three following types of analysis:

- Source analysis

- Scenario analysis

- Environmental transport analysis

- Exposure/dose analysis.

Source analysis addresses the derivation of the source terms that determine the rate of release of radioactivity into the environment. The release rate of the surface soil into the environment is constant under steady-state conditions. However, the concentration of the radionuclides in the soil changes with time. The rate of change in the concentration of the radionuclides in the soil is determined by the geometry of the contaminated zone, the initial concentration of the radionuclides in the soil, the radioactive ingrowth and decay, and the leaching of radionuclides from the soil. 
Environmental transport analysis addresses the problems of identifying environmental pathways by which radionuclides can migrate from the source to a human exposure location and determining the migration rate along these pathways.

Scenario analysis is performed by defining the potential land uses for the DPF and associated human activities. RESRAD addresses the influence of the patterns of human activity on the rate of radionuclide releases into the environment and the severity and duration of human exposure at a given location.

The quantification of the relationship between the concentration of a radionuclide in the DPF soil to its concentration at the exposure point is performed by RESRAD using environmental transport analysis. Environmental transfer factors are the grams/year (g/yr) of soil taken into the body and are calculated as a function of time for each radionuclide in the soil.

The following sections describe the exposure pathway analysis for the DPF human health radiological dose assessment.

\section{B.4.1 Inhalation Pathways}

Inhalation exposure results primarily from inhalation of radon gas decay products and contaminated soil and dust resuspended in the air. An inhalation pathway consists of two segments: (1) an airborne exposure segment linking the source (contaminated soil in a zone) with the airborne radionuclides at an exposure location, and (2) an inhalation segment linking the airborne radionuclides with the exposed individual. The inhalation segment is characterized by an occupancy factor (an equivalent fraction of time during which the dose receptor inhales contaminated air) and a factor for the inhalation rate. Numerical values for the occupancy and inhalation factors are listed in Table B.4-1. The airborne exposure pathway segment, the critical segment, is characterized by the air/soil concentration ratio which is defined as the ratio of the airborne concentration of a radionuclide at the dose receptor's location to the concentration in the soil. The air/soil concentration ratio for contaminated soil and dust in air depends on the complex process by which soil particles become airborne by resuspension and are transported to an exposure location. An annual average mass loading based upon measurements in rural locations (Gilbert et al., 1989) was used in this assessment. For the radon pathway, the air/soil concentration ratio is calculated by solving radon diffusion equations for the soil and for the atmosphere. 
Table B.4-1

Parameter Values Used in RESRAD for Calculating Dose to a Radiation Worker and an Industrial Worker on the Area 6 Decon Pond ${ }^{a}$ (Page 1 of 7 )

\begin{tabular}{|c|c|c|c|}
\hline Parameter & Unit & $\begin{array}{c}\text { Scenario } \\
\text { Value }\end{array}$ & Notes \\
\hline Dose Limit & $\mathrm{mrem} / \mathrm{yr}$ & 100 & DOE, 1993 \\
\hline Area of contaminated zone & $\mathrm{m}^{2}$ & $3.72 E+3$ & DOE/NV, 1997 \\
\hline $\begin{array}{l}\text { Thickness of contaminated zone } \\
\text { Zone } 1 \\
\text { Zone } 2 \\
\text { Zone } 3 \\
\text { Zone } 4 \\
\text { Zone } 5 \\
\text { Zone } 6 \\
\text { Zone } 7\end{array}$ & $\mathrm{~m}$ & $\begin{array}{l}0.0-0.15 \\
0.15-0.3 \\
0.3-0.46 \\
0.46-0.61 \\
0.61-0.91 \\
0.91-1.29 \\
>1.29\end{array}$ & NA \\
\hline Length parallel to aquifer flow & $\mathrm{m}$ & 86 & DOE/NV, 1997 \\
\hline Time since placement of material & years & 0 & User assumption \\
\hline $\begin{array}{l}\text { Times for calculation } \\
1,10,20,30,40,50,60,70,100,150,175 \\
350,400,450,475,500,600,700,800 \\
1000,1100,1200,1250,1300,1350,1400 \\
1500,1600,1800,2000\end{array}$ & years & NA & User assumption \\
\hline $\begin{array}{l}\text { Mean concentration of initial principal } \\
\text { radionuclides in Zone } 1,0-0.15 \mathrm{~m}(0-0.5 \\
\mathrm{ft}) \text { below ground surface: } \\
\text { Cobalt-60 } \\
\text { Cesium-137 + D } \\
\text { Strontium-90 + D } \\
\text { Americium-241 } \\
\text { Plutonium-238 } \\
\text { Plutonium-239 } \\
\text { Plutonium-240 }\end{array}$ & $\mathrm{pCi} / \mathrm{g}$ & $\begin{array}{r}61.13 \\
28.29 \\
9.64 \\
4.79 \\
0.47 \\
4.45 \\
4.45\end{array}$ & DOE/NV, 1997 \\
\hline
\end{tabular}


Table B.4-1

Parameter Values Used in RESRAD for Calculating Dose to a Radiation Worker and an Industrial Worker on the Area 6 Decon Pond ${ }^{a}$

(Page 2 of 7 )

\begin{tabular}{|c|c|c|c|}
\hline Parameter & Unit & $\begin{array}{c}\text { Scenario } \\
\text { Value }\end{array}$ & Notes \\
\hline $\begin{array}{l}\text { Concentration of initial principal } \\
\text { radionuclides in Zone 2, } 0.15-0.3 \mathrm{~m}(0.5 \text { - } \\
\text { 1ft) below ground surface: } \\
\text { Cobalt-60 } \\
\text { Cesium-137 + D } \\
\text { Strontium-90 + D } \\
\text { Lead-212 } \\
\text { Radium-226 + D } \\
\text { Actinium-228 } \\
\text { Americium-241 } \\
\text { Plutonium-238 } \\
\text { Plutonium-239 } \\
\text { Plutonium-240 }\end{array}$ & $\mathrm{pCi} / \mathrm{g}$ & $\begin{array}{c}34 \\
26.7 \\
4.82 \\
1.17 \\
5.86 \\
1.08 \\
3.79 \\
0.39 \\
4.57 \\
4.57\end{array}$ & DOE/NV, 1997 \\
\hline $\begin{array}{l}\text { Concentration of initial principal } \\
\text { radionuclides in Zone } 3,0.3-0.46 \mathrm{~m} \\
\text { (1-1.5 ft) below ground surface: } \\
\text { Cobalt- } 60 \\
\text { Strontium-90 + D } \\
\text { Lead-210 } \\
\text { Radium-226 } \\
\text { Actinium-228 } \\
\text { Thorium-234 } \\
\text { Americium-241 } \\
\text { Plutonium-238 } \\
\text { Plutonium-239 } \\
\text { Plutonium-240 }\end{array}$ & $\mathrm{pCi} / \mathrm{g}$ & $\begin{array}{c}0.3 \\
0.51 \\
2.49 \\
6.00 \\
1.4 \\
2.03 \\
0.85 \\
0.11 \\
0.08 \\
0.08\end{array}$ & DOE/NV, 1997 \\
\hline $\begin{array}{l}\text { Concentration of initial principal } \\
\text { radionuclides in Zone } 4,0.46-0.61 \mathrm{~m} \\
\text { (1.5 - } 2 \mathrm{ft}) \text { below ground surface: } \\
\text { Cobalt- } 60 \\
\text { Strontium- } 90+\mathrm{D} \\
\text { Lead-210 } \\
\text { Lead-212 } \\
\text { Radium-226 } \\
\text { Thorium-234 } \\
\text { Americium-241 } \\
\text { Plutonium-238 } \\
\text { Plutonium-239 } \\
\text { Plutonium-240 }\end{array}$ & $\mathrm{pCi} / \mathrm{g}$ & $\begin{array}{c}0.3 \\
1.61 \\
1.29 \\
2.27 \\
4.81 \\
1.54 \\
0.85 \\
0.19 \\
0.08 \\
0.08\end{array}$ & DOE/NV, 1997 \\
\hline
\end{tabular}


Table B.4-1

Parameter Values Used in RESRAD for Calculating Dose to a Radiation Worker and an Industrial Worker on the Area 6 Decon Pond ${ }^{a}$ (Page 3 of 7 )

\begin{tabular}{|c|c|c|c|}
\hline Parameter & Unit & $\begin{array}{l}\text { Scenario } \\
\text { Value }\end{array}$ & Notes \\
\hline $\begin{array}{l}\text { Concentration of initial principal } \\
\text { radionuclides in Zone 5, } 0.61-0.91 \mathrm{~m} \\
\text { (2 - } 3 \mathrm{ft} \text { ) below ground surface: } \\
\text { Cobalt-60 } \\
\text { Strontium-90 + D } \\
\text { Radium-226 } \\
\text { Americium-241 } \\
\text { Plutonium-238 } \\
\text { Plutonium-239 } \\
\text { Plutonium-240 }\end{array}$ & $\mathrm{pCi} / \mathrm{g}$ & $\begin{array}{l}0.41 \\
0.07 \\
1.50 \\
0.85 \\
0.19 \\
0.08 \\
0.08\end{array}$ & DOE/NV, 1997 \\
\hline $\begin{array}{l}\text { Concentration of initial principal } \\
\text { radionuclides in Zone } 6,0.91-1.291 \mathrm{~m} \\
(2-3 \mathrm{ft}) \text { below ground surface: } \\
\text { Cobalt-60 } \\
\text { Cesium-137 + D } \\
\text { Americium-241 } \\
\text { Plutonium-238 } \\
\text { Plutonium-239 } \\
\text { Plutonium-240 }\end{array}$ & $\mathrm{pCi} / \mathrm{g}$ & $\begin{array}{l}4.58 \\
2.27 \\
0.85 \\
0.08 \\
0.08 \\
0.08\end{array}$ & DOE/NV, 1997 \\
\hline $\begin{array}{l}\text { Concentration of initial principal } \\
\text { radionuclides in Zone } 7,1.291-2.13 \mathrm{~m} \\
\text { ( } 4 \text { - } 7 \mathrm{ft} \text { ) below ground surface: } \\
\text { Cobalt-60 } \\
\text { Americium-241 } \\
\text { Plutonium-238 } \\
\text { Plutonium-239 } \\
\text { Plutonium-240 }\end{array}$ & $\mathrm{pCi} / \mathrm{g}$ & $\begin{array}{l}0.34 \\
0.85 \\
0.08 \\
0.08 \\
0.08\end{array}$ & DOE/NV, 1997 \\
\hline $\begin{array}{l}\text { Concentration of radionuclides in } \\
\text { groundwater }\end{array}$ & $\mathrm{pCi} / \mathrm{L}$ & not used & $\begin{array}{l}\text { RESRAD } D^{b} \text { calculates } \\
\text { from input data }\end{array}$ \\
\hline
\end{tabular}




\begin{abstract}
Table B.4-1
Parameter Values Used in RESRAD for Calculating Dose to a Radiation Worker and an Industrial Worker on the Area 6 Decon Pond ${ }^{a}$
\end{abstract} (Page 4 of 7 )

\begin{tabular}{|c|c|c|c|}
\hline Parameter & Unit & $\begin{array}{l}\text { Scenario } \\
\text { Value }\end{array}$ & Notes \\
\hline $\begin{array}{l}\text { Cover depth } \\
\text { No action alternative } \\
\text { Zone } 1 \\
\text { Zone } 2 \\
\text { Zone } 3 \\
\text { Zone } 4 \\
\text { Zone } 5 \\
\text { Zone } 6 \\
\text { Zone } 7 \\
\text { Engineered cap alternative } \\
\text { Zone } 1 \\
\text { Zone } 2 \\
\text { Zone } 3 \\
\text { Zone } 4 \\
\text { Zone } 5 \\
\text { Zone } 6 \\
\text { Zone } 7\end{array}$ & $\mathrm{~m}$ & $\begin{array}{c}0 \\
0.1524 \\
0.3048 \\
0.4572 \\
0.6096 \\
0.9144 \\
1.2192 \\
\\
0.762 \\
0.9144 \\
1.0668 \\
1.2192 \\
1.3716 \\
1.6764 \\
1.9872\end{array}$ & User assumption \\
\hline $\begin{array}{l}\text { Density of contaminated, saturated, and } \\
\text { unsaturated zone }\end{array}$ & $\mathrm{g} / \mathrm{cm}^{3}$ & 1.5 & RESRAD default \\
\hline $\begin{array}{l}\text { Density of cover material for no action } \\
\text { alternative }\end{array}$ & $\mathrm{g} / \mathrm{cm}^{3}$ & 1.5 & RESRAD default \\
\hline $\begin{array}{l}\text { Density of cover material for the Engineered } \\
\text { Cap scenario } \\
\text { Zone } 1 \\
\text { Zone } 2 \\
\text { Zone } 3 \\
\text { Zone } 4 \\
\text { Zone } 5 \\
\text { Zone } 6 \\
\text { Zone } 7\end{array}$ & $\mathrm{~g} / \mathrm{cm}^{3}$ & $\begin{array}{l}1.67 \\
1.64 \\
1.62 \\
1.61 \\
1.59 \\
1.58 \\
1.57\end{array}$ & $\begin{array}{l}\text { Calculated using } \\
\text { RESRAD defaults and } \\
\text { user assumptions (see } \\
\text { Attachment B.1) }\end{array}$ \\
\hline $\begin{array}{l}\text { Contaminated zone erosion rate } \\
\text { Zone } 1 \\
\text { Zone } 2 \\
\text { Zone } 3 \\
\text { Zone } 4 \\
\text { Zone } 5 \\
\text { Zone } 6 \\
\text { Zone } 7\end{array}$ & $\mathrm{~m} / \mathrm{yr}$ & $\begin{array}{l}9.33 \mathrm{E}-5 \\
9.33 \mathrm{E}-5 \\
9.33 \mathrm{E}-5 \\
9.33 \mathrm{E}-5 \\
1.87 \mathrm{E}-4 \\
1.87 \mathrm{E}-4 \\
5.60 \mathrm{E}-4\end{array}$ & $\begin{array}{l}\text { Shinn, } 1986 \text { and } \\
\text { Yu et al., } 1993 b\end{array}$ \\
\hline
\end{tabular}




\section{Table B.4-1 \\ Parameter Values Used in RESRAD for Calculating Dose to a Radiation Worker and an Industrial Worker on the Area 6 Decon Pond ${ }^{a}$} (Page 5 of 7 )

\begin{tabular}{|c|c|c|c|}
\hline Parameter & Unit & $\begin{array}{l}\text { Scenario } \\
\text { Value }\end{array}$ & Notes \\
\hline $\begin{array}{l}\text { Total porosity of contamination zone, } \\
\text { unsaturated zone, and saturated zone }\end{array}$ & Unitless & 0.4605 & DOE/NV, 1997 \\
\hline $\begin{array}{l}\text { Effective porosity of the contaminated, } \\
\text { unsaturated, and saturated zone }\end{array}$ & Unitless & 0.4605 & DOE/NV, 1997 \\
\hline $\begin{array}{l}\text { hydraulic conductivity of the contaminated, } \\
\text { unsaturated, and saturated zone }\end{array}$ & $\mathrm{m} / \mathrm{yr}$ & 0.078 & DOE/NV, 1997 \\
\hline $\begin{array}{l}\text { "b" parameter of the contaminated, } \\
\text { unsaturated, and saturated zone }\end{array}$ & Unitless & 4.05 & $\begin{array}{l}\text { Yu et al., 1993b } \\
\text { Table 13.1, page } 77\end{array}$ \\
\hline Evapotranspiration coefficient & Unitless & 0.69 & $\begin{array}{l}\text { Calculated using formula } \\
\text { in Yu et al., 1993b }\end{array}$ \\
\hline Precipitation & $\mathrm{m} / \mathrm{yr}$ & 0.15 & DOE/NV, 1996a \\
\hline Runoff coefficient & Unitless & 0.2 & $\begin{array}{l}\text { Yu et al., } 1993 \mathrm{~b} \\
\text { Table } 10.1\end{array}$ \\
\hline Watershed area for pond & $m^{2}$ & $3.72 E+3$ & $\begin{array}{l}\text { Minimum area for } \\
\text { RESRAD input. }\end{array}$ \\
\hline Accuracy for water/soil computations & Unitless & $1.00 \mathrm{E}-3$ & RESRAD default \\
\hline Saturated zone hydraulic gradient & Unitless & $1.00 \mathrm{E}-4$ & User assumption \\
\hline Water table drop rate & $\mathrm{m} / \mathrm{yr}$ & $1.0 \mathrm{E}-4$ & User assumption \\
\hline $\begin{array}{l}\text { Model: nondispersion (ND) or } \\
\text { mass balance (MB) }\end{array}$ & Unitless & ND & RESRAD default \\
\hline Number of unsaturated zones & Unitless & 1 & DOE/NV, 1997 \\
\hline Unsaturated zone thickness & $\mathrm{m}$ & 500 & DOE/NV, 1997 \\
\hline $\begin{array}{l}\text { Distribution coefficient (all zones) } \\
\text { Cobalt isotopes } \\
\text { Strontium isotopes } \\
\text { Cesium isotopes } \\
\text { Uranium isotopes } \\
\text { Plutonium isotopes } \\
\text { Americium isotopes } \\
\text { Actinium isotopes } \\
\text { Neptunium isotopes } \\
\text { Protactinium isotopes } \\
\text { Lead isotopes } \\
\text { Radium isotopes } \\
\text { Thorium isotopes }\end{array}$ & $\begin{array}{l}\mathrm{cm}^{3} / \mathrm{g} \\
\mathrm{cm}^{3} / \mathrm{g} \\
\mathrm{cm}^{3} / \mathrm{g} \\
\mathrm{cm}^{3} / \mathrm{g} \\
\mathrm{cm}^{3} / \mathrm{g} \\
\mathrm{cm}^{3} / \mathrm{g} \\
\mathrm{cm}^{3} / \mathrm{g} \\
\mathrm{cm}^{3} / \mathrm{g} \\
\mathrm{cm}^{3} / \mathrm{g} \\
\mathrm{cm}^{3} / \mathrm{g} \\
\mathrm{cm}^{3} / \mathrm{g} \\
\mathrm{cm}^{3} / \mathrm{g}\end{array}$ & $\begin{array}{c}60 \\
15 \\
280 \\
35 \\
550 \\
35 \\
450 \\
5 \\
550 \\
270 \\
500 \\
3,200 \\
\end{array}$ & Yu et al., 1993b \\
\hline
\end{tabular}




\section{Table B.4-1 \\ Parameter Values Used in RESRAD for Calculating Dose to a Radiation Worker and an Industrial Worker on the Area 6 Decon Pond ${ }^{a}$} (Page 6 of 7 )

\begin{tabular}{|c|c|c|c|}
\hline Parameter & Unit & $\begin{array}{l}\text { Scenario } \\
\text { Value }\end{array}$ & Notes \\
\hline $\begin{array}{l}\text { Inhalation rate } \\
\text { Industrial worker } \\
\text { Radiological worker }\end{array}$ & $\mathrm{m}^{3} / \mathrm{yr}$ & $\begin{array}{r}7,452 \\
13,666\end{array}$ & $\begin{array}{l}\text { Calculated from data in } \\
\text { Yu et al., 1993b, and } \\
\text { Layton, } 1993\end{array}$ \\
\hline $\begin{array}{l}\text { Mass loading for inhalation } \\
\text { Industrial worker } \\
\text { Radiological worker }\end{array}$ & $\mathrm{g} / \mathrm{m}^{3}$ & $\begin{array}{l}7.9 \mathrm{E}-5 \\
7.9 \mathrm{E}-5\end{array}$ & $\begin{array}{l}\text { Gilbert, } 1989 \text { for rural } \\
\text { areas, maximum value }\end{array}$ \\
\hline Dilution length for airborne dust inhalation & $\mathrm{m}$ & 3 & RESRAD default \\
\hline Exposure duration & years & 30 & RESRAD default \\
\hline $\begin{array}{l}\text { Shielding factor, inhalation } \\
\text { Industrial worker } \\
\text { Radiological worker }\end{array}$ & unitless & $\begin{array}{l}0.4 \\
1.0\end{array}$ & $\begin{array}{l}\text { RESRAD default } \\
\text { No shielding }\end{array}$ \\
\hline $\begin{array}{l}\text { Shielding factor from external radiation } \\
\text { Industrial worker } \\
\text { Radiological worker }\end{array}$ & unitless & $\begin{array}{l}0.7 \\
1.0 \\
\end{array}$ & $\begin{array}{l}\text { RESRAD default } \\
\text { No shielding }\end{array}$ \\
\hline $\begin{array}{l}\text { Fraction of time spent indoors on the DPF } \\
\text { Industrial worker } \\
\text { Radiological worker }\end{array}$ & unitless & $\begin{array}{l}0.2283 \\
0.0\end{array}$ & User assumption \\
\hline $\begin{array}{l}\text { Fraction of time spent outdoors, on DPF } \\
\text { Industrial worker } \\
\text { Radiological worker }\end{array}$ & unitless & $\begin{array}{l}0.0 \\
1.0\end{array}$ & $\begin{array}{l}\text { User assumptions } \\
\text { regarding both scenarios }\end{array}$ \\
\hline Shape factor flag, external gamma & unitless & 1 & RESRAD default \\
\hline $\begin{array}{l}\text { Soil ingestion rate } \\
\text { Industrial worker } \\
\text { Radiological worker }\end{array}$ & $\mathrm{g} / \mathrm{yr}$ & $\begin{array}{l}18.25 \\
18.25\end{array}$ & DOE/NV, 1996a \\
\hline $\begin{array}{l}\text { Depth of soil mixing layer } \\
\text { Industrial worker } \\
\text { Radiological worker }\end{array}$ & $\mathrm{m}$ & $\begin{array}{l}0.15 \\
0.15\end{array}$ & RESRAD default \\
\hline Thickness of building foundation & $\mathrm{m}$ & 0.15 & RESRAD default \\
\hline Bulk density of building foundation & $\mathrm{g} / \mathrm{cm}^{3}$ & 2.4 & RESRAD default \\
\hline Total porosity of building foundation & Unitless & 0.1 & RESRAD default \\
\hline Volumetric water content of the foundation & Unitless & 3.0E-2 & RESRAD default \\
\hline $\begin{array}{l}\text { Diffusion coefficient for radon gas } \\
\text { in foundation material } \\
\text { in contaminated zone soil }\end{array}$ & $\mathrm{m} / \mathrm{s}$ & $\begin{array}{l}3.0 \mathrm{E}-7 \\
2.0 \mathrm{E}-6\end{array}$ & $\begin{array}{l}\text { RESRAD default } \\
\text { RESRAD default }\end{array}$ \\
\hline Radon vertical dimension of mixing & $\mathrm{m}$ & 2 & RESRAD default \\
\hline
\end{tabular}


Table B.4-1

Parameter Values Used in RESRAD for Calculating Dose to a Radiation Worker and an Industrial Worker on the Area 6 Decon Pond ${ }^{a}$ (Page 7 of 7 )

\begin{tabular}{|c|c|c|c|}
\hline Parameter & Unit & $\begin{array}{c}\text { Scenario } \\
\text { Value }\end{array}$ & Notes \\
\hline Total porosity of the cover material & Unitless & 0.4605 & DOE/NV, 1997 \\
\hline Average annual wind speed & $\mathrm{m} / \mathrm{s}$ & 3.1 & $\mathrm{DOE} / \mathrm{NV}, 1996 \mathrm{a}$ \\
\hline Average building air exchange rate & per hour & 0.5 & RESRAD default \\
\hline Height of the building (room) & $\mathrm{m}$ & 2.5 & RESRAD default \\
\hline Building interior area factor & Unitless & 0.0 & RESRAD default \\
\hline Building depth below ground surface & $\mathrm{m}$ & 0 & User assumption \\
\hline $\begin{array}{l}\text { Summary of pathways selected } \\
\text { external gamma } \\
\text { inhalation without radon } \\
\text { soil ingestion } \\
\text { radon }\end{array}$ & NA & NA & $\begin{array}{l}\text { Scenario dependent } \\
\text { both scenarios } \\
\text { both scenarios } \\
\text { both scenarios } \\
\text { both scenarios }\end{array}$ \\
\hline
\end{tabular}

${ }_{b}^{a}$ Scenario-specific data is noted in the parameter column. All other data is pertinent to all three scenarios.

bESRAD defaults defined in Yu et al., 1993a and 1993b.

NA = Not applicable 
Modeling the airborne exposure pathway segment consists of two steps: (1) modeling the process by which radionuclides become airborne, and (2) modeling the process by which the airborne radionuclides are transported to the dose receptor location and diluted before inhalation. The first step gives the ratio of the airborne emission near the source before it is dispersed and diluted to the concentration in the resuspendable layer of soil. The second step gives the ratio of the airborne concentration at the point of exposure to the airborne emission at the source. Quantitative details of the RESRAD calculation of the exposure point concentration can be found in Appendix B, C, and L of the RESRAD User's Manual (Yu et al., 1993a). RESRAD userdefined input parameter values for the inhalation pathway exposure point concentrations are found in Table B.4-2. The calculations used in compute the RESRAD input are listed in Attachment B.1.

\section{B.4.2 External Radiation Pathway}

Radiation from photons and gamma rays emitted from radionuclides distributed throughout the contaminated soil is the dominant external radiation pathway and the only external pathway included in this assessment. The dose due to external gamma radiation is first calculated for an individual exposed continuously to radiation from an infinitely contaminated zone at a distance of $1 \mathrm{~m}(3.3 \mathrm{ft})$ above the ground surface. Correction factors are then applied for the finite area and thickness of the contaminated zone, shielding by a cover of uncontaminated soil, shielding by the floors and walls of a building, and less-than-continuous occupancy. Quantitative details are presented in Section 3.0 and Appendix A of the RESRAD users manual (Yu et al., 1993a). All RESRAD user-defined input parameter values for the external radiation pathway exposure point concentrations are found in Table B.4-1. The calculations used to compute the RESRAD input are listed in Attachment B.1.

\section{B.4.3 Soil Ingestion}

The soil ingestion pathway corresponds to direct ingestion of soil (Healy, 1977). The dose receptors are assumed to inadvertently ingest soil primarily through dermal contact of their hands with the soil or contaminated dust and then touching their mouth or nose. Quantitative details are presented in Appendix F of the RESRAD users manual (Yu et al., 1993a). RESRAD userdefined input parameter values for the soil ingestion pathway exposure point concentrations are found in Table B.4-1. The calculations used to compute the RESRAD input are listed in Attachment B.1. 


\section{B.4.4 RESRAD Model for the DPF Contamination Zones}

RESRAD calculates dose and soil guidelines based upon a user-defined contamination zone. A contamination zone is defined as a below-ground region with radionuclides present above background concentrations and is the common source term and starting point for all pathways. RESRAD assumes the contamination zone is an idealized region of cylindrical shape with uniformly distributed radionuclides. A cover depth can be modeled by RESRAD by equating the cover thickness to the distance from the ground surface to the top of the uppermost contaminated zone.

As described in Section B.2.0, the DPF is partitioned into eight contamination zones. The thickness of each zone and the concentration of the radionuclides in the zone are listed in Table B.3-3. RESRAD is capable of computing dose from only one contamination zone. For the purpose of modeling the DPF, separate RESRAD computations were performed for each zone. RESRAD was used to compute the dose from each zone with and without an engineered cap for both the radiological worker and the industrial worker exposure scenarios. The computed doses were summed over all eight zones.

Quantitative details on the way RESRAD models a contaminated zone are presented in Section 3.1 and 3.2 of the RESRAD User's Manual (Yu et al., 1993a). RESRAD user-defined input parameter values for the radionuclide distribution in the contaminated zones are found in Tables B.3-3 and B.4-1. The calculations used to compute the RESRAD input are listed in Attachment B.1.

\section{B.4.5 Time Dependance of the Exposure Point Concentration}

The time dependence of the exposure point concentration of a radionuclide is controlled by the following factors:

- Rate at which radionuclides are leached from the contaminated zone

- Rate of erosion of the cover and contaminated soil

- Rate of environmental transport through the environmental pathways

- Rate of ingrowth and decay of the radionuclide.

The first and second processes occur within, or primarily within, the contaminated zone; the third process occurs outside the contaminated zone; and the last process occurs in all zones. The RESRAD models used to account for the time dependence of different transport and erosion processes are described in Appendices A through F, H, and K of the RESRAD User's Manual 
(Yu et al., 1993a). The models used to account for the rate of radiological ingrowth and decay and the leaching of radionuclides from the contaminated zone are described in Appendices $\mathrm{G}$ and I of the RESRAD User's Manual (Yu et al., 1993a). RESRAD user-defined input parameter values that affect the time dependence of the exposure point concentration are found in Table B.4-1. The calculations used to compute the RESRAD input are listed in Attachment B.1. 


\section{B.5.0 Dose Assessment}

The dose that is regulated by the DOE, NRC, and the EPA is defined as the total effective dose equivalent (TEDE) and includes the contribution from exposure to radionuclides inside and outside the body. Different types and energies of radiation will result in different patterns of energy absorption. In addition, individual tissues and organs in the body respond differently to absorbed radiation. The distribution of dose within the body depends on the type of radiation involved and the location of the radionuclides emitting the radiation, whether they are external or internal to the body.

The ICRP has provided a useful quantity that, on a risk scale, can be applied to any radiation pattern (ICRP, 1977, 1978, 1979-1982, 1991a, 1991b). This quantity, the EDE, is the weighted sum of the dose equivalent in various organs from external and internal exposure. The weighing factors for the organs are proportional risks associated with the irradiation of those organs. All dose factors used for calculating dose are based upon the EDE.

Internal doses to organs and tissues of the body are frequently estimated with factors representing the committed effective dose equivalent for a unit intake of a radionuclide via inhalation or ingestion. The committed dose equivalent is the dose equivalent to organs or tissues that will be received by an individual from an intake of radioactive material during the 50-year period following the intake.

The sum of the EDE from external exposure and the committed EDE from internal exposure is defined as the TEDE. The TEDE is the quantity that is computed for this assessment.

In the case of external radiation, the dose rate in organs and tissues depends on the concentration of the radionuclides in the soil and air at the DPF. These relationships are expressed as dose/exposure ratios called "dose conversion factors" (DCFs). A DCF is the ratio of the committed EDE for internal exposure or the EDE rate for external exposure to the quantity of a radionuclide inhaled or ingested for internal exposure or the concentration of a radionuclide in the air or soil for external exposure.

Sections B.5.1 through B.5.4 describe the method RESRAD uses to calculate dose from inhalation, ingestion, external exposure, and radon daughter products. Section B.5.5 describes 
metabolic processes and physical decay and their affect on the dose. Section B.5.6 summarizes dose calculations.

\section{B.5.1 Dose Methodology for Inhalation}

Dose equivalents in organs or tissues of the body are calculated by RESRAD with models that describe the following:

- Entrance rate of radionuclides into the body

- Deposition and subsequent retention of radionuclides in body organs

- Estimates of the energy deposited in the tissues and organs of the body.

Inhalation of radionuclides attached to airborne particles is a route for intake of radionuclides into the body for the dose receptors at the DPF. RESRAD has adopted the ICRP lung model for calculating inhalation dose. The ICRP model of the respiratory tract divides the tract into three regions: nasopharyngeal, tracheobronchial, and pulmonary (ICRP, 1966). These regions are connected with one another as well as with body fluids and the gastrointestinal tract (GI). The fraction of inhaled activity deposited in these regions is a function of the size of the airborne particles. The activity median aerodynamic diameter is the measure most widely used to characterize the aerosol. In this assessment, based on the recommendation of the ICRP, a particle size distribution of a mean of 1 micrometer $(\mu \mathrm{m})$ with a geometric standard deviation of 2 was assumed.

The rate at which the deposited material is removed from the regions is considered to be independent of particle size; it is however, related to the chemical form of the particles. Chemical compounds are assigned to one of three classes to characterize their removal rate from the lung. The inhalation classes are denoted as D, W, and Y. These letters correspond to clearance or removal times from the pulmonary region of the lung on the order of days, weeks, or years, respectively. Details are provided in the ICRP task group's report (ICRP, 1966) and subsequent ICRP publications (ICRP 1979, 1982, 1991a, and 1991b). Details on the method for calculating the dose from the inhalation of airborne contaminated soil are found in Table B.5-1. In this assessment, the clearance class chosen for each radionuclide results in the maximum dose conversion factor for that radionuclide. The inhalation dose conversion factors and clearance classes for each radionuclide that were used in this assessment are listed in Table B.5-2. 


\section{Table B.5-1 \\ Method for Calculating Dose from the Inhalation of Airborne Soil}

$\mathrm{CEDE}_{\mathrm{INH}}(\mathrm{mrem} / \mathrm{yr})=\sum \mathrm{DCF}_{\mathrm{j} 2} \times \mathrm{ETF}_{\mathrm{j} 2} \times \mathrm{Sf}_{\mathrm{ij}}$

where:

$$
\begin{aligned}
\mathrm{CEDE}_{\mathrm{INH}}= & \text { Committed Effective Dose Equivalent from inhalation of contaminated soil } \\
\mathrm{DCF}_{\mathrm{j} 2}= & \text { CEDE conversion factors }(\mathrm{mrem} / \mathrm{pCi})^{\mathrm{a}} \text { listed in Table B.5-2 for inhalation } \\
\mathrm{ETF}_{\mathrm{j} 2}= & \begin{array}{l}
\text { Ratio of the annual intake, } \mathrm{E}_{\mathrm{i2}}(\mathrm{t}), \text { of the jth principal radionuclide by soil inhalation to } \\
\text { the concentration, } \mathrm{S}_{\mathrm{i}}(\mathrm{t}), \text { of that radionuclide in the soil for the th year following }
\end{array} \\
& \begin{array}{l}
\text { closure. It is also known as the environmental transfer factor for inhalation and can } \\
\text { be expressed as the following product: }
\end{array} \\
\mathrm{ETF}_{\mathrm{j} 2}= & \mathrm{ASR}_{2} \times \mathrm{FA}_{2} \times \mathrm{FCD}_{2}(\mathrm{t}) \times \mathrm{FO}_{2} \times \mathrm{Fl}_{2}
\end{aligned}
$$

where:

$\mathrm{ASR}_{2}=$ average mass loading of airborne contaminated soil $\left(7.9 \mathrm{E}-5 \mathrm{~g} / \mathrm{m}^{3}\right)$, the highest value for nonurban areas listed in Yu et al. (1993b)

$\mathrm{FA}_{2}=$ Area factor $=(\mathrm{A})^{1 / 2} /\left[(\mathrm{A})^{1 / 2}+\mathrm{DL}\right]$

where:

A $=$ area of the Area 6 Decon Pond $\left(3716 \mathrm{~m}^{2}\right)$

$\mathrm{DL}=$ Dilution length $(3 \mathrm{~m})$

$\mathrm{FCD}_{2}(\mathrm{t})=$ cover and depth factor (dimensionless)

where:

$$
\begin{aligned}
\mathrm{FCD}_{2}(\mathrm{t}) & =1 \text { when } \mathrm{C}=0 \\
& =\mathrm{T} / \mathrm{d} \text { when } \mathrm{C}(t)+\mathrm{T}(t)<\mathrm{d} \\
& =1-\mathrm{C}(t) / \mathrm{d} \text { when } \mathrm{C}(t)<\mathrm{d}, \mathrm{C}(t)+\mathrm{T}(t) \geq \mathrm{d} \\
& =0 \text { when } \mathrm{C}(t) \geq \mathrm{d}
\end{aligned}
$$

$\mathrm{C}(\mathrm{t})=$ cover depth at time $(t)(\mathrm{m})$

$\mathrm{d}=$ depth of soil mixing layer $(0.15 \mathrm{~m})$

$\mathrm{T}(\mathrm{t})=$ thickness of contaminated zone at time $(t)(\mathrm{m})$

$\mathrm{FO}_{2}=$ fraction of the time the dose receptor is at the Decon Pond

$\mathrm{FI}_{2}=$ annual intake of air by the dose receptor $\left(\mathrm{m}^{3} / \mathrm{yr}\right)$

$\mathrm{Sf}_{\mathrm{i}}=$ factor for ingrowth and decay and leaching of the $t$ th principal radionuclide at time $t$ from the ith principal radionuclide present initially (see pg 38 of Yu et al., 1993a for details). 
Table B.5-2

Committed Effective Dose Equivalent Conversion Factors for Inhalation

\begin{tabular}{|c|c|c|}
\hline Isotope & $\begin{array}{l}\text { Dose Conversion Factor } \\
(\mathrm{mrem} / \mathrm{pCi})^{\mathrm{a}}\end{array}$ & Lung Clearance Class \\
\hline Cobalt- 60 & $2.19 \times 10^{-4}$ & $Y$ \\
\hline Strontium-90+D & $1.31 \times 10^{-3}$ & $\mathrm{Y}$ \\
\hline Cesium-137 + D & $3.19 \times 10^{-5}$ & $\mathrm{D}$ \\
\hline Lead-210 + D & $2.32 \times 10^{-2}$ & $\mathrm{D}$ \\
\hline Lead-212 & $1.69 \times 10^{-4}$ & $\mathrm{D}$ \\
\hline Radium-226 + D & $8.60 \times 10^{-3}$ & W \\
\hline${ }^{*}$ Radium-228 + D & $5.08 \times 10^{-3}$ & W \\
\hline${ }^{*}$ Actinium-227 + D & $6.72 \times 10^{0}$ & $\mathrm{D}$ \\
\hline Actinium-228 & $1.22 \times 10^{-4}$ & $\mathrm{Y}$ \\
\hline *Thorium-228 + D & $3.45 \times 10^{-1}$ & $\mathrm{Y}$ \\
\hline${ }^{*}$ Thorium-229 + D & $2.16 \times 10^{0}$ & Y \\
\hline *Thorium-230 & $3.26 \times 10^{-1}$ & W \\
\hline Thorium-234 & $3.50 \times 10^{-5}$ & $\mathrm{Y}$ \\
\hline Protactinium-231 & $1.28 \times 10^{0}$ & W \\
\hline${ }^{*}$ Neptunium-237 + D & $5.40 \times 10^{-1}$ & W \\
\hline Americium-241 & $4.44 \times 10^{-1}$ & W \\
\hline *Uranium-233 & $1.33 \times 10^{-1}$ & $\mathrm{Y}$ \\
\hline *Uranium-234 & $1.32 \times 10^{-1}$ & $\mathrm{Y}$ \\
\hline *Uranium-235 + D & $1.23 \times 10^{-1}$ & $\mathrm{Y}$ \\
\hline *Uranium-236 & $1.25 \times 10^{-1}$ & $\mathrm{Y}$ \\
\hline Plutonium-238 & $3.92 \times 10^{-1}$ & W \\
\hline Plutonium-239 & $4.29 \times 10^{-1}$ & W \\
\hline Plutonium-240 & $4.29 \times 10^{-1}$ & W \\
\hline
\end{tabular}

${ }^{a}$ Millirem per picocurie

Isotope $+\mathrm{D}$ means the Dose Conversion Factor includes the contributions from all of its decay products.

An asterisk $\left({ }^{*}\right)$ means an isotope is a decay product of a principal radionuclide.

$\mathrm{Y}=$ Year

$\mathrm{D}=$ Day

$\mathrm{W}=$ Week 


\section{B.5.2 Dose from Ingestion of Radionuclides}

A portion of the material initially deposited in the lung enters the GI tract; radionuclides ingested with the soil from the DPF enter the GI tract directly. RESRAD has adopted the ICRP model of the GI tract which divides the GI tract into four compartments: stomach, small intestine, upper large intestine, and lower large intestine (Eve, 1966). Absorption of radionuclides into body fluids is generally considered to occur within the small intestine. The fraction of the ingested material absorbed into body fluids from the GI tract is denoted as $\mathrm{f}_{1}$. The numerical value of $\mathrm{f}_{1}$ depends on the chemical form of the ingested material (ICRP 1979 - 1982). Since the chemical forms of the radionuclides in the soil at the DPF are not known, the maximum $\mathrm{f}_{1}$ value for each radionuclide was used in this assessment. A summary of the method for calculating the dose from the ingestion of contaminated soil is found in Table B.5-3. The $\mathrm{f}_{1}$ value and dose conversion factor for each radionuclide used in calculating the dose from the ingestion of DPF soil are listed in Table B.5-4. Additional details can be found in Appendix D of the RESRAD users manual (Yu et al., 1993a).

\section{B.5.3 Dose from External Exposure}

Organs of the dose receptor may be irradiated by radiation emitted from radionuclides present in the soil at the DPF. Gamma radiation is the only external radiation considered in this assessment. Gamma radiation is sufficiently penetrating that the dose at a given location depends on the spatial distribution over considerable distances. In addition, the dose distribution pattern within the body is rather uniform. The actual distribution of dose in the body depends somewhat on the distribution pattern of the radionuclides in the soil at the DPF. That is one reason the radionuclide concentration in the soil at the DPF was partitioned into eight zones. Each zone is a different distance from the ground zero. Within each zone, the radionuclides are assumed to be uniformly distributed within a right, circular cylinder. RESRAD uses the methods of Kocher (1983), Kocher and Sjoreen (1985), and Chen (1991) to derive dose-rate factors of radionuclides uniformly distributed in the soil volume. The DCFs for soil contamination are for exposure at a point $1 \mathrm{~m}(3.3 \mathrm{ft})$ above the ground surface, for a volume that is assumed to be uniformly contaminated to an infinite depth and infinite lateral extent, and include the contributions of decay products. The methodology used in calculating the dose from external exposure for a finite volume and surface area is summed up in Table B.5-5. The DCFs used in 
where:

$$
\begin{aligned}
& \mathrm{DSR}_{\mathrm{i}}(\mathrm{t})=\text { dose to source ratio }(\mathrm{mrem} / \mathrm{yr}) /(\mathrm{pCi} / \mathrm{g}) \\
& \mathrm{DCF}_{\mathrm{j} 8}=\text { dose to exposure ratio from ingestion of isotope } \mathrm{j}(\mathrm{mrem} / \mathrm{pCi})^{\mathrm{a}} \text {; listed in Table B.5-4 } \\
& \mathrm{ETF}_{\mathrm{j} 8} \quad=\text { isotope ingested rate to its concentration in DPF soil }(\mathrm{pCi} / \mathrm{yr})^{\mathrm{b}} /(\mathrm{pCi} / \mathrm{g}) \\
& \text { where: } \\
& \mathrm{ETF}_{\mathrm{j} 8}(t)=\mathrm{FSI} \times \mathrm{FA}_{8} \times \mathrm{FCD}_{8}(t) \times \mathrm{FO}_{8} \\
& \text { where: } \\
& \mathrm{ETF}_{j 8}(t)=\text { environmental transfer factor at time } t \text { for the } j \text { th principal radionuclide } \\
& \text { ( } g / y r) \\
& \mathrm{S}_{\mathrm{j}}(\mathrm{t}) \quad=\text { concentration of principle radionuclide } j \text { at time } t \text { at DPF }(\mathrm{pCi} / \mathrm{g}) \\
& \mathrm{FSI} \quad=\text { annual intake of soil }(18.5 \mathrm{~g} / \mathrm{yr}) \\
& \mathrm{FA}_{8} \quad=\text { area factor }=1 \text { for the DPF } \\
& \mathrm{FCD}_{\mathrm{s}}(t)=\text { cover and depth factor (dimensionless) } \\
& \mathrm{FO}_{8}=\text { occupancy factor (dimensionless) } \\
& \text { radiological worker } \mathrm{FO}_{8}=0.000943 \\
& \text { industrial worker } \mathrm{FO}_{8}=0.23
\end{aligned}
$$

Additional detail and information can be found in Section 3.2 and Appendix F of the RESRAD users manual (Yu et al., 1993a). 
Table B.5-4

Committed Effective Dose Equivalent Conversion Factors for Ingestion

\begin{tabular}{|c|c|c|}
\hline Isotope & $\begin{array}{l}\text { Dose Conversion Factor } \\
(\mathrm{mrem} / \mathrm{pCi})^{\mathrm{a}}\end{array}$ & $f_{1}^{b}$ \\
\hline Cobalt-60 & $2.69 \times 10^{-5}$ & $3 \times 10^{-1}$ \\
\hline Strontium-90+D & $1.53 \times 10^{-4}$ & $3 \times 10^{-1}$ \\
\hline Cesium-137 + D & $5.00 \times 10^{-5}$ & 1 \\
\hline Lead-210 + D & $7.27 \times 10^{-3}$ & $2 \times 10^{-1}$ \\
\hline Lead- $212^{c}$ & $2.73 \times 10^{-3}$ & $2 \times 10^{-1}$ \\
\hline Radium-226 + D & $1.33 \times 10^{-3}$ & $2 \times 10^{-1}$ \\
\hline${ }^{*}$ Radium-228 + D & $1.44 \times 10^{-3}$ & $2 \times 10^{-1}$ \\
\hline${ }^{*}$ Actinium-227 + D & $1.48 \times 10^{-2}$ & $1 \times 10^{-3}$ \\
\hline Actinium-228 & $2.73 \times 10^{-3}$ & $1 \times 10^{-3}$ \\
\hline${ }^{*}$ Thorium $-228+D$ & $8.08 \times 10^{-4}$ & $2 \times 10^{-4}$ \\
\hline *Thorium-229 + D & $4.03 \times 10^{-3}$ & $2 \times 10^{-4}$ \\
\hline${ }^{*}$ Thorium-230 & $5.48 \times 10^{-4}$ & $2 \times 10^{-4}$ \\
\hline Thorium-234 ${ }^{\mathrm{d}}$ & $2.55 \times 10^{-4}$ & $2 \times 10^{-4}$ \\
\hline Protactinium-231 & $1.06 \times 10^{-2}$ & $1 \times 10^{-3}$ \\
\hline${ }^{*}$ Neptunium-237 + D & $4.44 \times 10^{-3}$ & $1 \times 10^{-3}$ \\
\hline Americium-241 & $3.64 \times 10^{-3}$ & $1 \times 10^{-3}$ \\
\hline *Uranium-233 & $2.89 \times 10^{-4}$ & $5 \times 10^{-2}$ \\
\hline *Uranium-234 & $2.83 \times 10^{-4}$ & $5 \times 10^{-2}$ \\
\hline *Uranium-235 + D & $2.67 \times 10^{-4}$ & $5 \times 10^{-2}$ \\
\hline *Uranium-236 & $2.69 \times 10^{-4}$ & $5 \times 10^{-2}$ \\
\hline Plutonium-238 & $3.20 \times 10^{-3}$ & $1 \times 10^{-3}$ \\
\hline Plutonium-239 & $3.54 \times 10^{-3}$ & $1 \times 10^{-3}$ \\
\hline Plutonium-240 & $3.54 \times 10^{-3}$ & $1 \times 10^{-3}$ \\
\hline
\end{tabular}

\footnotetext{
${ }^{a}$ Millirem per picocurie

${ }^{b}$ Fraction of a radionuclide that passes through the gastrointestinal wall and is absorbed by the blood

${ }^{\mathrm{C}}$ RESRAD does not list a dose conversion factor of lead-212 or actinium-228. The values for their long-lived principal parent radionuclide, thorium-232, are used (Yu et al., 1993a).

RESRAD does not list a dose conversion factor for Thorium-234; the value for its long-lived principal parent radionuclide, uranium-238, is used (Yu et al., 1993a).
}

Isotope + D means the Dose Conversion Factor includes the contributions from all of its decay products.

An asterisk ( $\left.{ }^{*}\right)$ means an isotope is a decay product of a principal radionuclide. 
Table B.5-5

Method for Calculating External Dose from Radionuclides in the Ground

$\mathrm{DSR}_{\mathrm{ij}}(t)(\mathrm{mrem} / \mathrm{yr}) /\left(\mathrm{pCi} / \mathrm{cm}^{3}\right)=\sum \mathrm{DCF}_{\mathrm{j} 1} \times \mathrm{ETF}_{\mathrm{j} 1} \times \mathrm{Sf}_{\mathrm{ij}}$

where:

$\mathrm{DSR}_{\mathrm{ij}}(t)=$ dose to source ratio of the effective dose equivalent from external ground radiation from the th principal radionuclide at time $t$

$\mathrm{DCF}_{\mathrm{j} 1}=$ Dose conversion factor for the external ground radiation pathway from the th principal radionuclide present at unit concentration in a uniformly contaminated zone of infinite depth and lateral extent

$\mathrm{ETF}_{\mathrm{j} 1}=$ environmental transfer factor

$=\rho_{\mathrm{b}} \times \mathrm{FO}_{1} \times \mathrm{FS}_{1} \times \mathrm{FA}_{1} \times \mathrm{FD}_{1 \mathrm{i}}(t) \times \mathrm{FC}_{1 \mathrm{i}}(t)$

where:

$\rho_{\mathrm{b}} \quad=$ bulk density of soil $\left(1.5 \mathrm{~g} / \mathrm{cm}^{3}\right)$

$\mathrm{FO}_{1} \quad=$ occupancy and shielding factors

radiological worker occupancy factor $=.000943$

radiological worker shielding factors $=1$ external exposure

industrial worker occupancy factor $=0.23$

industrial worker shielding factors $=0.7$ for external exposure

$\mathrm{FA}_{1} \quad=$ area factor (dimensionless)

$\mathrm{FS}_{1} \quad=$ shape factor (1.0, dimensionless)

$\mathrm{FD}_{1 \mathrm{i}}(t)=$ depth factor for radionuclide $i$ at time $t$ (dimensionless)

where:

$\mathrm{FD}_{1 \mathrm{i}}(t)=1-\exp \left[-k_{i} \mathrm{\rho}_{\mathrm{b}} \mathrm{T}(t)\right]$

$k=$ an empirical constant $\left(\mathrm{m}^{2} / \mathrm{kg}\right)$

$\mathrm{T}(\mathrm{t})=$ thickness of contaminated zone at time $t(\mathrm{~m})$

$\mathrm{FC}_{1 \mathrm{j}}(t)=$ cover factor for radionuclide $i$ at time $t$ (dimensionless)

$F C_{1 i}(t)=\exp \left[-k_{i} \rho_{b} C_{d}(t)\right]$

where:

$\mathrm{C}_{\mathrm{d}} \quad=$ cover depth at time $t(\mathrm{~m})$

$\mathrm{Sf}_{\mathrm{ij}}=$ source factor, see Table 5 and page 38 of Yu et. al., (1993a) 
this assessment for external exposure are listed in Table B.5-6. Additional details are in Appendix A of the RESRAD User's Manual (Yu et al., 1993a).

\section{B.5.4 Doses from Radon Decay Products}

The inhalation of radon decay products is the dominant dose contributor at the DPF for the industrial worker and for the radiological worker under the engineered cap alternative.

Calculation of the EDEs from airborne radon and radon decay products requires an estimate of the following:

- Radon gas exhalation rate from the ground surface

- Radon concentration in the air that results from this flux

- Airborne concentration of radon decay products associated with this concentration.

The radon gas release rate from the ground surface varies with the local distribution of radium in the soil, soil type, moisture content of the soil, and meteorological factors such as barometric pressure, wind speed, and air turbulence. RESRAD calculates the rate of radon generation from the radon emanation coefficient, the total porosity of the soil, the diffusion coefficient of radon in soil, the axial distance in the direction of diffusion, the bulk density of the soil, the radium concentration in soil, the radon decay constant, and area factors derived from the area of the DPF. A detailed summary of the methodology used in calculating the concentration of radon decay products in outdoor and indoor air is found in Table B.5-7. Additional details can be found in Appendix C of the RESRAD User's Manual (Yu et al., 1993). The methodology used in calculating the dose from the inhalation of radon decay products is listed in Table B.5-8.

\section{B.5.5 Metabolic Process and Radioactive Decay}

Radionuclides that enter body fluids from either the lungs or the GI tract may be deposited within the organs of the body. Metabolic processes and radioactive decay reduce the radioactivity in the body, and these removal processes are modeled by RESRAD. The organs are represented by a number of mathematical compartments from which the removal rate is directly proportional to the amount of radionuclide present (ICRP, 1979 - 1982). This approach involves summing exponentials to describe the time course of radioactivity within the body. The exception to this representation occurs for radium, where the more-detailed metabolic model of ICRP Publication 20 is used (ICRP, 1972). 
Table B.5-6 Effective Dose Equivalent Conversion Factors $\left(\mathrm{DCF}_{\mathrm{ji}}\right)$
for External Gamma from Contaminated Soil

\begin{tabular}{|c|c|c|c|}
\hline \multirow{2}{*}{ Radionuclide } & \multirow{2}{*}{$\begin{array}{l}\text { Surface Factors } \\
(\mathrm{mrem} / \mathrm{yr}) /\left(\mathrm{pCi} / \mathrm{cm}^{2}\right)\end{array}$} & \multicolumn{2}{|c|}{$\begin{array}{l}\text { Volume Factors } \\
(\mathrm{mrem} / \mathrm{yr}) /\left(\mathrm{pCi} / \mathrm{cm}^{3}\right)\end{array}$} \\
\hline & & $\begin{array}{l}\rho_{\mathrm{b}}=1.0 \\
\left(\mathrm{~g} / \mathrm{cm}^{3}\right)\end{array}$ & $\begin{array}{c}\rho_{b}=1.8 \\
\left(\mathrm{~g} / \mathrm{cm}^{3}\right)\end{array}$ \\
\hline Cobalt-60 & 2.27 & $2.27 \times 10^{1}$ & $1.25 \times 10^{1}$ \\
\hline Strontium-90 + D & 0 & 0 & 0 \\
\hline Cesium-137 + D & $6.11 \times 10^{-1}$ & 5.03 & 2.77 \\
\hline Lead-210 + D & $3.01 \times 10^{-3}$ & $4.87 \times 10^{-3}$ & $2.31 \times 10^{-3}$ \\
\hline Lead-212 ${ }^{\mathrm{a}}$ & $6.66 \times 10^{-4}$ & $1.35 \times 10^{-3}$ & $6.04 \times 10^{-4}$ \\
\hline Radium-226 + D & 1.68 & $1.55 \times 10^{1}$ & 8.56 \\
\hline Actinium-228 ${ }^{a}$ & $6.66 \times 10^{-4}$ & $1.35 \times 10^{-3}$ & $6.04 \times 10^{-4}$ \\
\hline Thorium-234 ${ }^{\mathrm{b}}$ & $2.59 \times 10^{-2}$ & $1.27 \times 10^{-1}$ & $6.97 \times 10^{-2}$ \\
\hline Americium-241 & $2.99 \times 10^{-2}$ & $4.79 \times 10^{-2}$ & $2.58 \times 10^{-2}$ \\
\hline Plutonium-238 & $8.58 \times 10^{-4}$ & $1.56 \times 10^{-3}$ & $6.65 \times 10^{-4}$ \\
\hline Plutonium-239 & $3.78 \times 10^{-4}$ & $8.14 \times 10^{-4}$ & $3.76 \times 10^{-4}$ \\
\hline Plutonium-240 & $8.20 \times 10^{-4}$ & $1.48 \times 10^{-3}$ & $6.35 \times 10^{-4}$ \\
\hline
\end{tabular}

${ }^{a}$ RESRAD does not list a $D_{C F}$ for lead-212 and actinium-228; the values for their long-lived principal parent radionuclide, thorium-232, are used.

${ }_{\text {RESRAD does not list a } D C F_{j 1}}$ for thorium-234; the value for its long-lived principal parent radionuclide, uranium-238, is used.

The $\mathrm{DCF}_{\mathrm{j} 1}$ for every radioactive decay product is the RESRAD default $D C F_{\mathrm{j} 1}$ 
where:

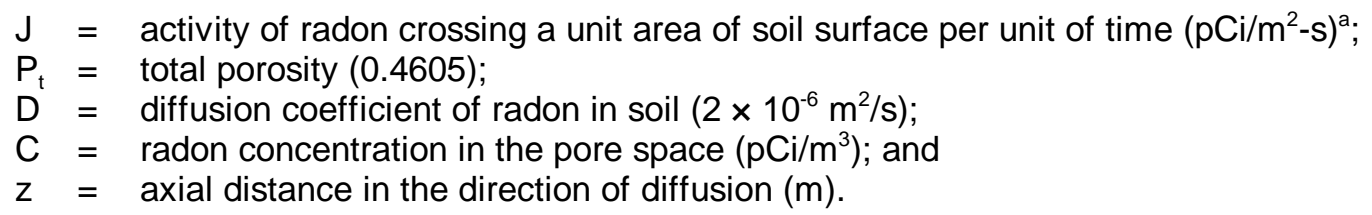

A one-dimensional radon diffusion equation is used to calculate flux

$$
d C / d t=d / d z(D d C / d z)-\Lambda C+Q
$$

where:

$\mathrm{t}=\mathrm{time}(\mathrm{s})$

$\Lambda=$ radon decay constant $\left(2.098 \times 10^{-6}\right.$ fraction per second for $\left.{ }^{222} \mathrm{Rn}\right)$; and

$\mathrm{Q}=$ radon source term in the pore space $\left(\mathrm{pCi} / \mathrm{m}^{3}-\mathrm{s}\right)$.

Assuming steady state conditions, Equation 5 can be written as

$$
-d / d z(D d c / d z)+\lambda C=Q
$$

The rate of radon generation into the pore volume, $\mathrm{Q}$, can then be calculated by:

$$
Q=\left(\varepsilon p_{b} S_{r a} \lambda\right) / p_{t}
$$

where:

$\varepsilon=$ radon emanation coefficient (dimensionless); the fraction of the radon that gets into the soil; pore space $\left(0.2\right.$ for ${ }^{222} \mathrm{Rn}$ and 0.15 for $\left.{ }^{220} \mathrm{Rn}\right)$;

$\mathrm{p}_{\mathrm{b}}=$ bulk density of the soil $\left(1,500 \mathrm{~kg} / \mathrm{m}^{3}\right)$;

$\mathrm{S}_{\mathrm{ra}}=$ radium concentration in soil zone $(\mathrm{pCi} / \mathrm{kg})$ [Table B.4-1 has ${ }^{226} \mathrm{Ra}$ concentration in $\left.\mathrm{pCi} / \mathrm{g}\right]$;

$\Lambda=$ radon decay constant $\left(2.098 \times 10^{-6}\right.$ fraction per second for $\left.{ }^{222} \mathrm{Rn}\right)$.

Boundary conditions for solving Eq. 7 are as follows:

$C\left(Z_{a}\right)=0$, the radon concentration at either the air-ground or floor interfaces, $Z_{a}$, is zero

$\mathrm{J}(0) \quad=0$, the radon flux is zero at the bottom of each soil zone and $\mathrm{C}(\mathrm{z})$ and $\mathrm{J}(\mathrm{z})$, the radon concentration and flux, respectively, are continuous across interfaces in the ground. 
Table B.5-7

Method for Calculating the Concentration of Radon in Outdoor and Indoor Air (Page 2 of 3 )

\section{Outdoor Air Concentration of Radon}

The average annual radon concentration outdoors is calculated as:

where:

$$
\mathrm{C}_{\mathrm{o}}=\left(\mathrm{J}_{\mathrm{o}} \mathrm{F}_{\mathrm{ao}} / \lambda \mathrm{H}_{\mathrm{o}}\right)\{1-\exp -\{\lambda \mathrm{X} / 2 \mathrm{U}\}\}
$$

$\mathrm{C}_{\mathrm{o}}=$ annual average concentration of radon outdoors $\left(\mathrm{pCi} / \mathrm{m}^{3}\right)$;

$\mathrm{J}_{\mathrm{o}}=$ radon flux at the soil surface outdoors $\left(\left[\mathrm{pCi} / \mathrm{m}^{2}\right] / \mathrm{s}\right)$;

$\mathrm{H}_{\mathrm{o}}=$ height into which plume is uniformly mixed $(2 \mathrm{~m})$;

$\mathrm{F}_{\mathrm{ao}}=$ outdoor area factor (dimensionless);

$A=$ area of the DPF $\left(3,716 \mathrm{~m}^{2}\right)$

$X=(A)^{1 / 2}=$ effective length of the contaminated area $(60 \mathrm{~m})$;

$U=$ annual average wind speed (3.1 m/s from DOE/NV, 1996a); and

$F_{\text {ao }}=A / 100,0 \leq A \geq 100 \mathrm{~m}^{2}$

$=1.0$ if $A \geq 100 \mathrm{~m}^{2}$.

As a constraint for the ratio $\mathrm{C}_{0}$ to $\mathrm{J}_{0}$, it is assumed in RESRAD that:

$$
\begin{aligned}
& \left(C_{0} / J_{0}\right)_{R n-222} \leq 500 \mathrm{~s} / \mathrm{m} \\
& \left(C_{0} / J_{0}\right)_{\text {Rn-220 }} \leq 10 \mathrm{~s} / \mathrm{m}
\end{aligned}
$$

\section{Indoor Air}

Assuming a steady-state, single-compartment model, the mass balance of radon inside a building can be expressed as:

where:

$$
d C_{i} / d t=\left(J_{i} A_{i} F_{a i} / V\right)-(\lambda+v) C_{i}+v C_{o}=0
$$

$\mathrm{C}_{\mathrm{i}}=$ radon concentration indoors $\left(\mathrm{pCi} / \mathrm{m}^{3}\right)$;

$J_{i}=$ radon flux from the floor built on the DPF $\left(\mathrm{pCi} / \mathrm{m}^{2} \mathrm{~s}\right)$;

$A_{i}=$ interior surface area of the building floor $\left(100 \mathrm{~m}^{2}\right)$;

$\mathrm{F}_{\mathrm{ai}}=$ indoor area factor (dimensionless);

$\mathrm{V}^{\mathrm{ai}}=$ interior volume of the building $\left(\mathrm{m}^{3}\right)$;

$\Lambda=$ decay constant of radon $\left(2.098 \times b^{10^{-6}}\right.$ per second for $\left.{ }^{222} \mathrm{Rn}\right)$; and

$v=$ ventilation rate of the house $(1 / \mathrm{s})^{b}$. 


\section{Table B.5-7}

Method for Calculating the Concentration of Radon in Outdoor and Indoor Air (Page 3 of 3 )

For the Decontamination Pond Facility,

$$
F_{a i}=1+4 D_{h} /\left(A_{i}\right)^{1 / 2}
$$

where:
$A=$ area of contamination at the DPF $\left(3,716 \mathrm{~m}^{2}\right)$;
$A_{i}=$ interior surface area of the building floor $\left(100 \mathrm{~m}^{2}\right)$; and
$D_{h}=$ depth of the foundation wall below and within the contaminated zone $(\mathrm{m})$.

The solution for Eq. 10 for the indoor radon concentration, $C_{i}$, can be written as:

$$
C_{i}=\left\{\left(J_{i} F_{a i} / H\right)+v C_{o}\right\} /(\lambda v)
$$

where:

$$
\mathrm{H}=\mathrm{V} / \mathrm{A}_{\mathrm{i}}
$$

${ }_{b}^{a}$ Picocurie(s) per square meter-second

1 per second 


\section{Table B.5-8 \\ Radon Dosimetry}

(Page 1 of 2)

Effective Dose Equivalent from radon and its decay products is calculated by RESRAD using the concept of the working level month (WLM):

where:

$$
\begin{gathered}
\text { WLM }=1.3 \times 10^{5} \mathrm{MeV} \text { of alpha energy released } \\
\mathrm{WLM}_{\mathrm{Rn}-222}=\left(1.03 \times 10^{-6} \mathrm{~A}\right)+\left(5.07 \times 10^{-6} \mathrm{~B}\right)+\left(3.73 \times 10^{-6} \mathrm{C}\right) \\
\mathrm{WLM}_{\mathrm{Rn}-220}=\left(9.48 \times 10^{-10} \mathrm{~A}^{\prime}\right)+\left(1.23 \times 10^{-4} \mathrm{~B}^{\prime}\right)+\left(1.17 \times 10^{-5} \mathrm{C}^{\prime}\right)
\end{gathered}
$$

$$
\begin{array}{lll}
\mathrm{WLM}_{\mathrm{Rn}-222} & =\text { WLM due to }{ }^{222} \mathrm{Rn} \text { and its decay products; } \\
\mathrm{A} & =\text { Concentration of }{ }^{218} \mathrm{Po}\left(\mathrm{pCi} / \mathrm{m}^{3}\right) ; \\
\mathrm{B} & =\text { Concentration of }{ }^{214} \mathrm{~Pb}\left(\mathrm{pCi} / \mathrm{m}^{3}\right) ; \text { and } \\
\mathrm{C} & \text { Concentration of }{ }^{214} \mathrm{Bi}\left(\mathrm{pCi} / \mathrm{m}^{3}\right)
\end{array}
$$

\section{Outdoor Concentration of Radon Progeny in Air}

Decay and ingrowth of radon decay products occurs during the transit time from soil to dose receptor. The transit time is calculated in RESRAD in the following way:

where:

$$
t=x /(2 U)
$$

$\mathrm{t}=$ transit time $(\mathrm{s})$;

$X=(A)^{1 / 2}=$ for the $\operatorname{DPF}(60.96 \mathrm{~m}) ;$ and

$U=$ annual mean wind speed at the DPF $(3.1 \mathrm{~m} / \mathrm{s})$.

where:

$$
\mathrm{C}_{\mathrm{o}(\mathrm{n})}=\left(\mathrm{J}_{\mathrm{o}} \mathrm{F}_{\mathrm{ao}} / \mathrm{H}_{\mathrm{o}}\right) \sum_{\mathrm{i}=1}^{\mathrm{n}} \mathrm{A}_{(\mathrm{i}, \mathrm{n})}\left(\left\{1-\left[\exp ^{-}(\lambda \mathrm{ix} / 2 \mathrm{U})\right]\right\} / \lambda_{\mathrm{i}}\right)
$$

$\mathrm{C}_{\mathrm{o}(\mathrm{n})}=$ nth radon progeny concentration outdoors $\left(\mathrm{pCi} / \mathrm{m}^{3}\right)$;

$\lambda_{\mathrm{i}} \quad=$ ith radon progeny decay constant (fraction decaying/s);

$\mathrm{A}_{(\mathrm{i}, \mathrm{n})}=\left(\lambda_{2} \ldots \lambda_{\mathrm{n}}\right) /\left(\lambda_{1}-\lambda_{\mathrm{i}}\right) \ldots\left(\lambda_{\mathrm{n}}-\lambda_{\mathrm{i}}\right), \mathrm{n} \neq \mathrm{i}$; and

$A_{(1,1)}=1$.

RESRAD limits the outdoor concentration of ${ }^{220} \mathrm{Rn}$ decay products by the following constraints:

$$
\mathrm{C}_{\mathrm{o}(\mathrm{PB}-212)} / \mathrm{C}_{\mathrm{o}(\mathrm{Rn}-220)} \leq 0.015 \text {, and } \mathrm{C}_{\mathrm{o}(\mathrm{Bi}-212)} / \mathrm{C}_{\mathrm{o}(\mathrm{Rn}-220)} \leq 0.015
$$




\section{Table B.5-8 \\ Radon Dosimetry}

(Page 2 of 2)

\section{Indoor Radon Decay Product Concentration}

The indoor radon air concentration is calculated by a mass balance equation. The time variation of the concentration of any element of the decay series is equal to the sum of the ingrowth rate from the decay of its immediate predecessor, plus the inflow rate from the outdoor concentration due to the ventilation, minus its decay rate and the outflow rate due to the ventilation. Under steady-state conditions, the mass balance equation can be solved for $\mathrm{C}_{\mathrm{i}(\mathrm{n})}$ as:

where:

$$
C_{i(n)}=\left[\lambda_{n} C_{i(n-1)}+v C_{o(n)}\right] /\left(\lambda_{n}+v\right) \quad n=2,3,4
$$

$$
\begin{array}{ll}
\mathrm{C}_{\mathrm{i}(\mathrm{n})} & =\text { concentration of radon progeny }(\mathrm{n}) \text { indoors }\left(\mathrm{pCi} / \mathrm{m}^{3}\right) ; \\
\mathrm{C}_{\mathrm{o}(\mathrm{n})} & =\text { concentration of radon progeny }(\mathrm{n}) \text { outdoors }\left(\mathrm{pCi} / \mathrm{m}^{3}\right) ; \\
\lambda_{\mathrm{n}} & =\text { the decay constant for radon progeny }(\mathrm{n})(\text { fraction per second); and } \\
\mathrm{V} & =\text { the ventilation rate indoors (fraction of air exchanged } / \mathrm{h}) .
\end{array}
$$

Equations 13 and 14 are used to convert $C_{i(n)}$ to WLM.

\section{Radon Dosimetry}

Radon decay products are retained on the mucus layer covering the bronchial and pulmonary regions of the lung. The cells below the mucus layer are exposed to the emitted radiation. In RESRAD the dose from radon and its progeny is calculated using the WLM. RESRAD uses the following conversion factors to calculate effective dose assessment from WLM

\begin{tabular}{|l|c|c|}
\hline Exposure Scenario & $\begin{array}{c}\text { Dose Conversion Factor for } \\
\mathbf{R n - 2 2 2} \\
(\mathrm{mrem} / \mathrm{WLM})\end{array}$ & $\begin{array}{c}\text { Dose Conversion Factor for } \\
\mathbf{R n - 2 2 0} \\
(\mathrm{mrem} / \mathrm{WLM})\end{array}$ \\
\hline Indoors & 760 & 150 \\
\hline Outdoors & 570 & 250 \\
\hline
\end{tabular}


In calculating the dose from the intake of radionuclides into the body, the occurrence of radioactive decay products is considered by RESRAD. When an atom undergoes radioactive decay, the new atom formed may also be radioactive and, thus, contribute to the dose. Although these decay products may be treated as independent radionuclides in external exposures, they must be considered in conjunction with the parent in the evaluation of radionuclides inhaled or ingested because their distribution among the organs of the body depends on the metabolism of their parent (ICRP, 1979 - 1982). Thus, the contributions to dose from decay products formed within the body are included in the DCF for any radionuclide with radioactive decay products. Additional details on the ICRP guidance for calculating the removal of radionuclides in the body via metabolic processes and radioactive decay are found in Appendices A through $\mathrm{C}$ of the RESRAD User's Manual (Yu et al., 1993a). 


\section{B.6.0 Dose Assessment Summary}

The doses to the radiological worker and the industrial worker for the No Action and Engineered Cap Alternatives are listed in Tables B.6-1 through B.6-4. The tables list the following:

- Radionuclides contributing to greater than 0.5 percent of the TEDE by the four exposure pathways

- A fraction of the TEDE from each radionuclide that contributed greater than 0.5 percent of the TEDE

- The TEDE for four time periods: 0 to 10 years, 10 to 30 years, 30 to 100 years, and greater than 100 years

For the No Action Alternative and Engineered Cap Alternative, the TEDE to both the radiological worker and the industrial worker never exceeds the dose limit established in DOE Order 5400.5 of $100 \mathrm{mrem} / \mathrm{yr}$ for protection to members of the public (DOE, 1993) . The concentration of radium in the ground does not exceed the limits in DOE Order 5400.5 and 40 CFR 192 of 5 pCi/g over background in the top $15 \mathrm{~cm}(.05 \mathrm{ft})$ of soil and $15 \mathrm{pCi} / \mathrm{g}$ in each succeeding $15 \mathrm{~cm}$ (0.5 ft) layer of soil (DOE, 1993; CFR, 1996b). No structures are located on the DPF, so the limits established in DOE Order 5400.5 for airborne radon decay product concentration, external gamma radiation levels, and surface contamination do not apply. Nevertheless, calculations were performed to determine the radon decay product concentration and external gamma radiation exposure rates in a hypothetical building located on the DPF.

The radon decay product concentration limit established in DOE Order 5400.5 is 0.2 Working Levels (WL) (DOE, 1993). The radon decay product concentration does not exceed 0.2 WL for either the No Action or Engineering Cap Alternatives, even during the years of maximum radon decay product concentration. The external gamma radiation exposure rate limit established in DOE Order 5400.5 is $20 \mu \mathrm{R} / \mathrm{h}$ (DOE, 1993). This limit is exceeded for the No Action Alternative for 20-years post-closure.

The TEDE to the radiological worker never exceeds $1 \mathrm{mrem} / \mathrm{yr}$. This is significantly less than the $5,000 \mathrm{mrem} / \mathrm{yr}$ legal limit or the $500 \mathrm{mrem} / \mathrm{yr}$ guidance level recommended in the NTS/Yucca Mountain Radiological Control Manual (DOE/NV, 1996c). 
Table B.6-1

Dose Summary for the Hypothetical Radiation Worker at the Area 6 Decon Pond: No Action Alternatives

\begin{tabular}{|c|c|c|c|c|}
\hline \multirow{2}{*}{$\begin{array}{l}\text { EXPOSURE PATHWAY } \\
\text { External Dose }\end{array}$} & \multicolumn{4}{|c|}{$\begin{array}{c}\text { Percent of Total Effective Dose Equivalent } \\
\text { Years Post-Closure }\end{array}$} \\
\hline & 0 to 10 years & 10 to 30 years & 30 to 100 years & $>100$ years \\
\hline Cobalt- 60 & $90-74$ & $74-23$ & $23-0$ & 0 \\
\hline Cesium-137 + D & $9-23$ & $23-66$ & $66-35$ & $35-3$ \\
\hline Radium-226 + D & 0 & 0 & $0-21$ & $21-48$ \\
\hline Thorium-232 + D & $<1$ & $<1$ & $<1-13$ & $13-32$ \\
\hline Percentage subtotal & $99-98$ & $97-89$ & $89-69$ & $69-83$ \\
\hline \multicolumn{5}{|l|}{ Radon Decay Products } \\
\hline Radium-226 + D & $<1$ & $<1$ & $<1$ & $<1$ \\
\hline Plutonium-238 + D & 0 & 0 & 0 & 0 \\
\hline Plutonium-239/240 + D & 0 & 0 & 0 & 0 \\
\hline \multicolumn{5}{|l|}{ Dust Inhalation } \\
\hline Plutonium-239/240 + D & $0-1$ & $1-6$ & $6-18$ & $18-8$ \\
\hline Americium-241 + D & $0-<1$ & $<1-3$ & $3-6$ & $8-1$ \\
\hline Thorium-232 + D & 0 & $<1$ & $<1-2$ & $0-5$ \\
\hline Percentage subtotal & 1 & $1-9$ & $9-26$ & $26-14$ \\
\hline \multicolumn{5}{|l|}{ Soil Ingestion } \\
\hline All radionuclides & 0 & 0 & $0-3$ & 3 \\
\hline TEDE (mrem/yr) & $0.92-0.30$ & $0.30-0.077$ & $0.077-.041$ & $0.03-0.064$ \\
\hline
\end{tabular}

Isotope + D means the percentage of the TEDE includes the contribution from all of the radionnuclide's decay products

TEDE = Total Effective Dose Equivalent 
Table B.6-2

Dose Summary for the Hypothetical Radiation Worker at the Area 6 Decon Pond: Engineered Cap Alternatives

\begin{tabular}{|c|c|c|c|c|}
\hline \multirow{2}{*}{$\begin{array}{l}\text { EXPOSURE PATHWAY } \\
\text { External Dose } \\
\end{array}$} & \multicolumn{4}{|c|}{$\begin{array}{c}\text { Percent of Total Effective Dose Equivalent } \\
\text { Years Post-Closure }\end{array}$} \\
\hline & 0 to 10 years & 10 to 30 years & 30 to 100 years & $>100$ years \\
\hline Cobalt-60 & $99-96$ & $96-41$ & $41-0$ & 0 \\
\hline Cesium-137 + D & $1-4$ & $4-16$ & $16-2$ & $2-0$ \\
\hline Radium-226 + D & 0 & $0-8$ & $8-28$ & $28-35$ \\
\hline Thorium-232 + D & 0 & $0-11$ & $11-37$ & $37-51$ \\
\hline Percentage subtotal & 100 & $100-76$ & $76-67$ & $67-86$ \\
\hline \multicolumn{5}{|l|}{$\begin{array}{l}\text { Inhalation of } \\
\text { Radon Decay Products }\end{array}$} \\
\hline Radium-226 + D & 0 & $0-24$ & $24-33$ & $33-0$ \\
\hline Plutonium-238 + D & 0 & 0 & 0 & 0 \\
\hline Plutonium-239/240 + D & 0 & 0 & 0 & 0 \\
\hline \multicolumn{5}{|l|}{ Dust Inhalation } \\
\hline Plutonium-239/240 + D & 0 & 0 & 0 & $0-4$ \\
\hline Americium-241 + D & 0 & 0 & 0 & 0 \\
\hline Thorium-232 + D & 0 & 0 & 0 & $0-8$ \\
\hline All others & 0 & 0 & 0 & 0 \\
\hline \multicolumn{5}{|l|}{ Soil Ingestion } \\
\hline All radionuclides & 0 & 0 & 0 & $0-1$ \\
\hline TEDE (mrem/yr) & $<0.0001$ & $<0.0001$ & $<0.0001$ & $0-0.032$ \\
\hline
\end{tabular}

Isotope $+\mathrm{D}$ means the percentage of the TEDE includes the contribution from all of the radionuclide's decay products.

TEDE $=$ Total Effective Dose Equivalent 
Table B.6-3

Dose Summary for the Hypothetical Industrial Worker at the Area 6 Decon Pond: No Action Alternatives

\begin{tabular}{|c|c|c|c|c|}
\hline \multirow{2}{*}{$\begin{array}{l}\text { EXPOSURE PATHWAY } \\
\text { External Dose } \\
\end{array}$} & \multicolumn{4}{|c|}{$\begin{array}{c}\text { Percent of Total Effective Dose Equivalent } \\
\text { Years Post-Closure } \\
\end{array}$} \\
\hline & 0 to 10 Years & 10 to 30 Years & 30 to 100 Years & $>100$ Years \\
\hline Cobalt-60 & NA & $45-14$ & $14-0$ & 0 \\
\hline Cesium-137 + D & NA & $15-38$ & 38 & $38-0$ \\
\hline Radium-226 + D & NA & 2 & $2-4$ & $4-12$ \\
\hline Thorium-232 + D & NA & $0-1$ & $1-3$ & $3-9$ \\
\hline Percentage subtotal & NA & $62-55$ & $55-45$ & $45-21$ \\
\hline \multicolumn{5}{|l|}{$\begin{array}{l}\text { Inhalation of } \\
\text { Radon Decay Products }\end{array}$} \\
\hline Radium-226 + D & NA & $38-43$ & $43-42$ & $42-77$ \\
\hline Plutonium-238 + D & NA & 0 & 0 & 0 \\
\hline Plutonium-239/240 + D & NA & 0 & 0 & 0 \\
\hline \multicolumn{5}{|l|}{ Dust Inhalation } \\
\hline Plutonium-239/240 + D & NA & $0-1$ & $1-6$ & $6-1$ \\
\hline Americium-241 + D & NA & 0 & $0-2$ & $2-0$ \\
\hline Thorium-232 + D & NA & 0 & 0 & 0 \\
\hline All others & NA & 0 & 0 & 0 \\
\hline \multicolumn{5}{|l|}{ Soil Ingestion } \\
\hline All radionuclides & NA & 1 & $1-5$ & $5-0$ \\
\hline TEDE (mrem/yr) & NA & $86.7-49.3$ & $49.3-46.6$ & $46.6-69.4$ \\
\hline
\end{tabular}

Isotope + D means the percentage of the TEDE includes the contribution from all of the radiological decay products.

TEDE $=$ Total Effective Dose Equivalent

NA $=$ Not applicable, the Industrial Worker is not expected to be on site $<10 \mathrm{yrs}$ post-closure. 
Table B.6-4

Dose Summary for the Hypothetical Industrial Worker at the Area 6 Decon Pond: Engineered Cap Alternatives

\begin{tabular}{|c|c|c|c|c|}
\hline \multirow{2}{*}{$\begin{array}{l}\text { EXPOSURE PATHWAY } \\
\text { External Dose } \\
\end{array}$} & \multicolumn{4}{|c|}{$\begin{array}{c}\text { Percent of Total Effective Dose Equivalent } \\
\text { Years Post-Closure } \\
\end{array}$} \\
\hline & 0 to 10 Years & 10 to 30 Years & 30 to 100 Years & $>100$ Years \\
\hline Cobalt-60 & NA & 0 & 0 & 0 \\
\hline Cesium-137 + D & NA & 0 & 0 & 0 \\
\hline Radium-226 + D & NA & 0 & 0 & $0-12$ \\
\hline Thorium-232 + D & NA & 0 & 0 & $0-16$ \\
\hline All others & NA & 0 & 0 & 0 \\
\hline \multicolumn{5}{|l|}{$\begin{array}{l}\text { Inhalation of } \\
\text { Radon Decay Products }\end{array}$} \\
\hline Radium-226 + D & NA & 100 & 100 & $100-70$ \\
\hline Plutonium-238 + D & NA & 0 & 0 & 0 \\
\hline Plutonium-239/240 + D & NA & 0 & 0 & 0 \\
\hline \multicolumn{5}{|l|}{ Dust Inhalation } \\
\hline Plutonium-239/240 + D & NA & 0 & 0 & 1 \\
\hline Americium-241 + D & NA & 0 & 0 & 0 \\
\hline Thorium-232 + D & NA & 0 & 0 & 0 \\
\hline All others & NA & 0 & 0 & 0 \\
\hline \multicolumn{5}{|l|}{ Soil Ingestion } \\
\hline All radionuclides & NA & 0 & 0 & 1 \\
\hline TEDE (mrem/yr) & NA & $15.8-16.0$ & $16.0-16.4$ & $16.4-42.7$ \\
\hline
\end{tabular}

Isotope + D means the percentage of the TEDE includes the contribution from all of the radionuclide's decay products.

TEDE $=$ Total Effective Dose Equivalent

NA $=$ not applicable, the Industrial Worker is not expected to be on site $<10$ yrs post-closure. 
Under the No Action Alternative, the TEDE to the industrial worker never exceeds the $100 \mathrm{mrem} / \mathrm{yr}$ limit established in DOE Order 5400.5 (DOE, 1993). The maximum TEDE is $86.7 \mathrm{mrem} / \mathrm{yr}$ at 10 years post closure. The TEDE drops to $46.6 \mathrm{mrem} / \mathrm{yr}$ after 100 years and continues to drop for several hundred years. After 300 years, the TEDE rises to a peak of $69.4 \mathrm{mrem} / \mathrm{yr}$ and then drops continuously. The annual dose rate is dominated by the radionuclides in the top $0.6 \mathrm{~m}(2 \mathrm{ft})$ of soil. Greater than 99 percent of the dose to the industrial

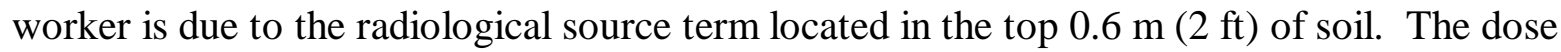
from external exposure contributes 62 to 55 percent of the dose from ten to thirty years postclosure under the No Action Alternative. In subsequent years, the external dose drops at rates comparable to the decay rate of cobalt-60 and cesium-137. By 100 years post-closure, the external exposure pathway is still contributing 45 percent of the dose. Inhalation of radon decay products contributes 38 to 43 percent of the dose from 30 to >100 years subsequent to closure. Subsequent to that, the dose fraction from radium-226 continues to climb and reaches a maximum of 84 percent of the dose after several hundred years.

The dose to the industrial worker under the Engineered Cap Alternative is approximately 25 percent of the dose from the No Action Alternative. The dose is approximately $16 \mathrm{mrem} / \mathrm{yr}$ for the first hundred years post-closure. The only exposure pathway that contributes to the dose is the inhalation of radon decay products. 


\section{B.7.0 Toxicity Assessment}

The purpose of the toxicity assessment is to weigh available evidence regarding the potential for particular contaminants to cause adverse effects in exposed individuals and to provide, where possible, an estimate of the relationship between the extent of exposure to a contaminant and the increased likelihood and severity of adverse effects.

The detrimental effects of radiation, such as carcinogenesis, are the most extensively studied health effects of any toxic agent. There are two types of effects from dose due to the exposure of individuals to radiation. The first type is known as a nonstochastic effect. Nonstochastic effects are those whose probability of occurrence is zero until the dose reaches a specific threshold. At doses greater than the threshold, the probability of occurrence is one. For nonstochastic effects the severity of the effect increases proportionally with the dose, once the dose is greater than the threshold. Examples of stochastic effects are cataracts, sterility in males, and the death of bone marrow cells. The dose thresholds for nonstochastic effects are thousands of times greater than the dose limits established for protection of the public. The thresholds for nonstochastic effects range from 200,000 mrem to 1,000,000 mrem. The lifetime doses received by the hypothetical dose receptors at the DPF under the No Action and Engineering Cap Alternatives do not exceed 1,900 mrem. Therefore, there will be no nonstochastic effects.

The second type of effect from radiation dose to biological tissue is the stochastic effect. Stochastic effects are those whose probability of occurrence is proportional to dose at high doses and high dose rates. The severity of a stochastic effect is not dependent on dose. Examples of stochastic effects are cancer and genetic mutations. Cancer rates above background have not been observed in humans at dose rates less than 300 times the maximum dose rate allowed by the DOE for members of the public. Increases in cancer rates have not been observed in human populations except for populations receiving greater than 30,000 mrem each at very high dose rates. An increase in the rate of genetic effects has never been observed in humans due to radiation dose. Increases in other stochastic effects have not been observed in human or animal populations at doses less than about 10,000 mrem. Because the maximum lifetime dose to the radiological worker and industrial worker will not exceed 1,900 mrem over 30 years, the probability of a stochastic effect is zero. 


\section{B.8.0 Risk Characterization}

The primary risk from radiation dose to members of the public is carcinogenesis. An extensive body of literature exists on radiation exposure to humans and animals demonstrating that thresholds of approximately 30,000 mrem exist for carcinogenesis in human beings. Below that level of dose, there is no increase in the cancer rate among humans or animal populations.

Despite the scientific literature to the contrary, the EPA has adopted the linear nonthreshold theory for extrapolating cancer rate data for populations exposed at high doses and high dose rates to populations receiving low doses and low dose rates. The linear nonthreshold theory states that no dose threshold exists for stochastic effects, that there is a positive probability for a stochastic effect at any dose above zero, and that probability increases linearly above zero dose. The linear non-threshold theory was developed as a risk management tool early on in the nuclear industry to ensure that workers who could potentially receive high doses and high dose rates were protected from stochastic effects. This model has been disproved repeatedly in epidemiological studies involving radiation background and in radiation worker studies (ICRP, 1991b). The Japanese Atomic Bomb Survivor data and nuclear shipyard worker data also refute the model in the low-dose region (Shimizu et al., 1993; DOE, 1991).

The National Research Council in their BEIR V report stated,'the possibility that there may be no risks from exposures comparable to external natural background cannot be ruled out. At such low doses and dose rates, it must be acknowledged that the lower limit of the range of uncertainty in the risk estimates extends to zero" (NRC, 1990). A similar statement was also made by the ICRP. The Commission stated that even though the study population of the nuclear bomb survivors is large (about 80,000), excess effects below 20,000 mrem are not significant at the 95 percent level (ICRP, 1991).

The Health Physics Society is an international professional organization dedicated to the development, dissemination, and application of both the scientific knowledge of, and the practical means for, radiation protection. In their position statement on risk assessment, they recommended "assessments of radiological health risk be limited to dose estimates near and above 10,000 mrem. Below this level, only dose is credible and statements of associated risk are more speculative than credible" (HPS, 1995). 
The EPA has adopted the linear nonthreshold for predicting the probability of stochastic effects from radiation dose for all doses and dose rates received by individuals.

The nominal probability coefficients for stochastic effects used by the EPA and others (ICRP, 1991) for the public are stated below:

- Probability of a fatal cancer is $5 \times 10^{-7}$ per mrem

- Probability of a non-fatal cancer is $1 \times 10^{-7}$ per mrem

- Probability of a severe hereditary effect is $1.3 \times 10^{-7}$ per mrem

A difficulty with applying these coefficients to low dose rates is that their total standard error ranges on the order of $10^{-6}$ to $10^{-5}$ (Seiler and Alvarez, 1995). The uncertainty in the calculated risk exceeds the calculated risk by at least one order of magnitude.

Under both the No Action and Engineering Cap Alternatives, the calculated risk to the radiological worker for fatal cancer, nonfatal cancer, and severe hereditary effects is less than $5 \times 10^{-6}$. This risk is less than the $10^{-4}$ value recommended by the EPA for fatal and nonfatal cancers. For the industrial worker under the No Action Alternative, the probabilities of fatal cancer, nonfatal cancer, and severe hereditary effects are $9.5 \times 10^{-4}, 1.9 \times 10^{-4}$, and $2.5 \times 10^{-4}$, respectively. All of these values exceed the value recommended by the EPA for requiring remediation of Superfund sites. The risks of a fatal cancer, nonfatal cancer, and severe hereditary effects for the industrial worker under the Engineered Cap Alternative are $2 \times 10^{-4}, 3.9 \times 10^{-5}$, and $5.1 \times 10^{-5}$. Since there is significant error in all of the calculated risk, none of these calculated values are significantly different than zero. 


\section{B.9.0 Uncertainties in the Assessment}

Uncertainties in this assessment exist due to the uncertainties in the radiological source term, the parameter values chosen to describe and model the DPF site, the models used in calculating the transport of radionuclides through the environment, the dose conversion factors, and the risk factors.

The assumptions used in this assessment for determining the background concentration of radionuclides in soil, environmental sampling and analysis, fate and transport modeling of the DPF, the radon inhalation model, and cancer risk estimates are summarized in Table B.9-1.

None of the parameters used in this assessment are considered to have a high potential for underestimating the TEDE and resulting risk. Conservative values were used in each case, typically values that were well beyond the 50 percentile and often beyond the 90 percentile.

Four parameters are considered to have a high potential for overestimating the TEDE and resulting risk. These are the concentration of radium-226 in soil, the fraction of time the industrial worker spends on site, the effective radon diffusion coefficient, and the cancer risk estimates.

The uncertainties in the concentration of radium-226 are discussed in Section B.2.0. The concentration of radium-226 is not statistically different at the 95 percent confidence level than background. This difference from background could be due to the use of gamma spectroscopy for measuring the radium-226 concentration in soil. One standard deviation in the concentration measurement for radium-226 was approximately 30 percent of the mean. The assumptions made regarding the concentration of radium-226 in soil have a significant effect on the calculated dose and resultant risk. The external exposure dose from radium-226 and the inhalation dose from radon gas decay products contributed from 40 to 100 percent of the dose for the two exposure scenarios analyzed for the DPF. The radium-226 concentration in soil is more likely overestimated rather than underestimated. To reduce the uncertainty in the radium-226 concentration, more precise measurement methods should be used. Two types of measurements that will give greater precision are alpha spectroscopy and radon gas emanation measurements. 
Table B.9-1

Uncertainties in the Dose and Risk Assessment

(Page 1 of 2)

\begin{tabular}{|c|c|c|}
\hline \multirow[b]{2}{*}{ ASSUMPTIONS } & \multicolumn{2}{|c|}{ Effect on Dose and Risk } \\
\hline & $\begin{array}{c}\text { Potential } \\
\text { Magnitude for } \\
\text { Underestimating } \\
\text { TEDE } \\
\end{array}$ & $\begin{array}{c}\text { Potential } \\
\text { Magnitude for } \\
\text { Overestimating } \\
\text { TEDE } \\
\end{array}$ \\
\hline $\begin{array}{l}\text { Background Concentrations } \\
\text { Hundreds of large volume soil samples were taken at } \\
\text { dozens of background locations in Nevada }\end{array}$ & Very low & Low \\
\hline $\begin{array}{l}\text { Environmental Sampling and Analysis } \\
\text { Over } 100 \text { soil samples were taken and analyzed for } \\
\text { radionuclides. Samples were taken from depths ranging } \\
\text { from } 6 \text { inches to }>20 \mathrm{ft} \text {. } \\
\text { Systematic or random errors in the gamma analysis for } \\
\text { Radium-226 may have yielded erroneous data. }\end{array}$ & Low & $\begin{array}{l}\text { Very low } \\
\text { High }\end{array}$ \\
\hline $\begin{array}{l}\text { Fate and Transport Modeling } \\
\text { Mass Loading } \\
\text { Fraction of time on-site: } \\
\text { Radiological worker } \\
\text { Industrial worker }\end{array}$ & Very low & Low \\
\hline Inhalation rate & Very low & Low \\
\hline Soil density & Very low & Very low \\
\hline Dose conversion factors & Very low & Medium \\
\hline Shielding factors & Very low & Medium \\
\hline
\end{tabular}


Table B.9-1

Uncertainties in the Dose and Risk Assessment (Page 2 of 2)

\begin{tabular}{|c|c|c|}
\hline \multirow[b]{2}{*}{ ASSUMPTIONS } & \multicolumn{2}{|c|}{ Effect on Dose and Risk } \\
\hline & $\begin{array}{c}\text { Potential } \\
\text { Magnitude for } \\
\text { Underestimating } \\
\text { TEDE } \\
\end{array}$ & $\begin{array}{c}\text { Potential } \\
\text { Magnitude for } \\
\text { Overestimating } \\
\text { TEDE } \\
\end{array}$ \\
\hline$\frac{\text { Radon Inhalation Model }}{\text { Total Porosity }}$ & Low & Low \\
\hline Effective porosity & Medium & Very low \\
\hline Effective radon diffusion coefficient & Very low & High \\
\hline Radon emanation coefficient & Low & Low \\
\hline$\frac{\text { Cancer Risk Estimates }}{\text { Linear non-threshold assumption }}$ & Very low & Very high \\
\hline
\end{tabular}

Effects marked as "very low" may affect estimates of dose and risk by less than a factor of two. Effects marked as "low" may affect estimates of dose and risk by less than one order of magnitude. Effects marked as "medium" may affect estimates of dose and risk by greater than one order of magnitude. Effects marked as "high" may affect estimates of dose and risk by greater than two orders of magnitude. Effects marked as "very high" may affect estimates of dose and risk by greater than four orders of magnitude.

TEDE $=$ Total Effective Dose Equivalent 
The second parameter value having a high potential for overestimating dose and the resulting risk is the time the industrial worker is expected to be on site. The industrial worker is expected to be on the DPF for 40 hours per week, 50 weeks per year, for 30 years. There is a low probability that anyone would ever build on the DPF because it is located on a dry lake bed that floods after local precipitation events, and there is no infrastructure available. Industrial activities would more likely take place where buildings, electricity, roads, and telephones already exist. In addition, the 30-year time period for a worker to spend at one job location is extremely conservative. According to data from the Bureau of Labor Statistics (1987), 25 years is the upper 95th percentile of the distribution for number of years spent at a specific job. The 50th percentile is 4 years. The dose and risk to the industrial worker are directly proportional to the time spent on the DPF. If the worker is not there, there is no dose or risk. The dose from an exposure of four years would be only 13 percent of that from 30 years. This reduces the dose and risk for the industrial worker under the no action alternative to less than the recommended risk for cleanup by the EPA (1989).

The effective radon diffusion coefficient has a high potential for overestimating dose and the resulting risk from radium-226. The value chosen for this assessment is the RESRAD default value of $2.00 \times 10^{-6}$ meters per second $(\mathrm{m} / \mathrm{s})$. The values for effective radon diffusion coefficient range from $6 \times 10-10 \mathrm{~m} / \mathrm{s}$ to as high as $7 \times 10^{-6} \mathrm{~m} / \mathrm{s}$ (Yu et al., 1993a). The higher the effective radon diffusion coefficient, the greater the calculated dose and resultant risk. The value used in this assessment is greater than the 90 percentile of the range.

The cancer risk probability coefficients have a high potential for overestimating the risk from the dose received by the radiological worker and industrial worker. As stated in Section B.8.0, no scientific basis has been identified for assuming that anyone receiving low doses at low dose rates would acquire a fatal or nonfatal cancer. The adoption of the linear nonthreshold theory in predicting cancer risk at low doses and low dose rates has no basis in epidemiology or laboratory research.

The dose and risk assessment performed demonstrates that for the exposure scenarios analyzed, the radiological worker and industrial worker, the doses under both the No Action and Engineered Cap do not exceed the requirements under DOE Order 5400.5 (DOE, 1993). The risks to the industrial worker under the No Action Alternative could exceed the recommended guidance of the EPA (1989). 


\section{B.10.0 References}

Atlan-Tech. 1992. Environmental Monitoring Report for the Proposed Ward Valley California LLRW Facility. Rosewall, GA: Atlan-Tech Inc.

Bureau of Labor Statistics. 1987. Most Occupational Exposures are Voluntary. Washington DC: U.S. Department of Labor.

CFR, see Code of Federal Regulations.

Code of Federal Regulations. 1996a. National Primary Drinking Water Act, 40 CFR 141. Washington, DC: U.S. Government Printing Office.

Code of Federal Regulations. 1996b. 40 CFR Part 192, "Health and Environmental Protection Standards for Uranium and Thorium Mill Tailings.” Washington, DC: U.S. Government Printing Office.

Chen, S.Y. 1991. "Calculation of Effective Dose Equivalent Responses for External Exposure from Residual Photon Emitters in Soil.” In Health Physics, 60:411-426. New York, NY.

DOE, see U.S. Department of Energy.

DOE/NV, see U.S. Department of Energy, Nevada Operations Office.

DRI, see Desert Research Institute.

Desert Research Institute. 1988. CERCLA Preliminary Assessment of DOE's Nevada Operations Office Nuclear Weapons Testing Areas, Vol. 1. Las Vegas, NV: Desert Research Institute Water Resource Center.

Environmental Statutes. 1988. Federal Clean Air Act. Rockville, Md: Government Institutes, Inc.

ES, see Environmental Statutes

Eve, I.S. 1966. "A Review of the Physiology of the Gastrointestinal Tract in Relation to Radiation Doses from Radioactive Material." In Health Physics 12(2):131-161. New York, NY: Pergamon Press.

Gilbert, T.L., et al. 1989. A Manual for Implementing Residual Radioactive Material Guidelines: A Supplement to the U.S. Department of Energy Guidelines for Residual Radioactive Material at FUSRAP and SFMP Sites, ANL/ES-160, DOE/CH/8901. Prepared for U.S. Department of Energy: Argonne, IL: Argonne National Laboratory. 
Health Physics Society. 1995. "Health Physics Society Position Statement on Risk Assessment." In Radiation Professionals Directory Handbook of 1996-1997:232-233. McLean, VA.

Healy, J.W. 1977. An Examination of the Pathways from Soil to Man for Plutonium, LA-6741-MS. Los Alamos, NM: Los Alamos Scientific Laboratory.

ICRP, see International Commission on Radiological Protection.

International Commission on Radiological Protection. 1966. "Deposition and Retention Models for Internal Dosimetry of the Human Respiratory Tract." In Health Physics 12:173. New York, NY: Pergamon Press.

International Commission on Radiological Protection. 1972. Alkaline Earth Metabolism in Adult Man, ICRP Publication 20. Oxford, United Kingdom: Pergamon Press.

International Commission on Radiological Protection. 1977. Recommendations of the International Commission on Radiological Protection, ICRP Publication 26, Annals of the ICRP, 1(2). New York, NY: Pergammon Press.

International Commission on Radiological Protection. 1978. Radionuclide Release into the Environment: Assessment of Doses to Man. A Report of Committee 4 of the International Commission on Radiological Protection, adopted by the Commission in October, 1978, ICRP Publication 29, Annals of the ICRP 2(2). New York, NY: Pergammon Press.

International Commission on Radiological Protection, 1979-1982. Limits for Intakes of Radionuclides by Workers. A report of Committee 2 of the International Commission on Radiological Protection, adopted by the Commission in July 1978, ICRP Publication 30, Part 1 (and Supplement), Part 2 (and Supplement), Part 3 (and Supplements A and B), and Index, Annals of the ICRP. New York, NY: Pergammon Press.

International Commission on Radiological Protection. 1991a. 1990 Recommendations of the International Commission on Radiological Protection, ICRP Publication 60, Annals of the ICRP, 21(1-3). New York, NY: Pergammon Press.

International Commission on Radiological Protection. 1991b. Annual Limits on Intake of Radionuclides by Workers Based on the 1990 Recommendations, ICRP Publication 61, Annals of the ICRP, 21(4). New York, NY: Pergammon Press.

Kocher, D.C. 1983. "Dose-Rate Conversion Factors for External Exposure to Photons and Electrons." In Health Physics 45(3):665. New York, NY: Pergamon Press.

Kocher, D.C., and A.L. Sjoreen. 1985. "Dose-Rate Conversion Factors for External Exposure to Photons Emitters in Soil." In Health Physics 48(2):193-205. New York, NY: Pergamon Press. 
Layton, D.W. 1993. "Metabolically Consistent Breathing Rates for Use in Dose Assessments." In Health Physics, 64:23-36. New York, NY: Pergamon Press.

McArthur, R.D. and F.L. Miller. 1989. Off-Site Radiation Exposure Review Project Phase II Soil Program, DOE/NV/10384-23. Las Vegas, NV: Desert Research Institute, University of Nevada.

National Council on Radiation Protection and Measurements. 1984. Radiological Assessment: Predicting the Transport, Bioaccumulation, and Uptake by Man of Radionuclides Released to the Environment, NCRP Report No. 76. Bethesda, MD.

NCRP, see National Council on Radiation Protection and Measurements.

NRC, see U.S. Nuclear Regulatory Commission.

NRC, see National Research Council.

National Research Council 1990. Health Effects of Exposure to Low Levels of Ionizing Radiation: BEIR V. Washington, DC: National Academy Press.

Shimizu, T., et al. 1993. "Dose-Response Analysis of Atomic Bomb Survivors Exposed to LowLevel Radiation.” In Health Physics Newsletter 21(1):1. New York, NY: Pergamon Press.

Shinn, J.H. 1986. A Summary of Plutonium Aerosol Studies: Resuspension at the Nevada Test Site, UCRL-90746. Livermore, CA: Lawrence Livermore National Laboratory.

Seiler, F.A., and J.L. Alvarez. 1994. "Definition of a Minimum Significant Risk." In Technology: Journal of the Franklin Institute, 331:83-95. Philadelphia, PA.

Till, J.E., and H.R. Meyer, Eds. 1983. Radiological Assessment. A Textbook on Environmental Dose Analysis, NUREG/CR-3332. Washington, DC: U.S. Nuclear Regulatory Commission.

U.S. Department of Energy. 1991. Health Effects of Low Level Radiation in Shipyard Workers, DOE Contract No. DE-ACO2-79EV10095, Final Report. Washington, DC.

U.S. Department of Energy. 1993. Radiation Protection of the Public and the Environment, DOE Order 5400.5. Washington, DC.

U.S. Department of Energy. 1996. Record of Decision: Environmental Impact Statement for the Nevada Test Site and Off-Site Locations in the State of Nevada. Washington, DC.

U.S. Department of Energy, Nevada Operations Office. 1996a. Annual Site Environmental Report, DOE/NV/11718037. Las Vegas, NV: Bechtel Nevada. 
U.S. Department of Energy, Nevada Operations Office. 1996b. Final Environmental Impact Statement for the Nevada Test Site and Off-/site Locations in the State of Nevada, DOE/EI2 0243. Las Vegas, NV.

U.S. Department of Energy, Nevada Operations Office. 1996c. NV/YMP Radiological Control Manual, DOE/NV/11718-079, Revision 2. Las Vegas, NV.

U.S. Department of Energy, Nevada Operations Office. 1996d. Resource Conservation and Recovery Act Industrial Site Environmental Restoration Site Characterization Plan Area 6 Decontamination Pond Facility, DOE/NV-438. Las Vegas, NV: IT Corporation.

U.S. Department of Energy, Nevada Operations Office. 1997. Resource Conservation and Recovery Act Industrial Site Environmental Restoration Characterization Report, Area 6 Decontamination Pond Facility. Las Vegas, NV: IT Corporation.

U.S. Environmental Protection Agency. 1989. Risk Assessment Guidance for Superfund, Vol. 1: Human Health Evaluation Manual, Part A, EPA/540/1-89/002. Washington, DC: Office of Emergency and Remedial Response.

U.S. Environmental Protection Agency. 1990. Supplemental Guidance to RAGS: Calculating the Concentration Term, Publication 9285.7-081. Washington, DC: Office of Solid Waste and Emergency Response.

U.S. Nuclear Regulatory Commission. 1977. Calculations of Annual Doses to Man from Routine Releases of Reactor Effluents for the Purpose of Evaluating Compliance with 10 CFR Part 50, Appendix I, Regulatory Guide 1.109, Rev. 1. Washington, DC.

Wilcox, B. Bechtel Nevada. 1997. "Cost Estimate Summary." Attachment to: Bechtel Nevada Memorandum from Allison Urbon to Mary Todd about cost estimates for closure options for CAU 92, Area 6 Decon Pond, 8 September.

Yu, C., et al. 1993a. Manual for Implementing Residual Radioactive Material Guidelines Using RESRAD, Version 5.0. ANL/EAD/LD-2. Argonne, IL: Argonne National Laboratory.

Yu, C., et al. 1993b. Data Collection Handbook to Support Modeling the Impacts of Radioactive Material in Soil, ANL/EAIS-8. Argonne, IL: Argonne National Laboratory. 
Revision: 0

Date: 10/31/97

Page B-68 of B-80

\section{Attachment B.1}

\section{RESRAD Inputs for the Dose Assessment}


B-1 Dose Conversion Factor for inhalation

$\mathrm{mrem} / \mathrm{pCi}$ DCF2

\section{RESRAD Default Values used for all isotopes listed in Table B5-2}

D-1 Dose Conversion Factor for Ingestion

mrem/pCi DCF3

Default Values Used, Listed in Table B5-4

D-34 Food Transfer Factors

dimensiontessRTF

Not Applicable to Area 6 Decon Pond Assessment

D-5 Bioaccumulation factors, fresh water

$\mathrm{L} / \mathrm{kg} \quad \mathrm{BIOFAC}$

Not Applicable to Area 6 Decon Pond Assessment

R011 Area of contaminated zone

$\mathrm{m}^{2}$

Area 6 DPF measures approximately $200^{\prime} \times 200^{\prime}$

Area $=200 \mathrm{ft} \times 200 \mathrm{ft} \times 0.0929 \mathrm{~m}^{2} / \mathrm{ft}^{2}$

Area $=\quad 3716 \mathrm{~m}^{2}$

RO11 Thickness of contaminated zone

m varies

\begin{tabular}{|llll|}
\hline zone 1 & $=0$ to $.5 \mathrm{ft}=$ & 0.1524 & $\mathrm{~m}$ \\
zone 2 & $=.5$ to $1 \mathrm{ft}=$ & 0.1524 & $\mathrm{~m}$ \\
zone 3 & $=1$ to $1.5 \mathrm{ft}=$ & 0.1524 & $\mathrm{~m}$ \\
zone 4 & $=1.5$ to $2 \mathrm{ft}=$ & 0.1524 & $\mathrm{~m}$ \\
zone 5 & $=2$ to $3 \mathrm{ft}=$ & 0.3048 & $\mathrm{~m}$ \\
zone 6 & $=3$ to $4 \mathrm{ft}=$ & 0.3048 & $\mathrm{~m}$ \\
zone 7 & $=4$ to $7 \mathrm{ft}=$ & 0.9144 & $\mathrm{~m}$ \\
\hline
\end{tabular}

RO11 Length parallel to aquifer flow

LCZPAQ

Maximizing the calculated possible length will maximize the calculated dose. The longest possible straight line is the line from corner to corner of the pond Length $=\mathrm{H}=$ square root of the sum of the square of the two sides

Length $=\quad 86.21046 \mathrm{~m}$ 


$\begin{array}{llcc}\text { Menu } & \text { Parameter } & \text { Units } & \text { Name } \\ \text { R011 } & \text { Basic Radiation Dose Limit } & \mathrm{mrem} / \mathrm{yr} & \text { BRDL }\end{array}$

Scenario 1 Radiological worker surveying and sampling sight

NV/YMP Senior Site Executives have established the annual NV/YMP facilities Administrative Control Level of $500 \mathrm{mrem} /$ year. The radiological worker in this assessment is assumed to be Rad Worker I or II qualified to perform their surveying and sampling duties. Their ALARA dose limit is then $500 \mathrm{mrem} / \mathrm{year}$. The value for $B R D L$ has no effect on the calculated doses.

\section{Basic Radiation Dose Limit for the radiological worker $=500$ mrem/year}

R011 Basic Radiation Dose Limit mrem/yr BRDL

Scenario 2: The industrial worker whose work location is on site

The industrial worker lives off the site, but the work location is at the Area 6 DPF. The BRDL for the industrial worker is based upon federal DOE Orders. The limit in DOE Order 5400.5 is $100 \mathrm{mrem} / \mathrm{yr}$ for the protection of the public from DOE activities.

Since an industrial worker could be on site as a member of the public, the $500 \mathrm{mrem} / \mathrm{yr}$ worker goal is not assumed. The limit chosen is $100 \mathrm{mrem} / \mathrm{yr}$.

Basic Radiation Dose Limit for the industrial worker $=100 \mathrm{mrem} / y e a r$

$\begin{array}{lll}\text { R011 Time since placement of material } & \text { years } & \text { T1 }\end{array}$

For the radiological worker scenario, the dose from residual radioactivity is assumed to start at time zero, the most conservative $\mathrm{T} 1$ value.

Scenario 1, radiological worker, the time since placement is 0 years.

The time when DOE institutional control is relinquished has not been established. It is assumed that it could occur subsequent to the 10-year period of active surveillance by radiological workers. This time period is much less than that assumed in other studies and is very conservative.

Scenario 2, the industrial worker the time is 10 years.

$\begin{array}{lll}\text { R011 Times for calculations } & \text { years } & \text { T2 }\end{array}$

Times assumed $=0,1,10,20,30,40,50,60,70,100,150,175,350,400,450,475,500$, $600,700,800,1000,1100,1200,1250,1300,1350,1400,1500,1600$, 1800 , and 2000 years 
Menu Parameter

R012 Initial principal radionuclides
Units Name

$\mathrm{pCi} / \mathrm{g} \quad \mathrm{S} 1$

The mean concentration for each radionuclide in each zone, based upon the data listed in the ITEMS data base, was used in the RESRAD calculations. In addition, DPF soil analytical data found in DOE/NV (1997) was used.

The $95 \%$ UCL was estimated by taking 1.96 sigma of the mean concentration for a soil analysis result and adding it to the mean concentration. The resultant concentration ( mean +1.96 sigma) was used as the input concentration to the RESRAD code. Sigma was assumed to be the square root of the mean. One exception was made. The plutonium-238 input is the mean concentration. The distribution of the data was so skewed, it is believed that the mean is a good representative value.

R012 Initial principal radionuclides

$\mathrm{pCi} / \mathrm{g} \quad \mathrm{S} 1$

\begin{tabular}{|c|c|c|c|c|c|c|c|}
\hline Isotope & zones 1 & 2 & 3 & 4 & 5 & 6 & 7 \\
\hline Co-60 & 61.13 & 34.0 & 0.30 & 0.30 & 0.41 & 4.58 & 0.34 \\
\hline Cs-137 & 28.29 & 26.7 & 0.00 & 0.00 & 0.00 & 2.27 & 0.00 \\
\hline Pu-238 & 0.47 & 0.39 & 0.11 & 0.18 & 0.19 & 0.08 & 0.08 \\
\hline Pu-239 & 4.45 & 4.57 & 0.08 & 0.08 & 0.08 & 0.08 & 0.08 \\
\hline Pu-240 & 4.45 & 4.57 & 0.08 & 0.08 & 0.08 & 0.08 & 0.08 \\
\hline Ra-226 & 0.00 & 5.86 & 6.00 & 4.81 & 1.50 & 0.00 & 0.00 \\
\hline Sr-90 & 9.64 & 4.82 & 0.51 & 1.61 & 0.07 & 0.00 & 0.00 \\
\hline Pb-210 & 0.00 & 0.00 & 2.49 & 1.29 & 0.00 & 0.00 & 0.00 \\
\hline $\mathrm{Pb}-212$ & 0.00 & 1.17 & 0.00 & 2.27 & 0.00 & 0.00 & 0.00 \\
\hline Am-241 & 4.79 & 3.79 & 0.85 & 0.85 & 0.85 & 0.85 & 0.85 \\
\hline Th-234 & 0.00 & 0.00 & 2.03 & 1.54 & 0.00 & 0.00 & 0.00 \\
\hline$A C-228$ & 0.00 & 1.08 & 1.40 & 0.00 & 0.00 & 0.00 & 0.00 \\
\hline
\end{tabular}

R012 Concentration in Groundwater $\quad$ pCi/L $\quad$ W1

Not Applicable to Area 6 Decon Pond Assessment

R013 Cover depth

m COVERO

No action scenario cover depth, zone $1=$ No action scenario cover depth, zone 2 = No action scenario cover depth, zone $3=$ No action scenario cover depth, zone $4=$ No action scenario cover depth, zone 5 = No action scenario cover depth, zone $6=$ No action scenario cover depth, zone $7=$
$0.1524 \mathrm{~m}$ $0.3048 \mathrm{~m}$ $0.4572 \mathrm{~m}$ $0.6096 \mathrm{~m}$ $0.9144 \mathrm{~m}$ $1.2192 \mathrm{~m}$ 
Units Name

\begin{tabular}{|lr}
\hline Engineered Cap Scenario $=2 \mathrm{ft}$ thick cap + 6" riprap , zone 1 $=$ & $0.762 \mathrm{~m}$ \\
Engineered Cap Scenario $=2 \mathrm{ft}$ thick cap + 6" riprap, zone 2 $=$ & $0.9144 \mathrm{~m}$ \\
Engineered Cap Scenario $=2 \mathrm{ft}$ thick cap + 6" riprap, zone $3=$ & $1.0668 \mathrm{~m}$ \\
Engineered Cap Scenario $=2 \mathrm{ft}$ thick cap + 6" riprap, zone 4 $=$ & $1.2192 \mathrm{~m}$ \\
Engineered Cap Scenario $=2 \mathrm{ft}$ thick cap + 6" riprap, zone $5=$ & $1.3716 \mathrm{~m}$ \\
Engineered Cap Scenario $=2 \mathrm{ft}$ thick cap + 6" riprap, zone 6 $=$ & $1.6764 \mathrm{~m}$ \\
Engineered Cap Scenario $=2 \mathrm{ft}$ thick cap + 6" riprap, zone 7 $=$ & $1.9812 \mathrm{~m}$
\end{tabular}

No action scenario: density is the default soll density =

Default factor of $1.00 \mathrm{E}-3 \mathrm{~m} / \mathrm{yr}$ was chosen

R013 Density of contaminated zone

$\mathrm{g} / \mathrm{cm}^{3}$

DENSCZ

Default factor of $1.5 \mathrm{~g} / \mathrm{cm}^{3}$ chosen

R013 Contaminated zone erosion rate $\mathrm{m} / \mathrm{yr} \quad$ VCZ

Adopted from DOE/NV (1997) and Yu et. al., (1993b)

$V C Z=R F \times t \times$ THICKO

$\begin{array}{lll}\mathrm{VCZ} & = & \text { Erosion rate of the contaminated zone } \\ \mathrm{RF} & = & \text { Resuspension factor (Shinn, 1986) }= \\ \mathrm{t} & = & \text { Number of seconds per year }= \\ \text { THICKO } & = & \text { Thickness of the contaminated zone varies }\end{array}$


Name

\begin{tabular}{|ccccc|}
\hline Zone \# & THICKO & t & RF & VCZ \\
\hline 1 & 0.1524 & $3.16 \mathrm{E}+7$ & $1.94 \mathrm{E}-11$ & $9.33 \mathrm{E}-5$ \\
2 & 0.1524 & $3.16 \mathrm{E}+7$ & $1.94 \mathrm{E}-11$ & $9.33 \mathrm{E}-5$ \\
3 & 0.1524 & $3.16 \mathrm{E}+7$ & $1.94 \mathrm{E}-11$ & $9.33 \mathrm{E}-5$ \\
4 & 0.1524 & $3.16 \mathrm{E}+7$ & $1.94 \mathrm{E}-11$ & $9.33 \mathrm{E}-5$ \\
5 & 0.3048 & $3.16 \mathrm{E}+7$ & $1.94 \mathrm{E}-11$ & $1.87 \mathrm{E}-4$ \\
6 & 0.3048 & $3.16 \mathrm{E}+7$ & $1.94 \mathrm{E}-11$ & $1.87 \mathrm{E}-4$ \\
7 & 0.9144 & $3.16 \mathrm{E}+7$ & $1.94 \mathrm{E}-11$ & $5.60 \mathrm{E}-4$ \\
\hline
\end{tabular}

R013 Contaminated zone total porosity

unitless TPCZ

Contaminated zone total porosity is from the

Resource Conservation and Recovery Act industrial Site Environmental Restoration Site Characterization Report Area 6 Decontamination Pond Facility (DOE/NV, 1997)

Contaminated zone total porosity $=\quad 0.4605$

R013 Contaminated zone effective porosity

unitiess

$\mathrm{EPCZ}$

Contaminated zone effective porosity is assumed to be equal to the total porosity $=0.4605$

$\begin{array}{llll}\mathrm{RO} 13 & \text { Contaminated zone hydraulic conductivity } & (\mathrm{m} / \mathrm{yr}) & \mathrm{HCCZ}\end{array}$

Contaminated zone total porosity is from the

Resource Consenvation and Recovery Act Industrial Site Environmental

Restoration Site Characterization Report Area 6 Decontamination Pond

Facility (DOE/NV, 1997). It states that measurements of hydraulic

conductivity from samples taken in the vicinity of the Area 6 DPF

showed $\mathrm{HCCZ}$ in the range of $2.49 \mathrm{E}-7$ to $5 \mathrm{E}-8 \mathrm{~cm} / \mathrm{s}$ or $>\quad 0.078578 \mathrm{~m} / \mathrm{yr}$

Contaminated zone hydraulic conductivity $=\quad 7.86 \mathrm{E}-2 \mathrm{~m} / \mathrm{yr}$

R013 Contaminated zone b parameter

unitless BCZ

From Yu et al., 1993b, Table 13-1, page 77, for sand

Contaminated zone b parameter $=\quad 4.05$

$\begin{array}{lr}\text { R013 Humidity in Air } & \left(\mathrm{g} / \mathrm{m}^{\star *} 3\right) \quad \text { HUMID }\end{array}$

RESRAD default value of $8 \mathrm{~g} / \mathrm{m}^{3}$ was assumed 
Menu Parameter Units Name

R013 Evapotranspiration coefficient unitless EVAPTR

Calculated using the equation 12.1 on page 70 of Yu et al., 1993b

$\mathrm{Ce}=\mathrm{ETr} /((1-\mathrm{Cr}) \mathrm{Pr}+\mathrm{IRr})$ where

$\mathrm{Ce}=$ Evapotranspiration coefficient

$E T r=$ evapotranspiration rate, Figure 12-1(Yu et al., 1993b) $=$

$\mathrm{Cr}=$ runoff coefficient, Table 10-1, pg 66 (Yu et al., 1993b) =

0.2

$\mathrm{Pr}=$ precipitation $(\mathrm{DOE} / \mathrm{NV}, 1996 \mathrm{a})=$

$0.15 \mathrm{~m} / \mathrm{yr}$

$\mathrm{IRr}=$ irrigation rate assuming a $70 \%$ irrigation efficiency =

$\mathrm{IRr}=(1.2-0.15) / 0.7=$

1.2 = water required per year to raise garden or farm $(\mathrm{m} / \mathrm{yr})$

$0.15=$ average precipitation at lower elevations at NTS

0.7 = irrigation efficiency, mid-range, pg 68 (Yu et al., 1993b)

$\mathrm{Ce} \quad 0.69$

R013 Precipitation Rate

$\mathrm{m} / \mathrm{yr} \quad$ PRECIP

Precipitation from DOE/NV (1996a)

\begin{tabular}{|lll}
\hline Precipitation $=$ & $15 \mathrm{~cm} / \mathrm{yr}=$ & $0.15 \mathrm{~m} / \mathrm{yr}$ \\
\hline
\end{tabular}

R013 Runoff coefficient

unitless RUNOFF

$C r=$ runoff coefficient, Table 10-1, pg 66 (Yu et al., 1993b) $=$

R013 Watershed area for nearby streams or pond

$m^{2}$

WAREA

Minimizing the area will maximize the calculated dose therefore; the area of the Area 6 DPF will be used as the value for WAREA. This is also the minimum value acceptable to RESRAD.

WAREA $=\quad 3716 \mathrm{~m}^{2}$

R013 Accuracy for water/soil computation

unitless

Default value of 1.00E-3 is assumed for accuracy for waterisoil computation

R014 Density of the saturated zone

$\mathrm{g} / \mathrm{cm}^{3} \quad$ DENSAQ

Density of the saturated zone is assumed to equal default value = 
Saturated zone total porosity is the same as TPCZ and is from the Resource Conservation and Recovery Act Industrial Site Environmental Restoration Site Characterization Report Area 6 Decontamination Pond Facility (DOE/NV, 1997)

Saturated zone total porosity $=\quad 0.4605$

R014 Saturated zone effective porosity

unitiess

EPSZ

Saturated zone effective porosity is assumed to be equal to the total porosity $=\quad 0.4605$

$\begin{array}{llll}\text { RO14 Saturated zone hydraulic conductivity } & (\mathrm{m} / \mathrm{yr}) \quad \mathrm{HCCZ}\end{array}$

Saturated zone total porosity is from the

Resource Conservation and Recovery Act Industrial Site Environmental Restoration Site Characterization Report Area 6 Decontamination Pond Facility (DOE/NV, 1997). It states that measurements of hydraulic conductivity from samples taken in the vicinity of the Area 6 DPF showed $\mathrm{HCCZ}$ to be in the range of $2.49 \mathrm{E}-7$ to $5 \mathrm{E}-8 \mathrm{~cm} / \mathrm{s}$ or $>0.078578 \mathrm{~m} / \mathrm{yr}$

Saturated zone hydraulic conductivity $=\quad 7.86 \mathrm{E}-2 \mathrm{~m} / \mathrm{yr}$

RO14 Saturated zone hydraulic gradient unitless HGWT

The change in the hydraulic head at Yucca Lake is considered insignificant Therefore, based upon personal communications with Ed Thomas of IT Corporation in March 1997, the saturated zone hydraulic gradient is expected to be near zero. Ed Thomas approved a value of $1.0 \mathrm{E}-4$ as a fair approximation.

Saturated zone hydraulic gradient $=\quad$ 1.00E-04

RO14

Saturated zone b parameter unitless

BSZ

From Yu et al., 1993b, Table 13-1, p 77, for sand

Saturated zone $\mathrm{b}$ parameter $=$ 4.05

R014 Water table drop rate

m/yr WWT

Water table drop rate is conservatively assumed to $=$ 1.00E-04 
Menu Parameter Units Name

$\begin{array}{llll}\text { R014 Well pump intake depth below the water table } & \text { DWBWT }\end{array}$ Default value of $10 \mathrm{~m}$ is chosen for DWIBWT

RO14 Model: Nondispersion (ND) or Mass-Balance (MB)

MODEL

Nondispersion model chosen for RESRAD (ND)

RO14 Well pumping rate $\quad \mathrm{m}^{3} / \mathrm{yr}$
No on site well is assumed for rad worker or industrial worker scenario

R015 Number of unsaturated zone strata NS

Number of unsaturated zone strata $=\quad 1$

RO16 Distribution coefficients

$\mathrm{cm}^{3} / \mathrm{g} \quad$ DCNUCC

Default coefficients for all zones

\begin{tabular}{|lcl|}
\hline Element & DCNUCC & Source \\
\hline $\mathrm{U}$ & 35 & Table 32.1, sand, pg 105 Yu et. al., 1993b, \\
$\mathrm{Pu}$ & 550 & Table 32.1, sand, pg 105 Yu et. al., 1993b, \\
$\mathrm{Am}$ & 35 & Technical advice, W. Hansen LANL \\
$\mathrm{Ac}$ & 450 & Table 32.1, sand, pg 105 Yu et. al., 1993b, \\
$\mathrm{Np}$ & 5 & Table 32.1, sand, pg 105 Yu et. al., 1993b, \\
$\mathrm{Pa}$ & 550 & Table 32.1, sand, pg 105 Yu et. al., 1993b, \\
$\mathrm{Pb}$ & 270 & Table 32.1, sand, pg 105 Yu et. al., 1993b, \\
$\mathrm{Ra}$ & 500 & Table 32.1, sand, pg 105 Yu et. al., 1993b, \\
$\mathrm{Th}$ & 3200 & Table 32.1, sand, pg 105 Yu et. al., 1993b, \\
$\mathrm{Sr}$ & 15 & Table 32.1, sand, pg 105 Yu et. al., 1993b, \\
$\mathrm{Cs}$ & 280 & Table 32.1, sand, pg 105 Yu et. al., 1993b, \\
$\mathrm{Co}$ & 60 & Table 32.1, sand, pg 105 Yu et. al., 1993b, \\
\hline
\end{tabular}

R015 Unsaturated zone thickness

m $\quad H(1)$

Based upon information in DOE/NV (1997), the unsaturated zone thickness is assumed to $=500 \mathrm{~m}$.

RO16 Leach rate

$y r^{-1}$

ALEACH

RESRAD calculates ALEACH from DCNUCC

RO16 Solubility constant

unitless SOLUBK

RESRAD calculates SOLUBK from ALEACH 


$\begin{array}{llcc}\text { Menu Parameter } & \text { Units } & \text { Name } \\ \text { R017 Inhalation rate } & \mathrm{m}^{3} / \mathrm{yr} & \text { INHALR }\end{array}$

\section{Radiological Worker Exposure Scenario}

The radiological worker is assumed to walk the site, gather filters from monitors, and perhaps monitor the site with portable survey instruments. This is not strenuous work, so an inhalation rate for moderate work from Layton (1993) was adopted. It was assumed that the radiological worker is in the age group of 20 to 49 , and the age and sex specific data found in Table 7 of Layton (1993) were averaged.

\begin{tabular}{|llccc|}
\hline Age & Sex & $\begin{array}{c}\text { Duration } \\
\text { h/d }\end{array}$ & $\begin{array}{c}\text { Inhalation } \\
\mathrm{m}^{3} / \mathrm{d}\end{array}$ & $\begin{array}{c}\text { Rate } \\
\mathrm{m}^{3} / \mathrm{h}\end{array}$ \\
\hline $20-34$ & $\mathrm{M}$ & 1.2 & 2.1 & 1.75 \\
$20-34$ & $\mathrm{~F}$ & 1.2 & 1.8 & 1.50 \\
$35-49$ & $\mathrm{M}$ & 1.4 & 2.4 & 1.71 \\
$35-49$ & $\mathrm{~F}$ & 1.4 & 1.8 & 1.29 \\
Mean $\mathbf{m}^{\star \star 3 / h}$ & & & $\mathbf{1 . 5 6}$ \\
\hline
\end{tabular}

RESRAD requires that the inhalation be input as an annual rate. The radiological worker is assumed to be on site $1.03 \mathrm{~h} / \mathrm{yr} \times 1.56 \mathrm{~m}^{3} / \mathrm{h}=1.61 \mathrm{~m}^{3} / \mathrm{yr}$. However, RESRAD also multiplies the annual inhalation rate by the fraction of time the worker is on site. Therefore the inhalation rate, $1.56 \mathrm{~m}^{3} / \mathrm{h}$ has to be multiplied by the hours in a year for RESRAD input. Multiplying the hourly inhalation rate by $h / y r$ will result in RESRAD using $1.56 \mathrm{~m}^{3} / \mathrm{h}$.

Inhalation $=1.56 \mathrm{~m}^{3} / \mathrm{h} \times 24 \mathrm{~h} / \mathrm{d} \times 365 \mathrm{~d} / \mathrm{yr}=$ $13666 \mathrm{~m}^{3} / \mathrm{yr}$

\section{Industrial Worker Exposure Scenario}

Yu et. al., recommends the following worst-case activity levels for an individual performing indoor work (1993b, pg 124). Using the data from Table 7 of Layton, the mean inhalation rate $\left(\mathrm{m}^{3} / \mathrm{h}\right)$ is calculated as shown below.

\begin{tabular}{|lccc|}
\hline Activity & $\begin{array}{c}\text { Fraction } \\
\text { of time }\end{array}$ & $\begin{array}{c}\mathbf{~ m}^{3} / \mathbf{h} \\
\text { for activity }\end{array}$ & $\begin{array}{c}\mathbf{~ m}^{\mathbf{3}} \mathbf{~} \\
\text { per activity }\end{array}$ \\
\hline Resting & 0.25 & 0.59 & 0.15 \\
Light activity & 0.60 & 0.59 & 0.35 \\
Moderate & 0.10 & 1.56 & 0.16 \\
Heavy & 0.05 & 3.90 & 0.19 \\
Mean $\mathrm{m}^{3} / \mathrm{h}$ & & & 0.85 \\
\hline
\end{tabular}


The annual inhalation rate required for RESRAD is $0.85 \times 2,000 \mathrm{~h} / \mathrm{yr}=1700 \mathrm{~m}^{3} / \mathrm{yr}$. RESRAD adjusts the INHALR input by multiplying it by the fraction of time the dose receptor is on site. Therefore the inhalation rate must be adjusted upward by assuming the dose receptor is on site 24 hours/day for 365 days/year. Multiplying the $0.85 \mathrm{~m}^{3} / \mathrm{h}$ by hours $/ \mathrm{yr}=7452 \mathrm{~m}^{3} / \mathrm{yr}$. When RESRAD multiplies 7452 by the fraction of time the industrial worker is on site 0.2282 , the result inhalation rate is $1700 \mathrm{~m}^{3} / \mathrm{yr}$.

Inhalation $=0.85 \mathrm{~m}^{3} / \mathrm{h} \times 24 \mathrm{~h} / \mathrm{d} \times 365 \mathrm{~d} / \mathrm{yr}=$

Mass Loading for Inhalation

\section{$7452 \mathrm{~m}^{3} / \mathrm{yr}$}

$$
\mathrm{g} / \mathrm{m}^{3} \quad \text { MLINH }
$$

Mass loading of respirable particles in air in Area 6 has not been published. A great deal of mass loading data has been taken at TTR and Nellis, but those data are not applicable to Area 6 DPF because the soil surface at TTR is characterized by a cobblestone desert pavement while the Decon Pond is in a playa where the surface of the soil is more bare to the wind for resuspension. The high end of the range recommended in Yu et al., pg 110 for nonurban areas is is used for RESRAD input (Yu et. al., 1993b)

\begin{tabular}{|lll}
\hline Mass loading for inhalation $=$ & $7.90 \mathrm{E}-05 \mathrm{~g} / \mathrm{m}^{3}$ \\
\hline
\end{tabular}

$$
\text { Default value for dilution length is adopted }=\mathbf{3} \mathbf{~ m}
$$

\section{RO17}

$$
\text { Exposure Duration }
$$

yr

ED

\section{Default value for exposure duration is assume $=30$ yrs}

All shielding factors are multiplicative adjustors to the calculated inhalation rate. If the shielding factor for any parameter is 1 , then there is no reduction. If the shielding factor was 0.5 , the parameter would be reduced to $50 \%$ of the unadjusted value. This is true for all shielding factors. 
Units Name

R017 Shielding factor for external gamma

unitless SHF1

Radiological worker shielding factor for external gamma $=$

Industrial worker shielding factor for external gamma assumes default $=$

R017 Fraction of time spent indoors on the site

unitless

FIND

Radiological worker is assumed to spend no time indoors on site

Fraction of time spent in doors on site by the radiological worker $=$

R017 Fraction of time spent indoors on the site (continued)

Industrial worker is assumed to be indoors on site $100 \%$ of time.

Fraction of time $=(8 \mathrm{~h} / \mathrm{d} \times 5 \mathrm{~d} / \mathrm{w} \times 50 \mathrm{w} / \mathrm{yr}) \pi(365 \mathrm{~d} / \mathrm{yr}) \times(24 \mathrm{~h} / \mathrm{d})]=$

Fraction of time spent indoors on the site by industrial worker $=$

R017 Fraction of time spent outdoors on site

unitless FOTD

Radiological worker is assumed to check the site four times per year If the radiological worker walks the entire site at a rate of $1 \mathrm{~m} / \mathrm{s}$ and covers an area of $1 \mathrm{~m}^{2}$ while walking, then the time it takes to survey the site:

Time $=(3716$ seconds/check $\times 4$ checks $/ y r) /(3600 \mathrm{~s} / \mathrm{h})=4.128889 \mathrm{~h} / \mathrm{yr}$

Assume a safety factor of 2, resulting in twice the calculated time spent outdoors on site.

Fraction of time spent outdoors on site by rad worker $=\quad \mathbf{0 . 0 0 0 9 4 3}$

Fraction of time spent outdoors on site by industrial worker $=0.0$

R017 Shape factor flag, external gamma unitless FS

Shape factor flag is set to the default value $=\mathbf{1 . 0 0}$

RO17 Radii of shape factor array m RAD_SHAPE

Radii of shape factor array is not used in this analysis 
RO18 Ingestion Pathways

The only ingestion pathway assumed for the rad worker and the industrial worker is soil ingestion. No resident is assumed to live on the Area 6 DPF and no food is grown or raised on site by either the radiological worker or the industrial worker.

R018 Soil Ingestion

$g / y r \quad$ SOIL

The radiological worker is assumed to ingest $0.05 \mathrm{~g} / \mathrm{d}$ based upon the recommendations of Yu et al., pg115 (1993b). RESRAD adjust the soil ingestion rate by multiplying it times the fraction of time the dose receptor is on site. The same soil ingestion rate is assumed for the industrial worker.

Radiologcial worker soil ingestion rate $=0.05 \times 365 \mathrm{~d} / \mathrm{yr}=$ $18.25 \mathrm{~g} / \mathrm{yr}$

Industrial worker soil ingestion rate $=0.05 \times 365 \mathrm{~d} / \mathrm{yr}=$ $18.25 \mathrm{~g} / \mathrm{yr}$

RO19 This section is concerned with the food ingestion pathways.

This pathway is irrelevant to the radiological worker and industrial worker scenarios

C-14 This section is concerned with C-14 pathway; $\mathrm{C}-14$ is not a source term in this analysis.

STOR This section is concerned with food storage times and is not pertinent to the radiological worker or industrial worker scenario

RO21 This section is concerned with radon dose pathway. The default values for all parameters are chosen except for the following.

Total porosity of the cover material $=\quad 0.4605 \mathrm{TPCV}$

Building depth below ground surface $=\quad 0 \mathrm{~m} \quad$ DMFL

$\begin{array}{llll}\text { RO21 Annual average wind speed } & \mathrm{m} / \mathrm{s} & \text { WIND }\end{array}$

The annual average wind speed is from the NTS Annual Site Environmental Report (DOE/NV, 1996a).

Annual average wind speed $=11 \mathrm{~km} / \mathrm{h}=3.1 \mathrm{~m} / \mathrm{s}$ 
Revision: 0

Date: $10 / 31 / 97$

Page C-1 of C-11

\section{Appendix C}

\section{Cost Estimates \\ Area 6 Decontamination Pond Facility}

(Included as submitted by Bechtel Nevada) 
TO: ALLISON URBON - Remediation Project Task Manager

FROM: BRUCE WILCOX - RP Project Controls

SUBJECT: NO ACTION - DECON POND REMEDIATION

TEC:

$\$ 153,539$

WORK PACKAGE: CAU 92: AREA 6 DECON POND / NTS

LOCATION: NTS - AREA 6

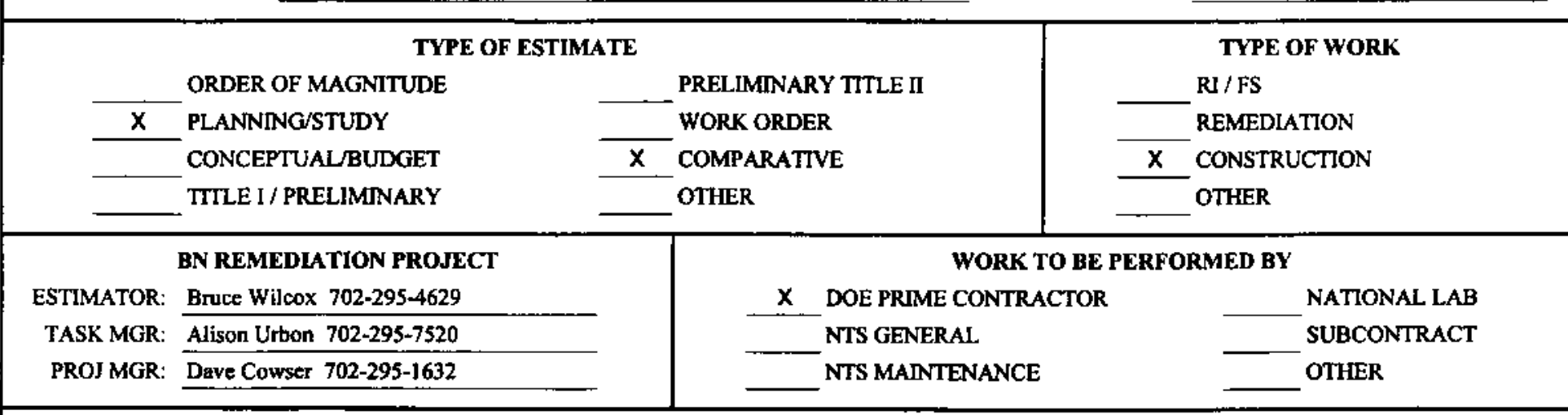

STATEMENT OF WORX:

This estimate has been prepared at the request of DOENV for closure of Corrective Action Unit (CAU) 92, an environmental restoration site listed in the Federal Facilities and Consent Order (FFACO). This and three other closure options estimates will be used to identify the closure option that will be the ieast costly while being protective of buman health and the environment and meeting regulatory closure requirements. These estimates will be incorporated into the overall evaluation of options presented within a Corrective Measures Study being compiled by another contractor.

\section{SCOPE:}

Re-apply soil cement to interior of bern and pond bottom to eliminate dust with radionuclides from blowing from the pond during high winds. Conduct site inspection during/after each rain event (assume 4 per year). Maintain surveillance data file and inform DOE with yearly lettet/report. Provide post closure surveillance for 10 years.

\section{BASIS OF ESTIMATE:}

- Contingency costs are not included in this estimate. All costs are in FY98 dollars.

- The cost of preparing the Closure PJan and related documents is not included because it will be approximately the same cost for ail options and will not affect the overall difference in costs between closure options.

- A sump, tocated outside the pond and within the Area 6 Decon Facility, and piping leading from the sump to the pond are also a part of this corrective action. Under this option, nothing will be done with the sump and piping (6-inch inside diameter clay pipe, approximately 550-feet long).

- The pond (measuring approx. $200^{\prime} \times 200^{\prime}$ ) is located on the south end of Yucca Lake playa which NDEP considers to be "waters of the State of Nevada". Clostre must be protective of surface water as well as ground water.

See following page/s for continuation and cost summary

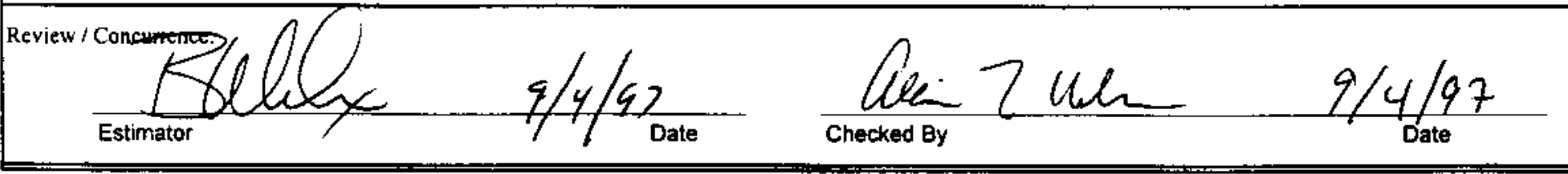




\section{BASIS OF ESTIMATE cont :}

- The pond is bermed on all four sides with berms that are approximately 4 feet above surrounding playa surface with variable widths of 30-55 feet at the base of the berm and approximately 15 feet wide at the top based on surveyor maps.

- The bottom of the pond is approximately 4 feet lower in elevation than surrounding land surface based on surveyor maps and visual observation. A chain link fence currently surrounds pond berms.

- The top foot of material within the pond and the inside walls of the berms contains the majority of contamination.

- Closure of this site must be done in accordance with RCRA (hazardous waste) closure, which requires either clean closure or closure in place as a landfill; therefore, THE "NO ACTION" ALTERNATIVE WILL NOT MEET REGULATORY REQUIREMENTS FOR CLOSURE OF THIS SITE.

\section{ASSUMPTIONS:}

- Assumes that the site will be checked during/after each rain event, results will be documented and filed. One event per year will require follow-up documentation in a letter to DOE. Assumes 4 rain events each year. Surveillance will continue for 10 years post closure.

- Soil cement was applied to pond bottom and berm sides in 1996. Assumes soil cement will need to be re-applied to the entire interior of the pond (including inside berms) to control dust with radionuclides from blowing from the pond during high winds. Recent characterization sampling activities have disturted the previous application.

- Interior surface of berm and pond bottom will be disked using grader with disk attachment to loosen existing soil cement. Soil cement will be mixed in water truck and apply to berm and pond surfaces. The mixture will be compacted with a vibrating roller. Assume workers in the pond witl be required to wear PPE and respirators during construction. Assume all equipment in pond will require decon.

- Assume no maintenance or remedial action will be possible in the event of a 25-year, 24-hour or 100-year flood. This assumption is based on conservative estimates that indicate water leveis may exceed the height of the berms by up to 2 and 7 feet, respectively, for each event.

- Assume soil cement coating will protect pond bottom and bern sides for 10 years before reapplication is required.

\section{CONTINGENCY:}

Contingency costs are not inciuded in this estimate. All costs are in FY98 dollars.

$$
\text { COST SUMMARY - TOTAL ESTIMATED COST: }
$$

REMEDIATION PROJECT - SURVEILLANCE \& REPORTING 
SURECT: CIP ENG CAP - DECON POND REMEDIATION

TEC:

$\$ 996,873$

WORK PACKAGE: CAU 92: AREA 6 DECON POND / NTS

LOCATION: NTS - AREA 6

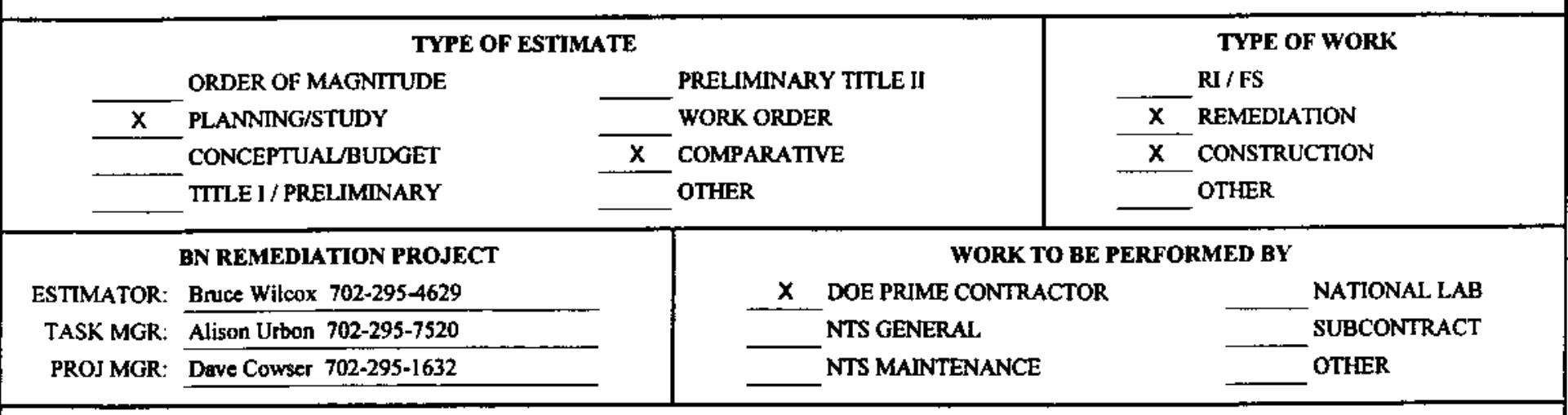

STATEMENT OF WORR:

This estimate has been prepared at the request of DOE/NV for closure of Corrective Action Unit (CAU) 92, an environmental restoration site listed in the Federal Facilities and Consent Order (FFACO). This and three other closure options estimates will be used to identify the closure option that will be the least costly while being protective of human health and the environment and meeting regulatory closure requirements. These estimates will be incorporated into the overall evaluation of options presented within a Corrective Measures Study being compiled by another contractor.

\section{SCOPE:}

Excavate and dispose sump and 550 if $6^{n}$ concrete pipe at NTS Area 5 pit 3 . Push bermed soil into decon pond and construct engineered cap̣. Re-install existing fence on completion. Provide post closure monitoring for 10 years.

\section{BASIS OF ESTIMATE:}

- Contingency costs are not included in this estimate. All costs are in FY98 dollars.

- The cost of preparing the Closure Plan and related documents is not included because it will be approximately the same cost for all options and will not affect the overali difference in costs between closure options.

- A sump, located outside the pond and within the Area 6 Decon Facility, and piping leading from the sump to the pond are also a part of this corrective action. The sump and piping (6-inch inside diameter clay pipe, approximately 550-feet long) will be excavated and disposed as mixed waste below Land Disposal Restriction (LDR) levels.

- The pond (measuring approx. 200' x 200') is located on the south end of Yucca Lake playa which NDEP considers to be "waters of the State of Nevada". Closure must be protective of surface water as well as ground water.

- The pond is bermed on all four sides with berms that are approximately 4 feet above surrounding playa surface with variable widths of $30-55$ feet at the base of the berm and approximately 15 feet wide at the top based on surveyor maps.

See following page/s for contimuation and cost summary

Review / Concurrence:

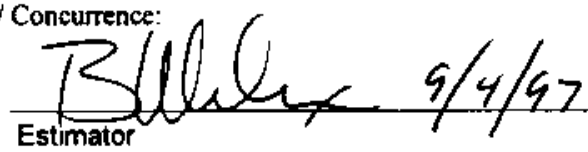




\section{BASIS OF ESTIMATE cont:}

- The bottom of the pond is approximately 4 feet lower in elevation than surrounding land surface based on surveyor maps and visual observation. A chain link fence currently surrounds pond berms.

- The top foot of material within the pond and the inside walts of the berms contains the majority of contamination.

- Closure of this site must be done in accordance with RCRA (hazardous waste) closure, which requires either clean closure or closure in place as a iandfill.

\section{ASSUMPTIONS:}

- Assume all waste will be mixed (i.e., low-level radioactive waste and hazardous waste). Approx. 1,000 cf of waste (pipe, concrete debris from sump, limited amount of trench soil, \& PPE) will be placed in B-25 boxes and transported to NTS Area 5 for disposal.

- Proposed FY98 unit cost for mixed waste disposal at the NTS includes NTS Low Level Rad Waste fee (\$16/cf), State fee (\$26/ton), and

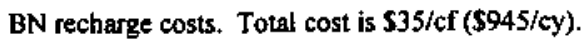

- Assume workers will require full PPE and respirators for removai of pipe and sump debris. Continuous RCT support will be required during removal activities.

- Assume confirmation sampling and analysis of waste will be required for disposal. Assume confirmation sampling of soils surrounding sump and pipe will be required prior to backfill/closure.

- Assume berms were formed with material excavated from pond.

- Assume BN will provide all engineering, labor, and equipment support for construction of the engineered cap. All labor costs are based on $10 \mathrm{hrs} /$ day, 4 days/week.

- Assume a cap model will be designed, constructed adjacent to the pond, and tested to insure that the cap will meet regulatory and design requirements. The final engineered cap will be based on the model design following testing and evaluation.

- Assume berms will be pushed into the pond and will fill approximately $60 \%$ of the pond, including compaction. Approx, 5,900 cy of native, low-permeability cap materials will be imported from the lake bed $1 / 2$ mile from the pond to complete the fill and construct the engineered cap.

- Assume native material available from Yucca playa will meet the requirements for a RCRA cap. (RCRA closure in place requires an engineered cap to be less permeable than the bottom of the unit.)

- Assume a low-permeability $2 \mathrm{ft}$ thick cap (measuring approx $300^{\prime} \times 300^{\prime}$ ) will be constructed above the backfilled pond. The cap will be approx. $2 \mathrm{ft}$ higher than the existing playa at the center. BN will provide survey support to insure design specifications for engineered cap are met and to provide specifications for as-built drawings.

- Assumes piaya material will be excavated and transported using earth moving scrapers. 6 inches of Type II material (approx $1,800 \mathrm{cy}$ ) will be imported from the NTS Cement Plant and placed on top of low-permeability layer to protect cap from errosion.

- Water will be applied to the imported material for dust control and compaction. Assume water trucks and heavy equipment will compact playa and Type II materials to $90 \%$.

- Assume 4 dump trucks with 18 cubic yard capacity will be used to import Type II from the NTS Cement Plant. Cycle time for each truck is 8 10 loads per day.

- Assume existing chain-link fence will be removed for construction activities and re-installed at the same location on completion.

- Assume field work will be complete in 6 weeks.

- Assumes no monitoring weils are required

- Assumes post-closure monitoring will consist of visual inspection and maintenance of the engineered cap.

- Assumes post-closure monitoring to be monthly for the first year and quarterly thereafter for at least nine more years (total ten years). 


\section{EST: $\quad$ CIP_CAP.98}

\section{CONTINGENCY:}

Contingency costs are not included in this estimate. All costs are in FY98 dollars.

$$
\text { COST SUMMARY - TOTAL ESTMMATED COST: }
$$

TEC - ENGINEERED CAP / TEST MODEL DESIGN

TEC - CLOSURE REPORT FIELD WORK

463,150

TEC - WASTE MANAGEMENT AND DISPOSAL - SUMP AND PIPE ONLY

TEC - POST CLOSURE MONITORING - FY99 - FYOS (10 years post closure includes escalation) 
FROM: BRUCE WILCOX - RP Project Controls

SUBJECT: CLEAN CLOSURE - DECON POND REMEDIATION

WORK PACKAGE: CAU 92: AREA 6 DECON POND / NTS
TEC: $\$ 16,655,975$

\section{TYPE OF ESTIMATE}

ORDER OF MAGNITUDE

X PLANNING/STUDY CONCEPTUAL/BUDGET TITLE I / PRELIMINARY

\section{BN REMEDIATION PROJECT}

ESTIMATOR: Bruce Wilcox 702-295-4629

TASK MGR: Alison Urbon 702-295-7520

PROJ MGR:

Dave Cowser 702-295-1632

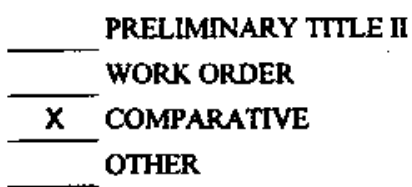

LOCATION: NTS - AREA 6

\begin{tabular}{l} 
WORK TO BE P \\
$X \quad$ DOE PRIME CONTRACTOR \\
NTS GENERAL \\
\hline$\ldots$ NTS MAINTENANCE
\end{tabular}

TYPE OF WORK

RI / FS

$\begin{array}{ll}x & \text { REMEDIATION } \\ x & \text { CONSTRUCTION } \\ & \text { OTHER }\end{array}$

\section{STATEMENT OF WORK:}

This estimate has been prepared at the request of DOE/NV for closure of Corrective Action Unit (CAU) 92, an environmental restoration site listed in the Federal Facilities and Consent Order (FFACO). This and three other closure options estimates will be used to identify the closure option that will be the least costly while being protective of human health and the environment and meeting regulatory closure requirements. These estimates will be incorporated into the overall evaluation of options presented within a Corrective Measures Study being compiled by another contractor.

\section{SCOPE:}

Excavate and dispose sump, 550 lf $6^{\prime \prime}$ concrete pipe, all berm soils, and pond soils to a depth of $7 \mathrm{ft}$. deep at NTS Area 5 pit 3 . Backfill excavated pond up to existing playa elevation with native playa soils. Engineered cap will not be required. Post closure monitoring will not be required.

\section{BASIS OF ESTIMATE :}

- The cost of preparing the Closure Ptan and related documents is not included because it will be approximately the same cost for all options and will not affect the overall difference in costs between closure options.

- A sump, located outside the pond and within the Area 6 Decon Facility, and piping leading from the sump to the pond are also a part of this corrective action. The sump and piping (6-inch inside diameter clay pipe, approximately 550 -feet long) will be excavated and disposed as mixed waste below Land Disposal Restriction (LDR) levels.

- The pond (measuring approx. $200^{\prime} \times 200^{\circ}$ ) is located on the south end of Yucca Lake playa which NDEP considers to be "waters of the State of Nevada". Closure must be protective of surface water as well as ground water.

See following page/s for continuation and cost summary

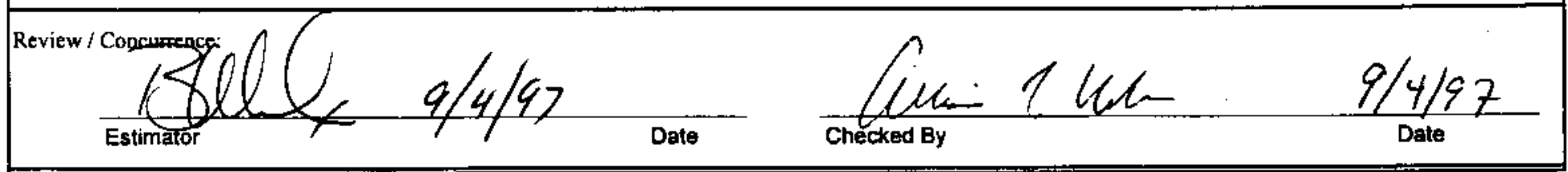




\section{BASIS OF ESTIMATE cont:}

- The pond is bermed on all four sides with berms that are approximately 4 feet above surrounding playa surface with variable widths of 30-55 feet at the base of the berm and approximately 15 feet wide at the top based on surveyor maps.

- The bottom of the pond is approximately 4 feet lower in elevation than surrounding land surface based on surveyor maps and visual observation. A chain link fence currently surrounds pond berms.

- The top foot of material within the pond and the inside walls of the berms contains the majority of contamination.

- Closure of this site must be done in accordance with RCRA (hazardous waste) closure, which requires either clean closure or closure in place as a landfill.

\section{ASSUMPTIONS:}

NOTE: The following estimate aseumes mixed waste soil will be accepted for dispossi at pit 3 in Ares 6 in burrito wrapped contniners.

- Assumes all contamination is mixed waste below LDR levels (i.e., low-level radioactive waste and hazardous waste). Approx. 1,000 cf of waste (pipe, concrete debris from sump, and PPE) will be placed in B-25 boxes for on-site disposal. Pond soils to $7 \mathrm{ft}$. deep, all berm soils, and minimal trench soils (approx. 15,000 cy total) will be excavated and place in burrito lined end dump trucks for on-site disposal.

- Proposed FY98 unit cost for mixed waste disposal at the NTS includes NTS Low Level Rad Waste fee (\$16/cf), State fee (\$26/ton), and BN recharge costs. Total cost is $\$ 35 / \mathrm{cf}(\$ 945 / \mathrm{cy})$.

- Assume workers will require full PPE and respirators for removal of pipe and sump debris. Equipment operators and other personnel required to work in the pond during excavation will also be required full protection. Continuous RCT support will be required during removal and excavation activities.

- Assume confirmation sampling and analysis of waste will be required for disposal. Assume post construction confirmation sampling of soils under pond and berms will be required for clean close.

- Assume BN will provide all engineering, craft labor, and equipment support for excavation and backfill operations. All on-site labor costs are based on $10 \mathrm{hrs} /$ day, 4 days/week.

- Assume transportation to Area 5 will be provide by NTS construction. Assume 6 trucks with minimal 16 cy capacity (approx. 950 loads) will be required. Truck cycle time is $1.5-2$ hrs including RCT check, burrito liner placement and finish, and truck weighing. Average truck speed of $35 \mathrm{MPH}$, distance is 10 miles one way. Each load will be weighed, certified, and documented.

- Approx, 10,400 cy of native soil will be imported from the lake bed $1 / 2$ mile from the site to fill the excavated pond. Assumes playa material will be excavated and transported using earth moving scrapers. Water will be applied to the inported material for dust control and compaction. Assume water trucks and heavy equipment will compact płaya materiais to approx. $90 \%$ during backfill activities to prevent subsidence. Assume playa will self level to it's natural elevation with the first few rain events following completion of construction.

- Assume engineered cap will not be required.

- Assume existing fence will not be re-installed.

- Assume post-closure surveillance will not be required.

\section{CONTINGENCY:}

Contingency costs are not included in this estimate. Al] costs are in FY98 dollars.

$$
\text { COST SUMMARY - TOTAL ESTHMATED COST: }
$$


SUBJECT: CIP PARTIAL EXCAVATION - DECON POND REMEDIATION

TEC:

$\$ 2,930,477$

WORK PACKAGE: CAU 92: AREA 6 DECON POND / NTS

LOCATION: NTS - AREA 6

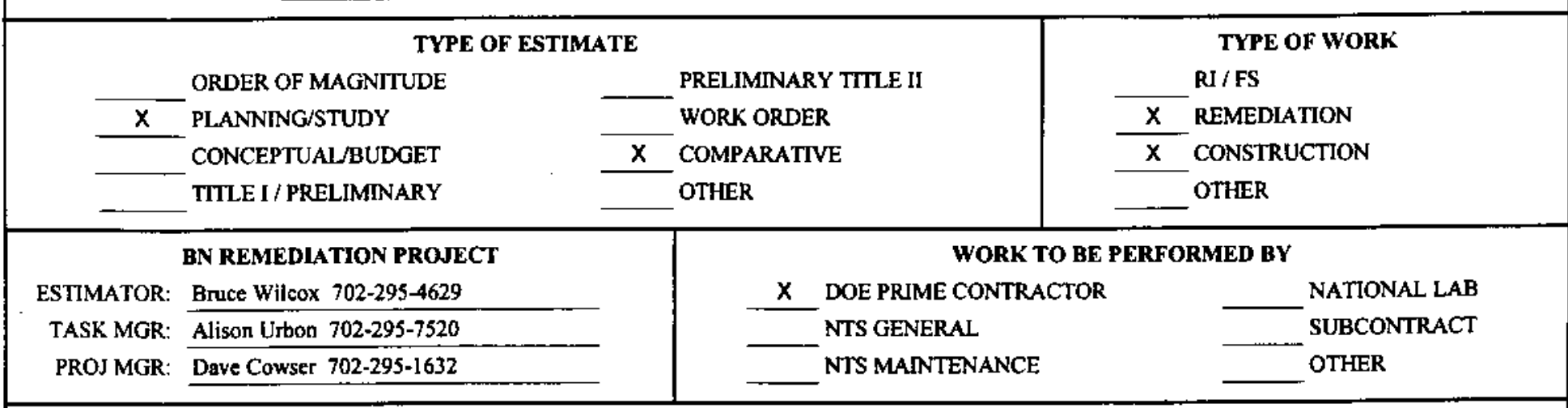

\section{STATEMENT OF WORK:}

This estimate has been prepared at the request of DOENV for closure of Corrective Action Unit (CAU) 92, an environmental restoration site listed in the Federal Facilities and Consent Order (FFACO). This and three other closure options estimates will be used to identify the closure option that will be the least costly while being protective of human health and the environment and meeting regulatory closure requirements. These estimates will be incorporated into the overall evaluation of options presented within a Corrective Measures Study being compiled by another contractor.

\section{$\underline{S C O P E}$ :}

Excavate and dispose concrete sump, 550 If 6" concrete pipe, $1 \mathrm{ft}$. of soil from pond bottom and berm sides at NTS Area 5 pit 3 . Push remaining bermed soil into decon pond \& construct engineered cap. Reinstall fence and install signage. Provide post closure monitoring for 10 years.

\section{BASIS OFESTIMATE:}

- Contingency costs are not included in this estimate. All costs are in FY98 dollars.

- The cost of preparing the Closure Plan and related documents is not included because it will be approximately the same cost for all options and will not affect the overall difference in costs between closure options.

- A sump, located outside the pond and within the Area 6 Decon Facility, and piping leading from the sump to the pond are also a part of this corrective action. The sump and piping (6-inch inside diameter clay pipe, approximateiy 550-feet long) will be excavated and disposed as mixed waste below Land Disposal Restriction (LDR) levels.

- The pond (measuring approx. $200^{+} \times 200^{\prime}$ ) is located on the south end of Yucca Lake playa which NDEP considers to be "waters of the State of Nevada". Closure must be protective of surface water as well as ground water.

See following page/s for continuation and cost summary

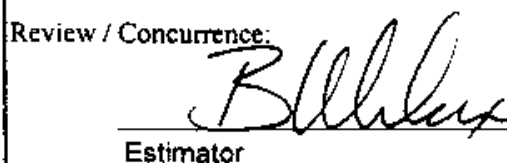




\section{BASIS OF ESTMATE cont:}

- The pond is bermed on all four sides with berms that are approximately 4 feet above surrounding playa surface with variable widths of 30-55 feet at the base of the berm and approximately 15 feet wide at the top based on surveyor maps.

- The bottom of the pond is approximately 4 feet lower in elevation than surrounding land surface based on surveyor maps and visual observation. A chain link fence currently surrounds pond berms.

- The top foot of material within the pond and the inside walls of the berms contains the majority of contamination.

- Closure of this site must be done in accordance with RCRA (hazardous waste) closure, which requires either clean closure or closure in place as a landfill.

\section{ASSUMPTIONS:}

NOTE: The following extimate assumes mixed waste soll will be accepted for disposal at pit 3 In Area 5 in burrito wrapped containers.

- Assume all waste will be mixed (i.e., low-level radioactive waste and hazardous waste). Approx. 1,000 cf of waste (pipe, concrete debris from sump, \& PPE) will be placed in B-25 boxes and transported to NTS Area 5 for disposal. One foot of soil from pond bottom and inside of berms (approx. 1,800 cy) will be excavated, placed in burrito lined end dump trucks, and transported to Area 5 for disposal. Each load will be weighed, certified, and documented.

- Proposed FY98 unit cost for mixed waste disposal at the NTS includes NTS Low Level Rad Waste fee (\$16/cf), State fee (\$26/ton), and BN recharge costs. Total cost is $\$ 35 / \mathrm{cf}$ ( $\$ 945 / \mathrm{cy})$.

- Assume workers will require full PPE and respirators for removal of pipe and sump debris. Equipment operators and other personnel required to work in the pond during excavation will also be required full protection. Continuous RCT support will be required during removal and excavation activities.

- Assume confirmation sampling and analysis of waste will be required for disposal. Assume confirmation sampling of soils surrounding sump and pipe will be required prior to backfill/ctosure.

- Assume BN will provide all engineering, craft labor, and equipment support for excavation activities and construction of the engineered cap. All labor costs are based on $10 \mathrm{hrs} /$ day, 4 days/week.

- Assume a cap model will be designed, constructed adjacent to the pond, and tested to insure that the cap will meet regulatory and design requirements. The final engineered cap will be based on the model design following testing and evaluation.

- Assume remaining berm soils will be pushed into the pond and will fill approximately $50 \%$ of the pond including compaction. Approx 7,700 cy of native, low-permeability material will be imported from the lake bed $1 / 2$ mile from the pond to complete the fill and construct the engineered cap.

- Assume native material available from Yucca playa will meet the requirements for a RCRA cap. (RCRA closure in place requires an engineered cap to be less permeable than the bottom of the unit.)

- Assume a low-permeability $2 \mathrm{ft}$ thcik cap (measuring approx $300^{\circ} \times 300^{\prime}$ ) will be constructed above the backfilled pond. The cap will be approx. $2 \mathrm{ft}$ higher than the existing playg at the center. BN will provide survey support to insure design specifications for engineered cap are met and to provide specifications for as-built drawings.

- Assumes playa material witl be excavated and transported using earth moving scrapers. 6 inches of Type II material (approx $1,800 \mathrm{cy}$ ) will be imported from the NTS Cement Plant and placed on top of low-permeability layer to protect cap from errosion.

- Water will be applied to the imported material for dust control and compaction. Assume water trucks and heavy equipment will compact playa and Type Il materials to $90 \%$.

- Assume 4 dump trucks with 18 cubic yard capacity will be used to import Type II from the NTS Cement Plant and baul waste to Area 5. Assume average speed is $35 \mathrm{mph}$. Distance is 10-15 miles one way for both activities. Cycle time for each truck is $8 \cdot 10$ loads per day.

- Assume existing chain-link fence will be removed for construction activities and re-installed at the same location on completion.

- Assume field work will be complete in 6 weeks. 


\section{ASSUMPTIONS cont:}

- Assumes no monitoring wells are required

- Assumes post-closure monitoring will consist of visual inspection and maintenance of the engineered cap.

- Assumes posi-ctosure monitoring to be monthly for the first year and quarteriy thereafter for at least nine more years (total ten years).

\section{CONTINGENCY:}

Contingency costs are not included in this estimare. All costs are in FY98 dollars.

COST SUMMARY - TOTAL ESTIMATED COST:

TEC - ENGINEERED CAP / TEST MODEL DESIGN

TEC - CLOSURE REPORT FIELD WORK

TEC - WASTE MANAGEMENT AND DISPOSAL - SUMP AND PIPE ONLY 


\section{Distribution List}

\section{Copies}

Paul J. Liebendorfer

2 (Controlled)

State of Nevada

Bureau of Federal Facilities

Division of Environmental Protection

333 W. Nye Lane, Room 138

Carson City, NV 89706-0851

Supervisor

1 (Controlled)

Bureau of Federal Facilities

Division of Environmental Protection

555 E. Washington, Suite 4300

Las Vegas, NV 89101

Sabrina D. Bonnell

1 (Controlled)

Environmental Restoration Division

DOE/Nevada Operations Office

P.O. Box 98518, M/S 505

Las Vegas, NV 89193-8518

Allison Urbon

Bechtel Nevada

1 (Uncontrolled)

P.O. Box $98521, \mathrm{M} / \mathrm{S}$ NTS306

Las Vegas, NV 89193-8521

Steve Nacht

1 (Uncontrolled)

Bechtel Nevada

P.O. Box 98521, M/S NTS306

Las Vegas, NV 89193-8521

Janet Appenzeller-Wing

1 (Uncontrolled)

Environmental Restoration Division

DOE/Nevada Operations Office

P.O. Box 98518 , M/S 505

Las Vegas, NV 89193-8518 


\section{Copies}

Sabine Curtis

1 (Uncontrolled)

Environmental Restoration Division

DOE/Nevada Operations Office

P.O. Box 98518, M/S 505

Las Vegas, NV 89193-8518

Ken Beach

1 (Uncontrolled)

IT Corporation

P.O. Box 93838

Las Vegas, NV 89193

Mary Todd

1 (Uncontrolled)

IT Corporation

P.O. Box 93838

Las Vegas, NV 89193

IT Corporation Central Files

1 (Uncontrolled)

IT Corporation

P.O. Box 93838

Las Vegas, NV 89193 